Historic, Archive Document

Do not assume content reflects current scientific knowledge, policies, or practices. 



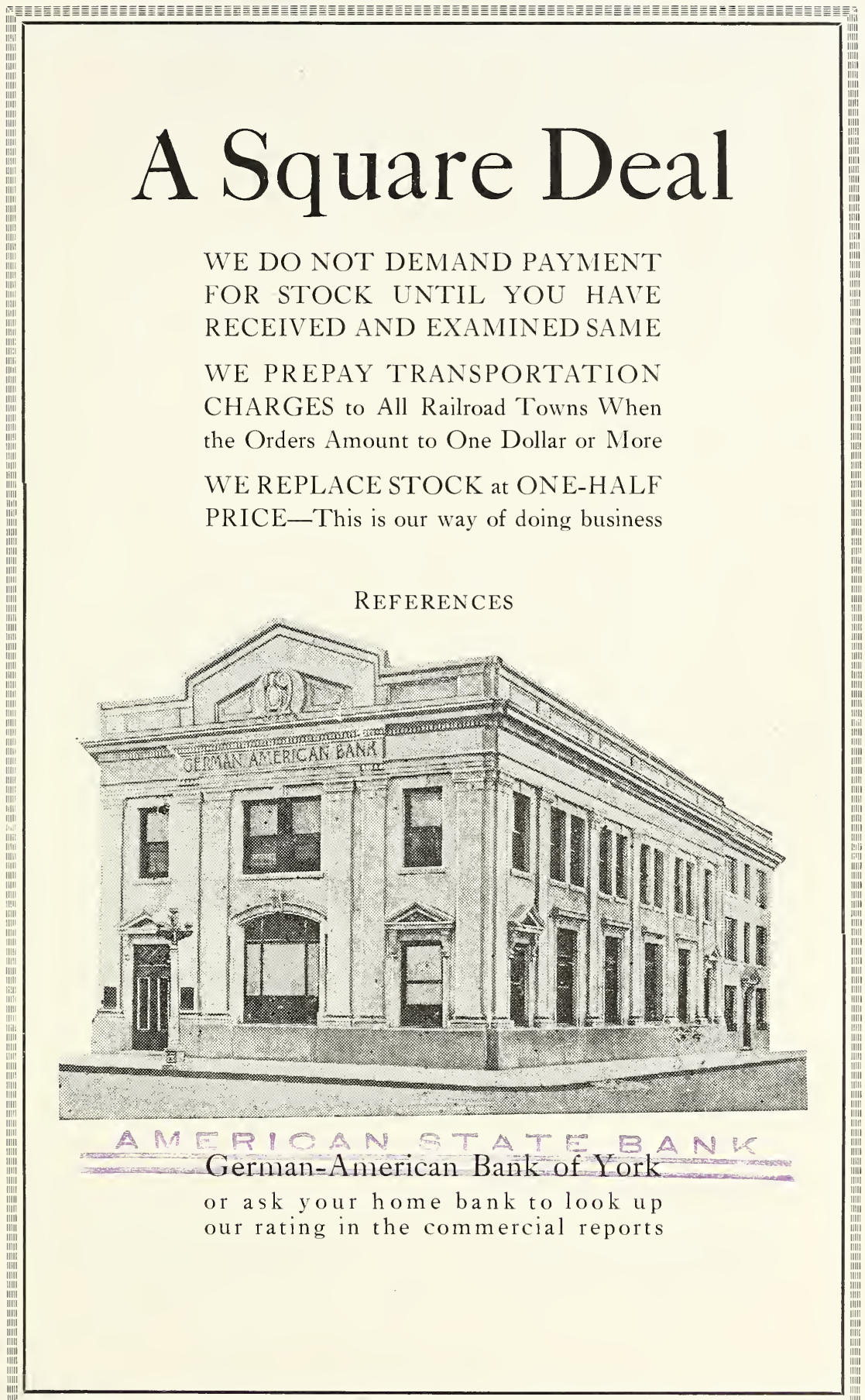

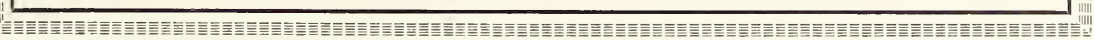




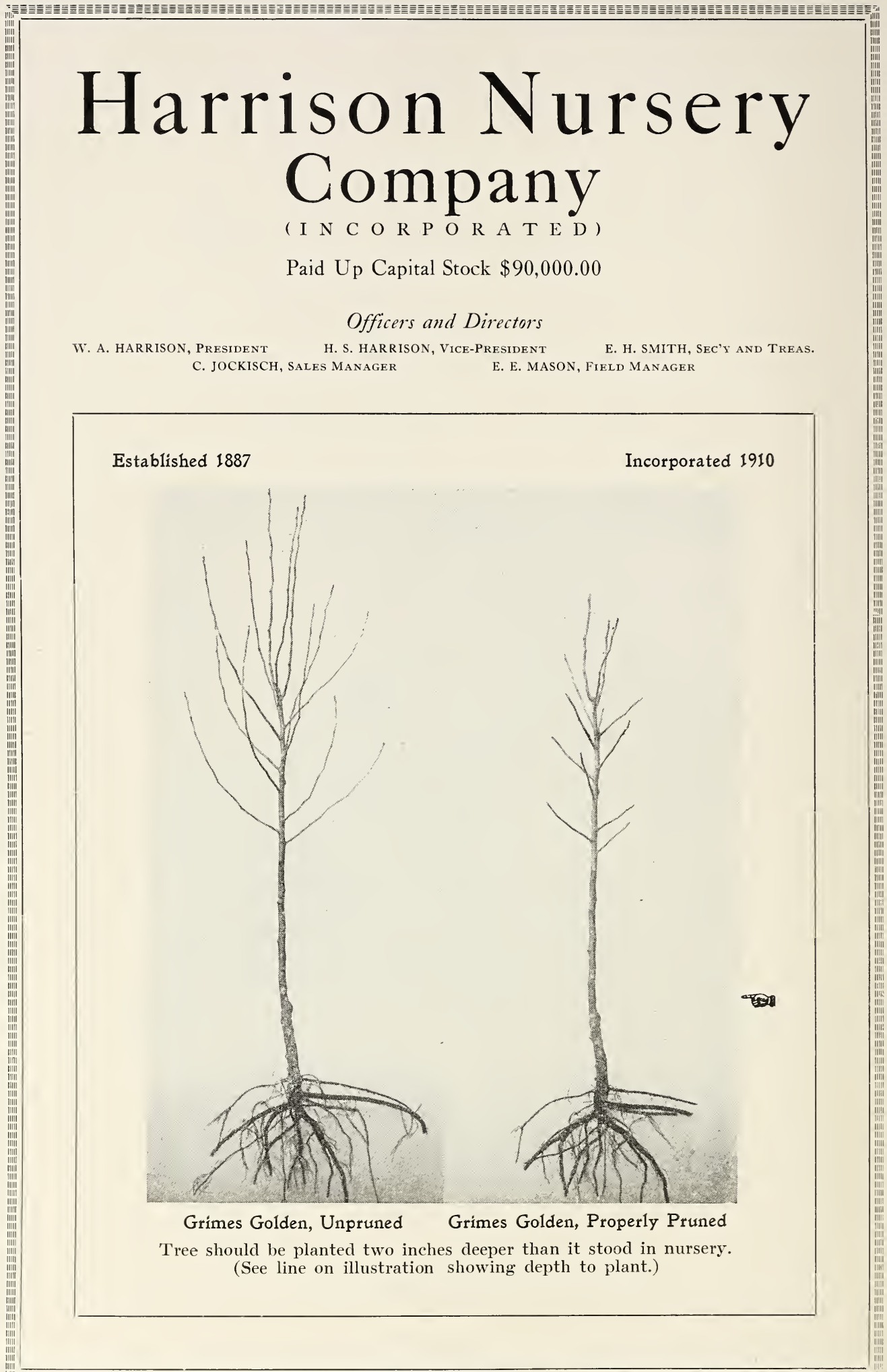




\section{SALUTATION}

In offering our catalog we extend thanks to the public for past courtesies, with assurance that we shall continue to spare to effort in furnishing superior quality and service. If we have never serred you, send us a trial ordei. We desire to prove to you that knowing how to take care of your order is not an inspiration, but is knowledge gained by long experience. If you are already one of our patrons, you are aware of our keen interest to please you and we rest assured to your mind our treatmezt merits continued consideration.

\section{A TALE}

Over twenty-five rears ago, the Harrison Brothers started the Harrison Nursery at York. The most of Nebraska at that time, was a treeless plain. The idea of raising a stick of timber sufficiently large to make a fence post seemed preposterous. The very thought of growing fruit was considered ridiculous. The general impression prevailed that the country was adapted only to the production of corn and hogs. The obstacles that confronted the young men seemed almost insurmountable. They had no capital. The adrice of all friends and acquaintances was against the project, but they had as assets, routh, hope and the genius of labor coupled with a prophetic faith in the ultimate greatness of Nebraska. For a number of years every tree was grafted, planted, trimmed, hoed, cultivated, dug out of the ground with a spade, graded, tied up and labelled by the firm. In fact you might say this first excursion in the realm of experimental horticulture was personally conducted - no one but a proprietor officiating.

The demand for Nebraska-grown stock became so great it was found necessary to enlarge the nursery field, packing rooms, cellars, and to erect a modern office structure. It was also found necessary to add more timber to the managing force, and to reorganize the company in order to accommodate the large volume of business, consequently in the spring of 1910, the company was incorporated under the laws of the State of Nebraska for $\$ 100,000.00$, with a fully paid-up capital stock of $\$ 73,700.00$. E. H. Smith, a Nebraska-grown product, who had formerly been employed by the Burlington Railroad for sixteen vears in the operating and traffic departments, became a director and was elected secretary and treasurer. E. E. Mascn, another Nebraska boy, who had been employed by the Harrison Brothers since fifteen vears of age, also became a director and was made superintendent of the nursery farm. In order to enlist the permanent assistance and support of employes, sereral of the field and office men and women were given an opportunity to become stockholders.

Note the change in a quarter of a century. York can today boast of one of the largest retail nurseries in the West, comprising over 275 acres. Where grafts and trees were originally planted by hand, they are now put in by a machine with a capacity of planting as many as 80,000 trees a day. Instead of chopping them of with a spade, they are dug with an enormous tree digger, operated by ten horses and every root and rootlet is preserved. In the early dars the stock was served to patrons by wagon. Now the shipping business is so enormous that the Burlington people send extra men during the month of April to take care of this extra business. Work that was once done by two partners is now giving employment to dozens of men.

The Harrison Nurse:y Co. has one of the most complete packing houses in the West. Trees are hauled immediately from the field and graded and handled in a frost and heat-proof building, with a capacity of 450,000 cubic feet. They have a most thorough and complete packing system. To make a mistake in filling an order is almost impossible.

This little tale relating to Nebraska-grown trees and Nebraska-grown men, is to call your attention to this proposition: The average tree planter knows little about trees, their culture and adaptability of variety to locality. Hence you must rely greatly on your nurseryman for advice and counsel. Horticulture requires technical knowledge, and the man who comes up from the stubble has acquired the fundamental principles which enables him to give the most practical advice. Harrison Brothers do not want to be considered as deprecating a book-learned education, because they have been students of horticultural works and magazines all their lives, but sometinies you read a thing and forget; but when you have been up against the real experience, then you know something permanently.

The Harrison Brothers know a few things about trees, for they have learned from actual experience. They have had black lines under their finger nails, and know something about soil. They hare a large experimental orchard and hare thoroughly tested hundreds of rarieties, and they can tell rou about some kinds that you ought not to plant, which is something. They have traveled all over Nebraska and Western states for vears, and by constant observation they have discovered a great variety of conditions, in different parts of the country. They are always ready and willing to give their patrons the benefit of their experience and observation.

\section{LOCATION}

We want, right at this point, to lay stress on one fact, and that is that the Harrison Nursery Co. is located at YORK. We make this emphatic because we are proud of York, and we hope York is somewhat proud of us. York, you know, is noted for its citizenship, its thrift and progressiveness, and especially for its beautiful homes and well-kept lawns, and here the nursery influence can be seen, because there are more distinct species of different ornamentals in York than in any other town in the state. It is a well-known fact that York is located in one of the richest agricultural districts of the Lnited States. York is located on a system of railroads that give excellent service to all parts of the country. Express is handled by two of the leading express companies and prompt service is assured. 


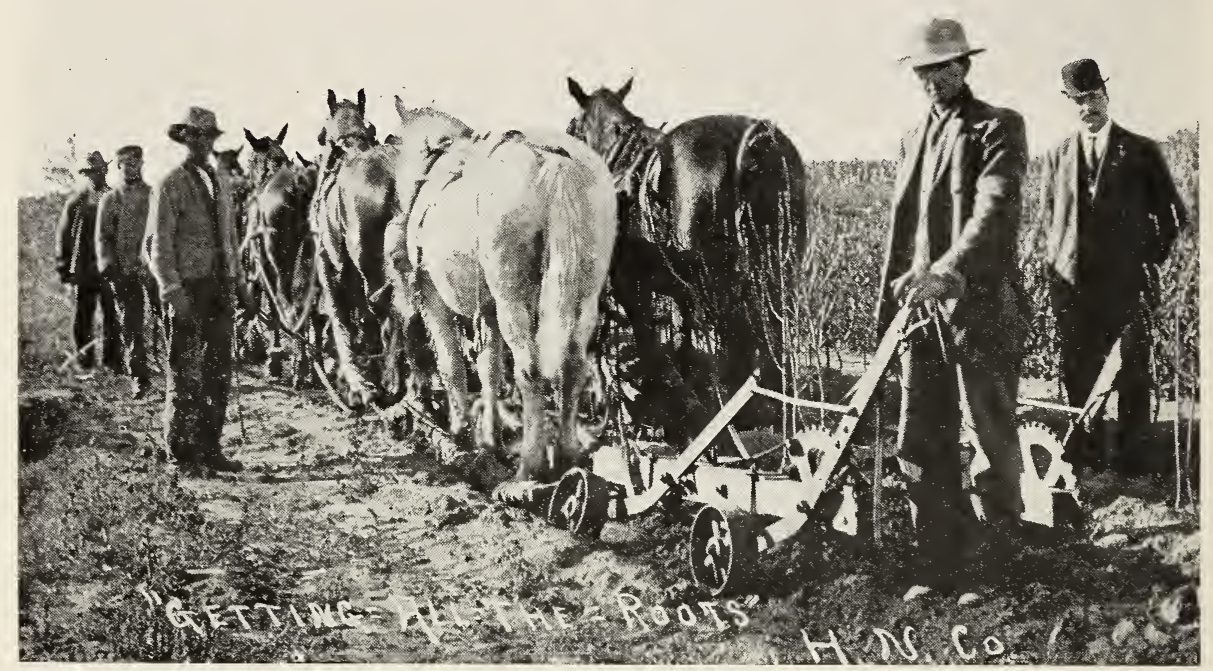

TREES GROWN ON HIGH GROUND

The Harrison Nursery Co. field is located on a high divide, with no creek bottoms, river bottoms or low lands to force the growth of their nursery stock. It is just as essential to select nursery stock from high, dry ground, as it is seed corn. The soil is peculiarly adapted to the successful growth of trees, giving them a strong, vigorous root system and a well-developed, symmetrical body.

\section{QUALITY}

All stock grown by the Harrison Nursery Co. is graded by caliper and height, and everything not up to the standard is consigned to the brush pile and burned. The caliper proves the physical condition of a tree. For instance, a tree may be 5 to 6 feet in height and caliper $1 / 2$ inch, or on the other hand may measure 3 to 4 feet in height and caliper $3 / 4$ inch. In either case the tree is not in a healthy condition for planting. The tree family may rightly be compared with the human family. For instance, a man may measure 6 feet in height and weigh 100 pounds, or on the cther hand he may be 5 feet tall and weigh 300 pounds. You will concede in either case the man is not in a normal condition. Thus you will see the importance of properly grading nursery stock; it costs us more to grade the stock, but we believe in giving our customers the best that can be had, regardless of expense. Quality is considered above all things else, and the demand for such is constantly increasing. People are beginning to realize the importance of planting good trees for permanent improvements, instead of planting a cottonwood in the front yard, as did the early settlers, a nice hardy ornamental tree is selected. Instead of planting a cheap whip cherry tree or apple tree in the back yard, first-class graded trees are used. Instead of using the swine to mow the grass in the front yard, a lawn mower is used with great care to insure the safety of the flowering shrubbery and roses which adorn the home.

\section{PRICES}

Just a word in regard to prices. Those wishing cheap trees at a cheap price will waste both their time and ours. We put out to our trade nothing but first-class trees, at reasonable price. We do not intend to compete with cheap catalog nurseries in foreign states. A row of trees is made up of many grades. We want our customers to get the best and the other fellow the culls. You are rery foolish to hesitate over the small difference in price between a good and an indifferent tree. If you were to go to your neighbor's to buy some hogs, would you pick out the runts because they happened to be a few cents cheaper? No; you would pick the choicest and pay the price, because you realize they would be cheaper in the end. Do not get the impression, however, that we are high-priced. We guarantee to compete with anyone, both in price and quality. We simply refuse to sell the trade inferior trees at any price. "Good goods at honest prices," is our motto. We have built up what reputation we have on that platform, and we intend to adhere to this rule to the end.

\section{INSPECTION}

Our nursery is inspected each year by the State Entomologist, and a certificate issued by him showing stock to be free from San Jose scale and insect pests, and to be in a healthy condition, is attached to each shipment.

\section{GUARANTEE OF GENUINENESS}

While we exercise the utmost diligence and care to have varieties true to name, and stand ready at all times on proper proof, to replace all stock that may prove otherwise, or refund the amount paid, it is mutually understood and agreed between purchaser and ourselves that we shall in no case be liable for any sum greater than the amount originally received for said trees, etc., that prove untrue. 


\section{NOTICE}

Our patrons are requested to read carefully "Hints on Transplanting," "The Preparation of the Soil," "Preparing Trees for Planting," "After Culture." The information under these headings is important, and success in planting will largely depend upon the careful observation of the suggestions made.

\section{CLAIMS}

for errors should be made promptly on receipt of goods, as we cannot recticy them unless promptly made.

\section{REMITTANCES}

In remitting please use Bank Draft, Express Money Order, or Postoffice Money Order. If check is used add for exchange.

\section{GENERAL INSTRUGTIONS FOR TRANSPLANTING AND MANAGING FRUIT TREES}

1. PREPARING THE GROUND-Before planting fruit trees the soil (except new ground), should be made mellow by repeated plowing, and where the soil is densely packed, a sub-soil plow should be used and the ground stirred up from twelve to fifteen inches deep. If this is neglected the roots are soon surrounded by an almost impenetrable wall and cannot be expected to live many years. Whenever this system has been practiced, healthy and vigorous trees and fine fruit have been the result.

2. RECEIVING AND CARING FOR TREES-Trees are frequently ruined through the lack of care or bad management after they fall into the hands of the purchaser. When trees are received the roots should be covered with a blanket, sack or straw until they reach their destination. The bundle should then be opened and the trees separated from the moss in which they are packed. If the roots have become dry from long exposure, straw should be spread upon the ground, the trees laid upon it, then covered entirely (roots and tops) with straw and the whole well watered. If holes are not yet dug or the ground too wet to plant when the trees are received, dig a trench and lay the trees in a slanting position, so that you can cover up the roots and two-thirds of the body or stalk. In this position let them remain until the holes are dug or the ground is in a suitable condition to receive them.

3. DIGGING THE HOLES - If the soil for an orchard has been properly prepared by sub-soiling and deep plowing, then the opening of the holes becomes a very simple matter, and really this is by far the easiest, cheapest and best plan; for if the soil is thoroughly pulverized to a depth of from twelve to fourteen inches, all that is necessary is to measure off the distance at which the trees shall stand from one to another and the order of planting. Where only a few trees are to be planted and the soil has not been sub-soiled, or where the trees are to be planted in sod, then the holes ought to be at least four feet wide and eighteen to twenty inches deep, the sub-soil thrown back and the hole filled up to the proper depth with fine top soil to receive the trees.

4. PRUNE BEFORE PLANTING-Both root and top should be pruned at time of planting and before the tree is set in the ground. First cut off the ends of broken and bruised roots with a sharp knife, in a slanting direction on the under side. This will cause the wound to heal over readily, by throwing out plenty of fibrous root at the end. Then cut back each branch or side limb to a bud not more than four to six inches from the body. Then cut back the leader or central limb so as to leave it about four or five inches above the highest side limb. When there are no side limbs the tree should be headed back to a height proper to form a top. None of the lower limbs should be cut off entirely, as it is best to form the heads as low as possible, so that the limbs and leaves will protect the trunk from the direct rays of the sun.

5. DEPTH TO PLANT-Immense numbers of trees are ruined by being planted too deep. Most kinds of fruit trees, except dwarf pears and plums on peach and quince roots, should be planted not over two or three inches deeper than they grow in the nursery row. Dwarf pcars and plums on peach and quince roots should be set so that the joint where the body and roots are united will be about four inches below the top of the ground. By this means roots will be thrown out from the body that is covered and larger and longer lived trees secured.

6. PLANTING WITH DYNAMITE-We recommend the use of dynamite to erery planter of trees. It is the up-to-date way of planting all kinds of trees.

1st. It is more economical than any other method.

2nd. It costs little if any more than digging a proper sized hole with the spade.

3rd. Dynamiting the soil conserves moisture and prevents the big losses during dry seasons that are common with spade-dug holes.

4th. Trees planted with dynamite make as much growth in two years as spade-set trees will in four years. 
5̆th. Dynamite breaiks up the ground for 12 to 15 feet in diameter and 5 to 6 feet deep, kills all insects and fungous growth contained in the soil. longer.

6th. Dynamite-set trees bear fruit from one to two years sooner than spade-set trees, and live

Write to the E. I. Du Pont Nemours Powder Co., Wilmington, Delaware, and ask them to send you their "Instruction Book" on "Tree Planting" with dynamite.

7. PLANTING--When ready to plant, take from the trench a few trees at a time; place the tree in position and arrange it to the proper depth by filling in or raking back the soil to or from where the tree will stand; then fill in the fine mellow soil between and around the roots with the hand, arranging the roots in their natural position and packing the soil carefully around them. When the roots are barely covered, sprinkle on water to moisten the soil and settle it among the roots; then fill to the top, press the earth rery firm around the tree with the foot as you fill in. Throw a bucket of water around each tree to settle the ground, and scatter a little soil on to prevent baking.

8. MULCHING-Mulching prevents the moisture from escaping and maintains equitable temperature about the roots. The material used may be long manure, litter, straw, grass or hay, which should be spread on the surface around the tree for the space of four or fire feet and three to six inches deep. Bearing trees may be benefited by mulching heavily in winter, which will tend to preveat an early derelopment of the fruit buds and assist them to escape the effect of late frosts.

9. AFTER CULTURE-The trees should be kept free from grass and weeds, and no crops should be grown in the orchard while the trees are young, except such as can be cultivated with the plow or hoe. Cultivate well in the spring and summer.

10. AFTER PRENING-The great majority of people do not take proper care of their trees after planting. This is a great mistake. If a tree or vine does not receive the right kind of care and enough of it when young, it will never attain a healthy old age. Very much has been said about pruning by various authors. Judging these and our own experience and observation, we would say: The best time to prune fruit trees, and about all kinds of trees and shrubs, is during May and June, May preferred; but be governed by the health and vigor of the tree. We do not advise serere pruning, as too much would injure the tree. Keep all superfluous forks and limbs cut off and the heads in proper shape to admit air and sunshine as long as the tree lives. Currants and Gooseberries should be trimmed late in the fall or early in the spring, before commencing to grow; Grape vines late in November or any time during the winter up to March 1st; after this trimming is apt to excite bleeding or flowing of sap from the wounds. If desirous of getting rubbish removed from the orchard during the winter, cut limbs off eight to ten inches from the body and cut balance off May or Jnze following.

\section{A TABLE SHOWING THE NUMBER OF TREES OR PLANTS TO THE ACRE}

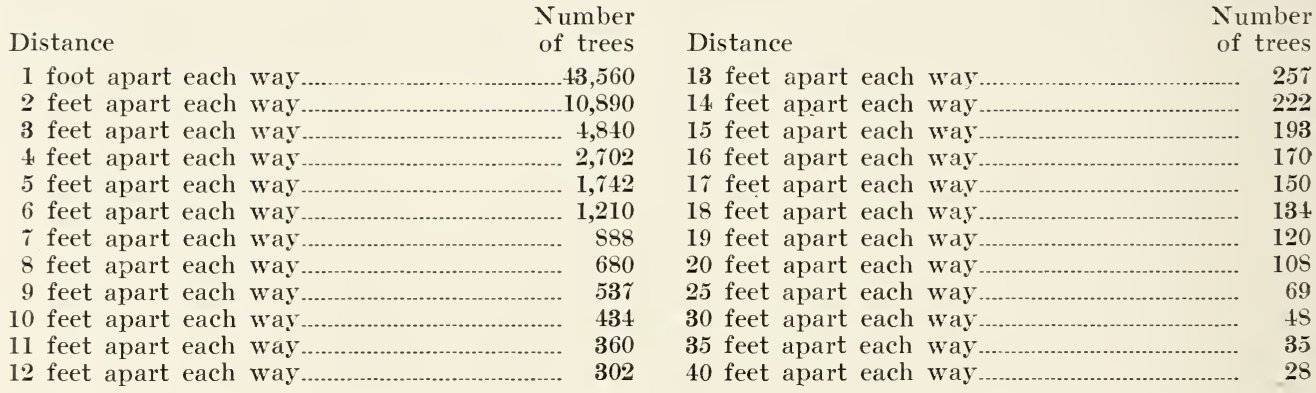

RULE-Mulitply the distance in feet between the rows by the distance the plants are apart in the rows, and the product wili be the number of square feet for each plant or hill, which, divided into the number of feet in an acre $(43,560)$, will give the number of plants or trees to the acre.

\section{SUITABLE DISTANCES FOR PLANTING}

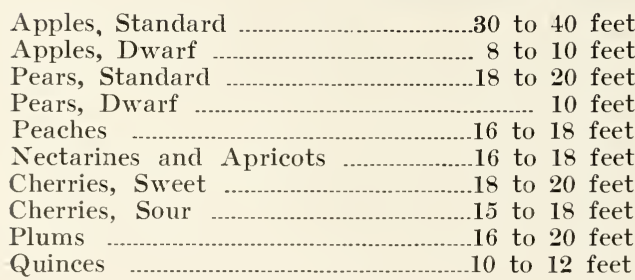

Grapes

Currants

Gooseberries

Raspberries, Red

Raspberries, Black

Blackberries

Strawberries, rows

Strawberries, in beds

Asparagus, in beds

Asparagus, in field
S to 10 feet 3 to 4 feet 3 to 4 feet 3 to 4 feet 4 to 5 feet 5 to 7 feet by $3^{1 / 2}$ feet $1 / 2$ by $1 \frac{1 / 2}{2}$ feet by $1 \frac{1}{2}$ feet by 3 feet 


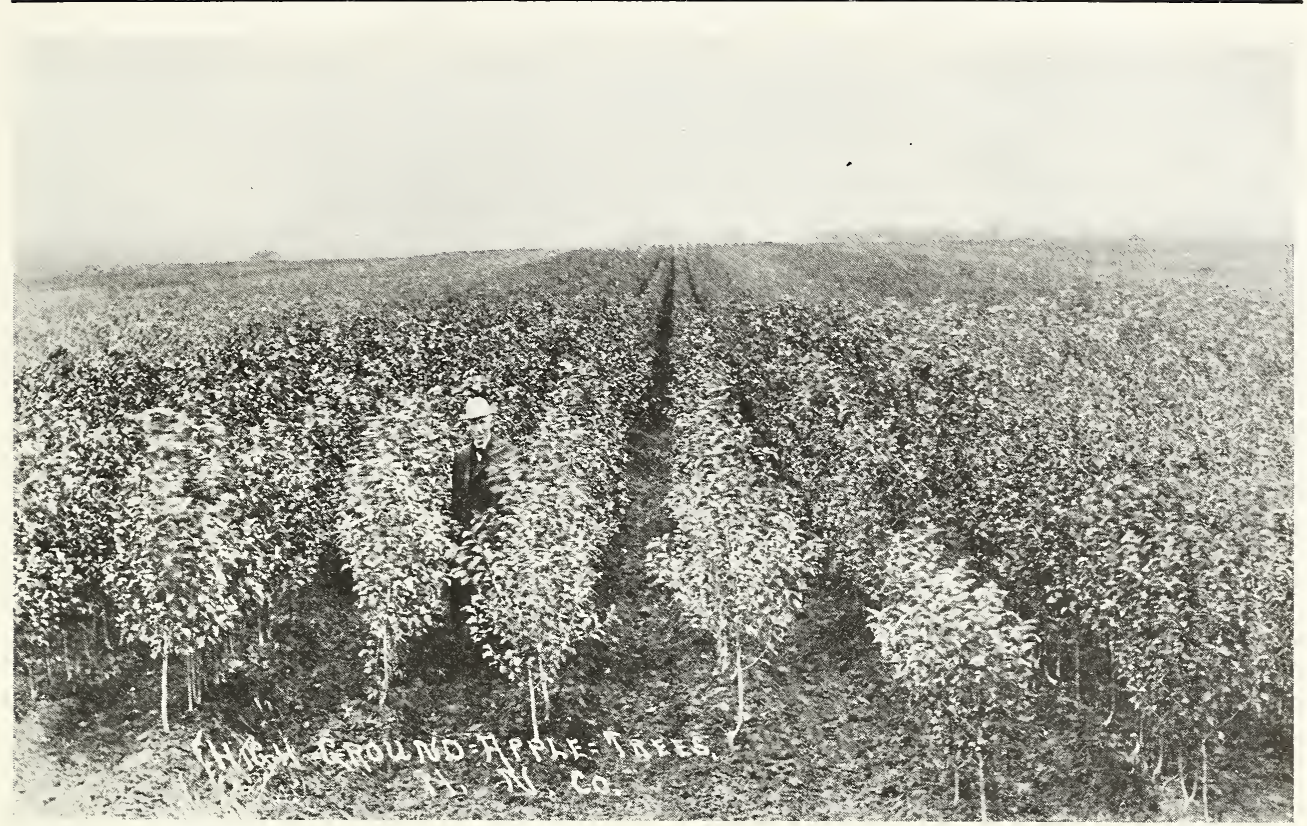

\section{Fruit Department}

\section{Apples}

The apple is the first in importance of all fruits. It will thrive on nearly any well-drained soil. Its period of ripening, unlike other fruits, extends nearly through the whole year. By making careful selection, a constant succession can be obtained. For family use there is no fruit that is more incispensable. No fruit is so healthful and many physicians say that if a person would eat an apple a day they could dispense with doctor bills. Besides this, and just as important, is the fact that the arerage price on the market is steadily increasing and the immense demand for home consumption, foreign shipping, canning and evaporating assures high prices. The apple if given the same care and attention as other farm crops, will yield greater returns per acre. The following list we consider to be the best.

\section{WINTER APPLES}

Arkansas Black. A remarkably handsome crimson-black apple; large, perfectly smooth, roundish flat, lightly dotted with white, the flesh is yellow, juicy and delicious, keeping late. December to April.

Baldwin. Origin, Massachusetts. Season, December to March. The great commercial late winter keeper of the Eastern states. Tree a vigorous, open grower, upright in tendency and very productive where hardy. Fruit large, rounded, deep red; flesh rich, crisp and juicy.

Banana. Fine vigorous grower, large healthy foliage; early bearer. Fruit medium to large, smooth and handsome, golden yellow usually shaded with red blush; flesh fine grained, rich, subacid, aromatic; highest quality. One of the best dessert apples. A valuable market variety in some sections. Originated in Indiana.

Ben Davis. Origin, Kentucky. Season, January to April. Vies with Baldwin as a profitable commercial variety in many sections; quality not so good, but a better bearer and keeper. Tree very vigorous and hardy in the Central States. Fruit large, handsome, brightly striped with red; flesh medium quality.

Black Ben Davis. So nearly like Gano in every respect that it needs no further description.

Delicious. Fruit is large, with the surface almost covered with a most beautiful, brilliant dark red, blending to golden yellow at the blossom end. In quality it is unsurpassed, in flavor sweet, slightly touched with acid, but only enough so as to make it all the more pleasing, with an aroma delightfully fragrant. The flesh is fine grained, crisp, juicy, melting and withal delicious. In keeping quality it ranks with the best, coming out of storage in March and April in perfect condition. Tree is very hardy. We advise all our customers in the Middle West to plant Delicious. You will never regret it. No better apple exists. It is no more an untried novelty, but has been largely planted in the Middle West and Pacific states. Commercial orchardists plant them by the thousand. 
Gano. Originated in Missouri. Similar but superior to Ben Daris. It has all the good qualities in a higher degree, more brilliant coloring, runs more eren in size, and keeps fully as late. The tree is vigorous and hardy; is a rapid grower; bears while young. Color bright red without stripes or blotches, and large and even in size. Season, February to March.

Grimes' Golden. Origin, Virginia. Season, November to January. Tree rigorous, upright, spreading, a good early annual bearer. Fruit above medium, regular; surface rich golden yellow, sometimes with net veining of russet; flesh yellow, firm, compact, crisp, aromatic, rich, spicy, sub-acid; quality the best. A valuable early winter apple and particularly desirable for its late blooming.

Hibernal (Northwestern Ironclad). Origin, Russia. Season, November and December. This variety represents what is probably the hardiest type of the Russian race. Tree sturdy, vigorous, very spreading and productive. Fruit large to very large, irregular; greenish yellow with dull bronze red on sunny side; flesh acid, juicy, very good for cooking. Succeeds in the most exposed locations and is popular in the Northwest on this account.

Hubbardston Nonsuch. Large, handsome, yellow, overlaid with red; tender fleshed, with distinct, delightful flavor. Strong grower and heavy bearer. A native of

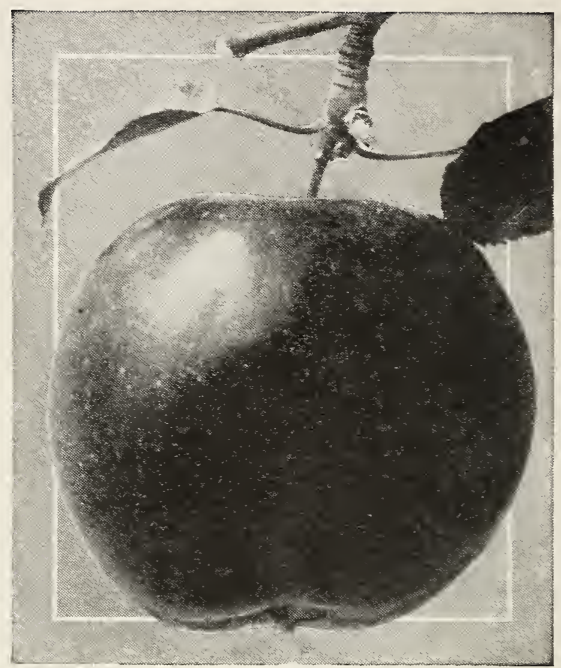

Jonathan Hubbardston, Massachusetts. November to January.

Ingram. A seedling of Janet. Tree more up- low with bright mottled red blush. Flesh white, right and a better grower. Fruit medium size, roundish, inclined to conical; smooth, yellow ground, striped, bright red, flesh greenish-yellow, delicate, tender, juicy, sub-acid. A late keeper.

Iowa Blush. Origin, Iowa. Tree very productive; a strong grower in nursery and orchard. Fruit small, roundish conical; surface smooth, yel-

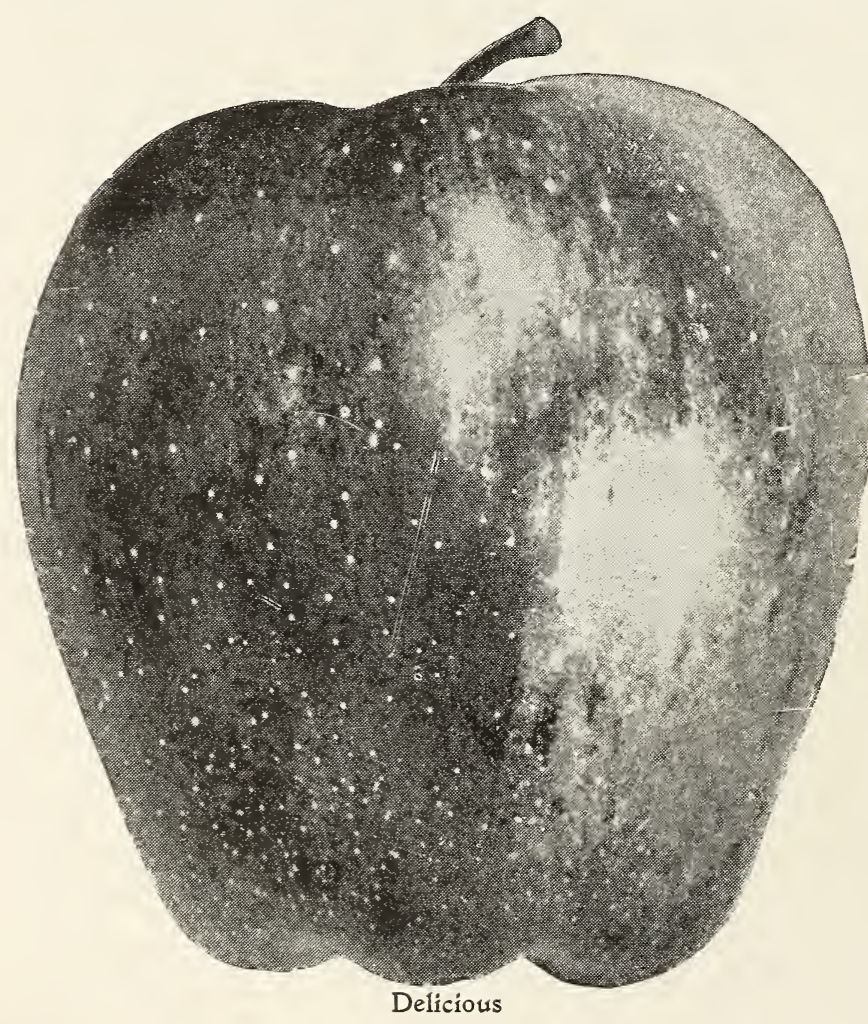

Janet (Rawl's Neverfail). Medium in size, roundish, approaching oblong or obtuse-conical, often oblique; color pale red, distinct stripes on light yellow ground; flesh nearly white, fine, mild, sub-acid, fine texture, crisp, juicy. Growth slow; a profuse bearer. Keeps through spring. The blossoms open ten days later than usual kinds, thus sometimes escaping spring frosts, and hence the name Neverfail.

Jonathan. Origin, New York. Season, November to January. A seedling of Spitzenburg, which it resembles in fruit, and is a much better tree. Hardy in latitude of Central Iowa, where it is a rigorous and productive rariety. A delicious and strictly dessert apple tinat always commands the highest market prices. Fruit of good size, roundish; surface is very smooth, clear light yellow, almost corered with rich dark red on sunny side; flesh white, tender, juicy, spicy, aromatic.

Mammoth Black Twig. Excels Winesap in nearly every important point; a better grower, hardier, and the fruit much larger; color even a darker red; flesh firmer; flavor is milder, but fully equal. A long keeper.

McIntosh Red. Origin, Ontario. Season, December and January. A choice variety of the Fameuse type. Tree vigorous with spreading head; a good anmual bearer. Fruit above medium to large, highly perfumed; smooth polished yellow, almost covered with brilliant solid crimson, a beautiful fruit; flesh snow white, crisp, very tender, sprightly aromatic, sub-acid; very good quality.

An apple a day will keep the Doctor away 
Missouri Pippin. Large, oblong, bright red with numerous gray dots, very handsome and of fair quality, an early and very abundant bearer, and very profitable orchard fruit; vigorous. December to March.

Northern Spy. Large, roundish conical, often flattened, slightly ribbed; handsomely striped with red; flavor rich, aromatic, mild sub-acid, fine. Keeps through winter and late into spring; a taray bearer. To afford fine fruit, tree must be kept thrifty by good cultivation. A fruit of the highest quality, and profitable for market.

Northwestern Greening. Origin, Wisconsin. Season, December to March. Tree a splendid, vigorous grower, quite hardy. Fruit large to very large; green, becoming yellowish green when ripe; flesh yellow, fine grained and firm; flavor a good sub-acid; very smooth and attractive; should be given plenty of room in the orchard to secure large, even fruit. One of the best growers we have in the nursery and in the orchard, is very prolific and regular when mature.

Patten's Greening (Northwestern Ironclad). Origin, Iowa. Introduced by C. G. Patten. Season, October to December. A seedling of Duchess of Oldenburg. Fruit large to very large, when well grown; green with often a blush of red or brown; flesh yellowish white, rather coarse, but firm; core small; flavor a pleasant acid. Tree vigorous and spreading, and exceptionally hardy; an early and regular bearer. The fruit is very smooth and attractive and keeps well in home orchard and for market and is highly recommended for general planting.

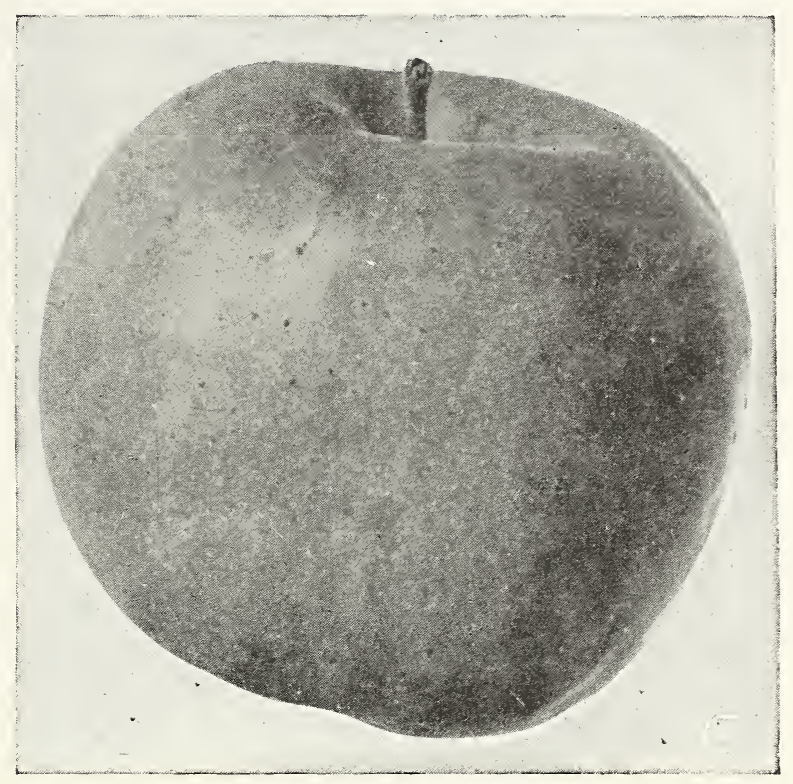

Northwestern Greening

Rome Beauty. Large, roundish, very slightly conical; mostly covered with bright red on pale yellow ground; flesh tender, not fine grained, juicy, of good quality. Ripens early in winter. The large size and beautiful appearance of this Ohio apple render it popular as an orchard variety.

Salome (Northwestern Ironclad). Flesh whitishyellow, half fine, tender, mild, slightly aromatic, very good; January to May. Its hardiness, long keeping, good quality, uniform size, retention of its flavor quite late, makes it valuable for the West and Northwest.

Senator. A very beautiful apple. Smooth, red, flesh white, sometimes faintly pink. Took first premium at the Denver Apple Show in 1910.

Stayman's Winesap. It is now attracting attention everywhere as a profitable market variety. It has large size, bright red color, great productiveness and best quality to commend it. The tree is a vigorous grower and, like its parent, is irrigular and drooping in habit, and adapts itself readily to different soils and situations. Season, November to February.

Walbridge, Medium size, striped with red, good cooking; vigorous grower and productive; rery hardy and considered of value in the North and Northwest. December to January.

White Winter Pearmain. Rather large, conical, angular or ribbed; light yellowish green, with a brownish-red cheek; stem short; flesh whitish, fine grained, with a mild sub-acid, rich, fine flavor. Is one of the best and most productive winter apples in the West.

Order a few of the Northwestern Ironclad Apples. 


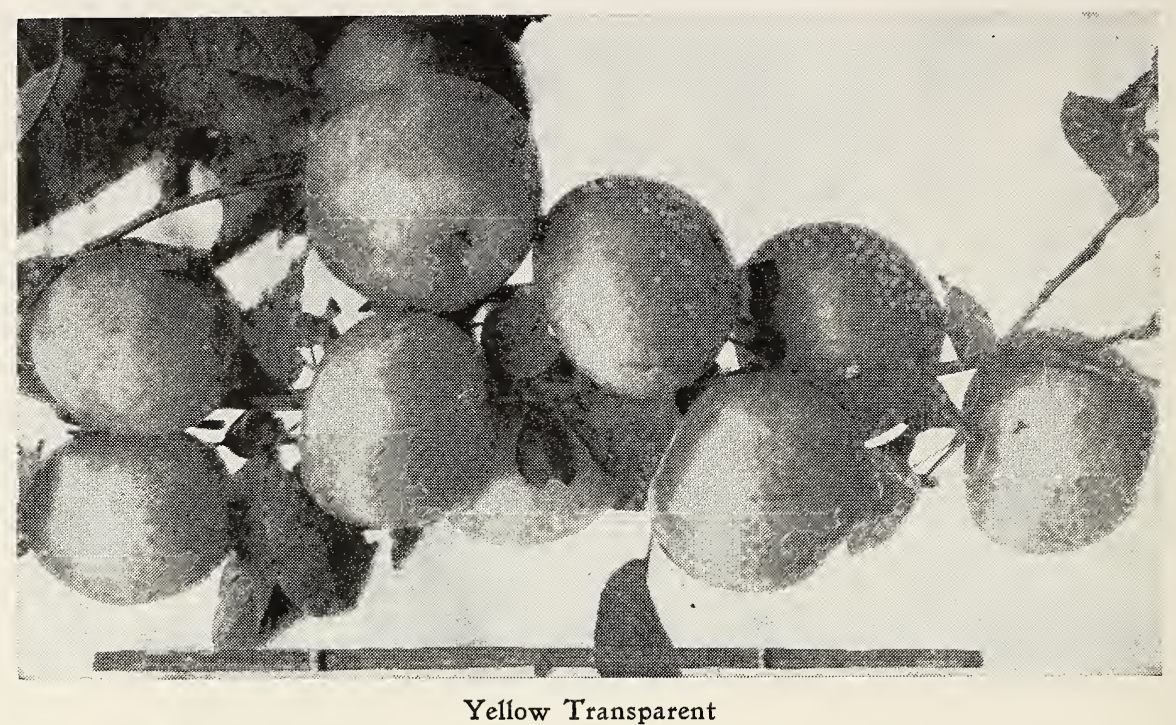

Windsor ...(Northwestern Ironclad (Windsor Chief). Medium to large; greenish yellow, suffused with red splashes, becoming quite red when ripe; gray dots, flesh pale yellow, sometimes streaked with red; fine grained, juicy, sub-acid, quality excellent. Tree an upright, moderate grower, becoming stronger as it attains age. Early annual bearer; very prolific. Winter. Originated in Wisconsin.

Winesap. Origin, New Jersey. A valuable, old, well-known variety. Season, December to May. One of the leading export apples. Fruit medium, roundish, skin moderately thick and very tough; dark yellow, almost entirely covered with dark red; flesh yellow, fine grained, firm, rich, crisp, sprightly sub-acid; quality excellent. Moderately vigorous; rather open, irregular head. Very productive; an early bearer.

Wolf River. Origin, Wisconsin. Season, October to January. One of the largest apples grown. Color yellowish-green with stripes and splashes of carmine, very handsome and showy; flesh nearly white, firm and rather coarse grained; flavor subacid, fair to good. Tree vigorous, fairly productive.

York Imperial (Johnston's Fine Winter). Origin, Pennsylvania. Medium, oblong, angular, oblique, smooth; yellow, shaded red, indistinct red stripes; flesh yellow, firm, juicy, sub-acid, good. Winter. An excellent shipper; brings high prices.

\section{AUTUMN APPLES}

Chenango Strawberry. Rather large, oblongconic, angular; striped and splashed with light crimson on whitish-yellow ground; cavity, narrow and deep; basin narrow; flesh white, very tender, with a pleasant, mild, sub-acid flavor. September and October.

Fameuse (Snow Apple). Origin, Canada. Season, October and November. An old and wellknow variety. Tree a moderate grower, productive. Fruit medium in size; color pale greenish-yellow, mixed with stripes of red, with splashes of same on shady side; flesh white, tender and juicy, slightly perfumed; flavor sub-acid, extra good.
Maiden Blush. Of uniformly good size, smooth, round, beautifully flushed with red on creamy yellow ground; flesh tender, of pleasant but not high flavor. A good market sort because of its attractiveness and the tree's heavy crops. September and October.

Peerless (Northwestern Ironclad). Origin, Minnesota. Season, September to October. Fruit is medium to large; yellowish-green with stripes and splashes of carmine; flesh yellowish-white; fine grained; flavor agreealle sub-acid, but not rich. Tree a vigorous, upright grower.

Price's Sweet. Of very strong, upright growth in nursery and orchard. Popular in parts of the West. Fruit medium, regular, oblong, conical, often unequal; surface yellowish-green, mostly thinly covered with mixed and marbled dull red, obscurely splashed and striped; dots, large, distinct, numerous, russet, rough; flesh yellowish-white, moderately juicy, very sweet, good. October to November.

Rambo. Size medium, oblate, smooth; streaked and marbled with dull yellowish red on pale yellowish ground; dots large, whitish; flesh tender, rich, mild sub-acid, fine flavored, often excellent. Late autumn and early winter.

Utter (Utter's Red). Origin, Wisconsin; a vigorous, upright grower. Season, September to October. Fruit above medium to large; surface yellow, splashed, mottled, striped and much dotted with bright red. Flesh white, fine grained, tender, juicy, mild pleasant sub-acid

Wealthy. Originated about 1861 by the late Peter M. Gideon, Excelsior, Minn. This one variety is an enduring monument for its originator. Season, September to January. Almost too well known to need description. Since its origination it has become extensively planted in all the apple growing states. Fruit large, regular, smooth, light yellow with crimson stripes and splashes; flesh white, often stained with red, tender, very juicy, sprightly sub-acid with delicious aroma. Splendid dessert and cooking apple. Market demand never supplied. 


\section{SUMIMER APPLES}

Duchess (Duchess of Oldenburg). Origin, Russia. Season, July and August. Tree upright, vigorous and extremely hardy. An early and annual bearer of uniformly large crop. Fruit large, greenish-yellow, with red stripes. Flesh light yellow, medium fine grained, firm; flavor a pleasant acid; a great cooking favorite and prime market sort. A good shipper for an early apple and commands good prices. Should be planted in every orchard. The most profitable early apple for commercial purposes.

Early Harvest. Size medium, roundish, usually more or less oblate, smooth, bright straw color when ripe; flesh nearly white, flavor rather acid, fine. Season July. Productive. Needs rich cultivation to be fine. Good throughout the Northern states and Southwest.

Estelle (Northwestern Ironclad). Seedling of Duchess apple. Tree a more rapid grower. Fruit almost identical to Duchess as to season and quality.

Red Astrachan. Origin, Russia. Season, July.
First imported into England with the White Astrachan from Sweden in 1816. Tree upright, spreading, vigorous growth; an early and abundant bearer. Fruit above medium, greenish-yellow, almost covered with mottled and striped crimson; flesh white, crisp, juicy, brisk acid; good.

Red June. Size medium, oblong, very red; flesh white, tender, juicy, sub-acid, with a sprightly agreeable flavor; quite early and continues to ripen for four weeks and will keep long after ripe for a summer apple; profitable for market. The tree is a fine, erect grower, very hardy, bears young and abundantly. A valuable early apple.

Yellow Transparent (White Transparent, Thaler, etc.). Origin, Russia. Season, July. Imported from St. Petersburg by United States Department of Agriculture. One of the most valuable and early apples. Fruit medium, smooth, transparent skin; clear white, becoming pale yellow when fully ripe; flesh white, tender, fine grained, of splendid quality. Tree is moderately vigorous and a good annual bearer.

\section{Crab Apples}

Within the past few years a good many people have given much attention to improving this class of fruit. Their efforts have been attended with marked success. Crab apples succeed equally well in all sections and are valuable for cider, preserving and jellies, and some of the improved sorts are excellent for eating. Every orchard should contain a few, as the trees are handsome, annual bearers and usually fruit the second year.

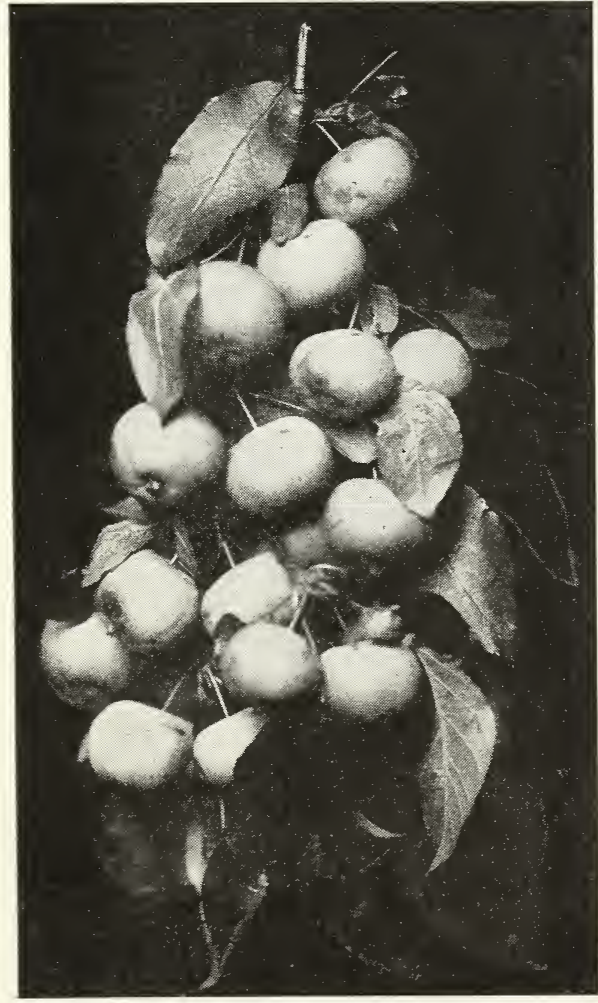

Golden Beauty
Florence, Origin, Minnesota. Season, August. Originated with Peter M. Gideon, who also produced the Wealthy apple. A hardy, spreading tree; bears young and inclined to overbear. Fruit medium; color carmine when well colored; flesh yellowish, medium fine, acid; excellent for cooking. A fine jelly crab, and valuable for early market, as well as home use.

Golden Beauty. Medium size; flesh white, fine grained, mild, sub-acid; one of the best crabs grown; tree vigorous grower.

Hyslop. Origin, America. Season, September to October. Tree vigorous where hardy. Blights in some localities. Fruit medium; yellow grounded with heavy shadings of deep crimson and splashes of maroon with heavy blue bloom; flesh fine, firm, yellow, astringent; bears abundantly in clusters, which make tree exceedingly ornamental. Its high color always commands a fancy market price for it. One of the most desirable crabs for culinary purposes.

Martha. Origin, Minnesota. Season, August and September. Tree a vigorous grower and very free from blight. Fruit large, vellow with heary blush of light red; flesh fine grained, firm; flavor sub-acid, very juicy and exceptionally fine for cooking. Not productive.

Transcendant. Origin, Russia. Season, September. Fruit medium to large, color brownish-rellow with blush of carmine; flesh firm and crisp, yellowish, fine grained, very juicy, acid. Tree is a vigorous grower. Hardy. Subject to blight and should not be planted near other orchard trees.

Whitney (Hybrid) (Whitner No. 20). Origin, Illinois. Season, August. Fruit large to very large for a hybrid; yellow, striped with red and mostly covered with red on sunny side; flesh yellow, very juicy and fine grained; flavor rich and almost sweet. Its crab parentage is shown in the health and vigor of the tree. The fruit equals many apples in size and quality. 


\section{Pears}

The cultivation of this fruit is rapidly extending as its value is appreciated and the demand is increasing every year, making it one of the most profitable to plant. The range of varieties is such that, like apples, they can be had in good eating condition from August until early spring. The melting, juicy texture, the refined flavor and the delicate aroma of the pear give it rank above all other fruits, excepting the grape. One of the most important points about the management of pears is the gathering at the proper time. Summer pears should be gathered at least ten days before they are ripe, and autumn pears at least two weeks. Winter varieties may hang until the leaves begin to fall, then place in a cool, dry cellar.

When the pear trees are heavily laden the fruit should be thinned when about one-third grown, else it will be poor and the tree injured.

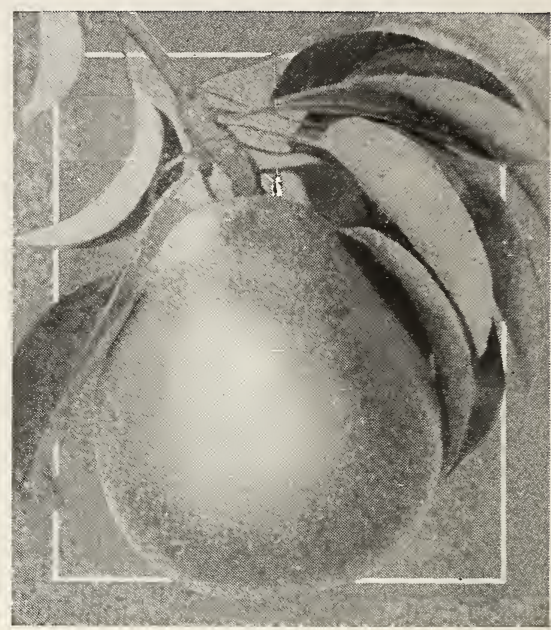

Bartlett

\section{SUMIMER PEARS}

Bartlett. Large size, with a beautiful blush next the sun, buttery, very juicy, and highly flavored; tree a strong grower, bears early and abundantly. A very popular pear. Ripens in August and September.

Clapp's Favorite. A large, fine pear, resembling the Bartlett, but without its musky flavor; pale lemon-yellow with brown dots, and fine texture, melting, buttery, juicy with a delicate flavor; tree hardy and productive. August and September.

Early Harvest. Large, golden-yellow, with bright red cheek, quality not the best, but grown extensively for market on account of its size, beauty and hardiness; ripens ahead of Bartlett.

Wilder. Medium to small, greenish-yellow with a brownish-red cheek; melting, sweet and very pleasant; tree a vigorous grower and good bearer.

\section{AUTUMN PEARS}

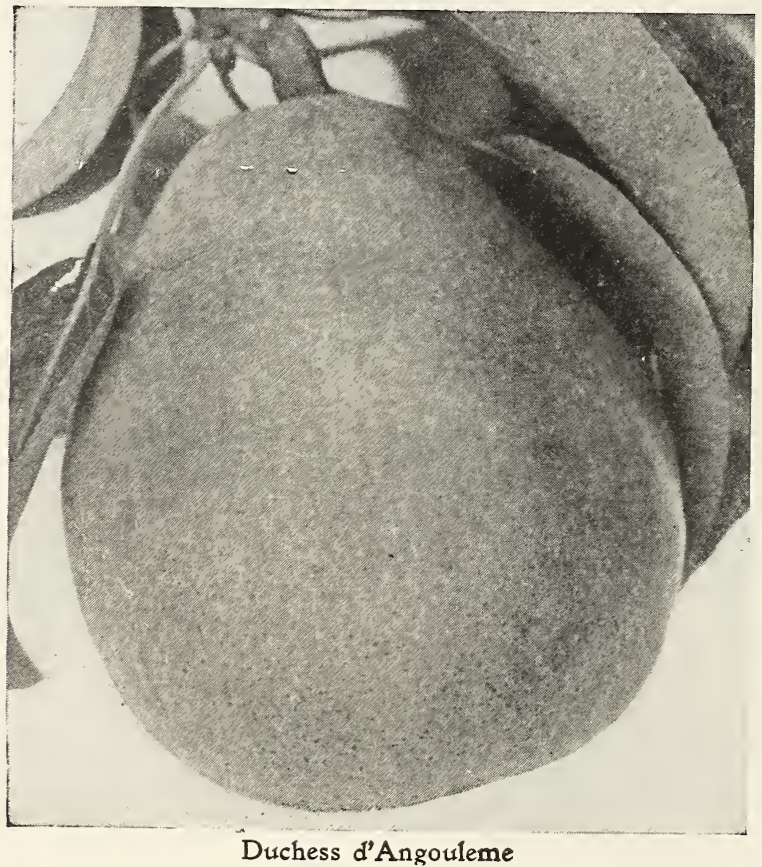

Duchess d'Angouleme. Very large, greenish - yellow, sometimes russeted; makes a beautiful tree and heavy bearer; buttery, melting and sweet. October and November.

Flemish Beauty. Large, juicy, melting and rich; strong grower and good bearer, very hardy. September and $\mathrm{Oc}-$ tober.

Garber. Large, bright yellow, with red, juicy and good; a splendid canning pear; tree vigorous and hardy, not subject to blight; ripens just after Bartlett.

Kieffer. This is the most popular pear grown; fruit of fine size, rich color and good quality; tree very vigorous and seldom blights; should be picked at maturity and ripened indoors. October and November.

Seckel. Small, rich, yellowish-brown; one of the best and highest flavored pears known; very productive. September and October.

Vermont Beauty. Of medium size, roundish, yellow, heavily shaded with carmine; flesh exceedingly fine, sweet and juicy. The tree makes a strong, healthy growth and bears good crops. October. 


\section{Cherries}

There are few more desirable fruits than the Cherry. They are being planted more and more each year and there is always a brisk demand on the market for good fruit. Aside from their fruit value, they make very ornamental trees for the lawn, especially the Heart and Biggereau varieties, which are strong, vigorous growers, with large glossy leaves, and open, spreading heads. Cherries thrive in most any dry or well-drained soil; the fruit is delicious whether eaten out of hand or preserved. No home garden is complete without a few cherry trees.

Baldwin. One of the best of the Morello type; very large, round, color dark yet almost transparent, stem quite large, medium in length; fruits usually in pairs; flesh sub-acid and very good; it fruits early, is hardy; very productive.

Bing. A new black cherry; originated in Oregon; size large, color blackish purple; flesh very solid and of the highest flavor; tree vigorous, upright, hardy and productive; a fine shipping and market cherry.

Black Tartarian. Very large, bright purplish-black; half tender, juicy, very rich and flavor excellent; tree a vigorous grower and productive. June.

Dyehouse. Partakes of both the Duke and Morello in wood and fruit; a very early and sure bearer; ripens a week earlier than Early Richmond.

Early Richmond. Medium size, dark red, melting and juicy, acid flavor; one of the most valuable and popular of the acid cherries and is unsurpassed for cooking; tree slender grower, exceedingly productive and very hardy; will stand the most severe weather.

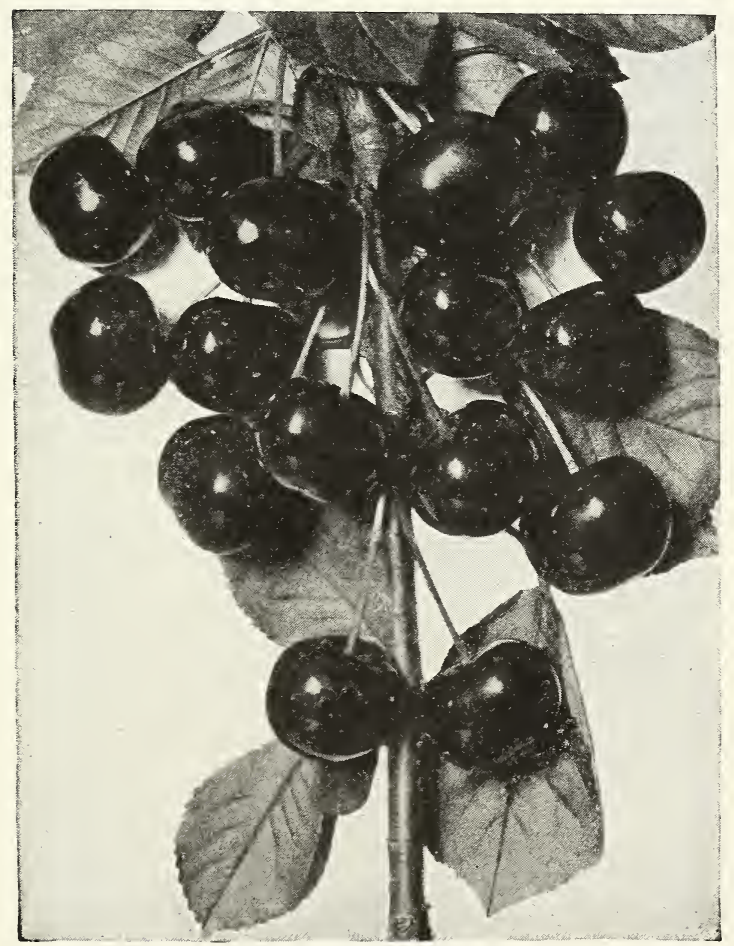

Large Montmorency

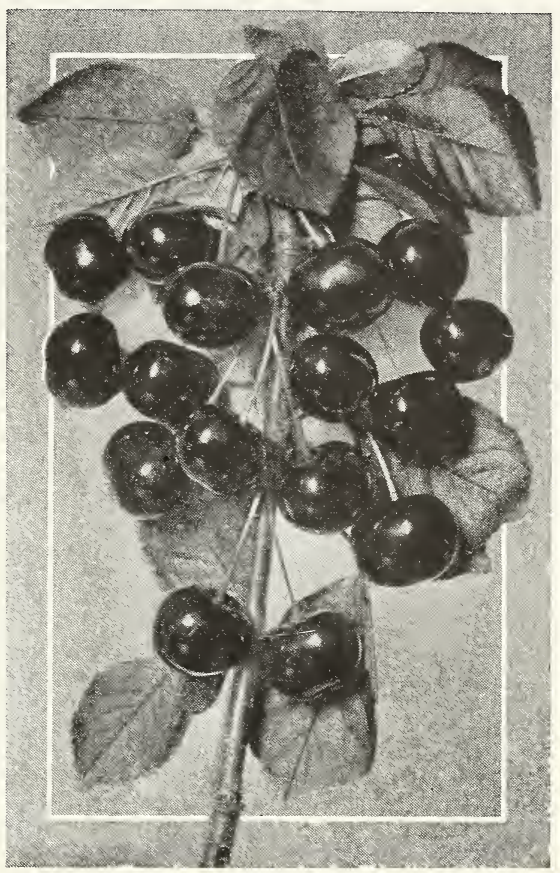

Early Richmond

English Morello. Medium to large, roundish; dark red, nearly black when ripe; flesh purplish-red, meaty, juicy, slightly astringent and good; very productlve. August.

Governor Wood. Large, rich, light yellow with red cheek, juicy and sweet. Late June.

Large Montmorency. Large, roundish, red; flesh tender, mildly acid and good quality; larger than Early Richmond and about ten days later; one of the most popular sorts; late June.

Late Duke. Large, heart-shaped, dark handsome red when fully ripe; flesh light colored, sub-acid; flavor good; one of the latest.

Ostheim. Large, roundish, one side compressed, dark red and much darker when fully ripe; flesh liver colored, tender, juicy, sub-acid and very good; early and ripens over a long period.

Windsor. Of Canadian origin and noted for the hardiness of fruit and bud; large, dull red, almost liver colored; substantial and meaty; without doubt the hardiest of the sweets. Popular in the East.

Wragg. Large, roundish, heart-shaped; dark crimson and when fully ripe, black or nearly so; flesh and juice light crimson, firm and good; very productive. One of the hardiest and is usually a sure cropper.

Why not plant a Cherry Orchard? The Fruit always demands a good price. 


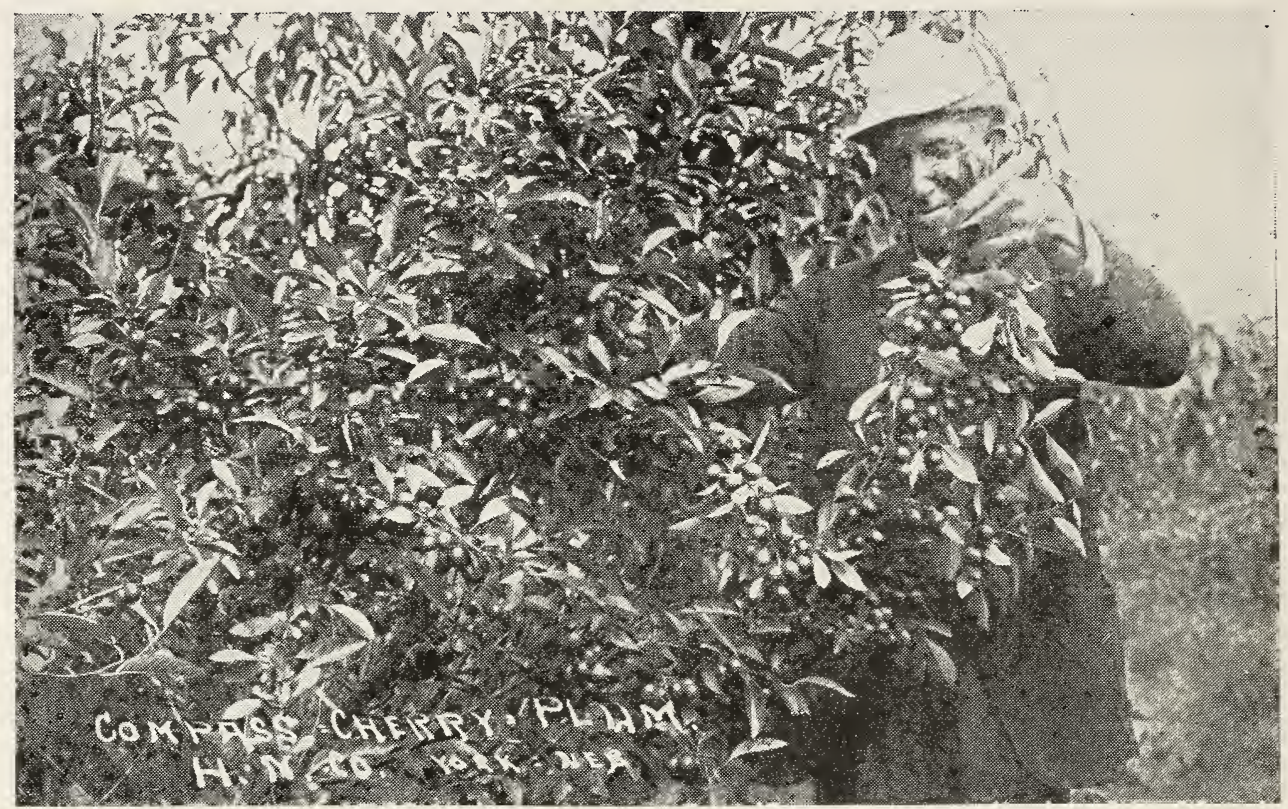

\section{Compass Cherry-Plum}

Compass Cherry-Plum. Originated at Springfield, Minnesota, by M. H. Knudson, through scientific hybridization by applying pollen of the English Morello Cherry and Miner Plum to the blossom of the Sand Cherry (Prunus Besseyii). It is absolutely hardy, wonderfully prolific, frequently producing fruit on young trees in nursery row. In shape, size and coloring of the fruit the characteristics of the Plum and Cherry are about equally divided. Color bright red, deepening as it becomes well ripened, until it reaches a rich, dark wine color. Valuable for canning and preserving.

The Compass fills a unique place in the North, where it stands today as the principal hardy fruit approaching the Cherry, and is especially recommended for planting where cherries of the Morello type are not successful.

\section{DWARF ROCKY MOUNTAIN CHERRY}

(Prunus Pumila Besseyii). A very hardy native dwarf cherry, growing in shrub form. Bears large crops of medium sized black cherries, which when fully ripe are of fair quality; used for cooking and preserving with good results. 3 to 4 feet only.

\section{Plums}

The plum, like the pear and other finer fruits, succeeds best in heary soil with some clay, and being almost entirely free from disease, they can be grown very profitably. Of late years the demand has been growing very rapidly. The finer kinds are excellent dessert fruits of rich and luscious flavor; for cooking and canning they are unsurpassed. For home consumption they should be allowed to remain on the trees until fully ripe, but for shipping they should be gathered a few days earlier. Some of the varieties are inclined to overbear and should be thinned in order to produce perfect fruit. Most all the varieties, especially the native sorts, are extremely hardy and will withstand the most serere weather.

\section{EUROPEAN PLUMS}

Bradshaw. Very large, dark violet red; flesh yellowish-green, juicy and pleasant; tree vigorous, erect and productive. August.

German Prune. Medium, oval, purplish-blue; rich, juicy and of high flavor; tree vigorous and very productive.

Gold. This was Luther Burbank's first great origination and was his first choice from among twenty million native, hybrid and cross-bred seedlings grown by him. Small, slender limbs, a rather dwarfish-growing, but strong tree. One of the hardiest. Color, transparent light golden yellow, nearly overspread with a beautiful blush. One of the handsomest plums in existence.

Imperial Gage. Large, oval, yellowish-green with marbled green stripes, heavy white bloom, flesh greenish, juicy, melting, rich and best quality; tree upright and vigorous. September.

Lombard. Medium, roundish-oval, riolet-red, juicy and pleasant; adheres to stone; a valuable market sort, hardy and adapted to light soils; nearly always produces a crop. 
Moore's Arctic. Grows in large clusters, large, dark purple; flesh very fine; splendid for preserving and dessert; tree vigorous and prolific; fruit is a long keeper.

Shipper's Pride. Large, nearly round, dark purple, juicy and sweet; a splendid shipper and good market variety; tree moderate grower, but productive.

\section{JAPANESE PLUMS}

Abundance. One of the best Japan plums. Tree is a very rapid grower, healthy and comes into bearing quite young and yields abundantly; medium size, rich, bright cherry-red with distinct bloom and highly perfumed; flesh light yellow, juicy and tender and excellent quality; tree vigorous and hardy.

Burbank. Medium to large, orange-yellow, dotted and marbled with red; flesh meaty, yellow, sweet and good; valuable for canning and a good market plum; mid-June. Hardiest and most prolific of the Japan varieties.

Wickson. Large, heart-shaped, deep maroon red; flesh very firm, yellow, sub-acid, rich and good; a good shipping plum; tree upright, but in some localities a shy bearer.

\section{NATIVE PLUMS}

Admiral Schley. A new variety sent out by Mr. Terry, of Iowa, a plum expert. The tree resembles somewhat the Stoddard and the Forest Garden. The fruit is much larger though, and of fully better quality. For two seasons it has taken the premiums over all plums at the Iowa State Fair. One of the very best and most profitable of the native type of plums. Although it is a recent introduction we offer them at the same price as other plums.

Cheney. Large, roundish, oblong, deep mottled red on greenish-yellow ground; blue bloom; flesh yellow, firm and of good quality. Middle of August.

De Soto. Large, oval, orange overlaid with crimson, numerous dots and thin blue bloom; flesh firm, juicy and high-flavored; one of the best natives in quality.

Forest Garden. Large, nearly round, deep red when fully ripe with numerous yellow specks; flesh firm, sub-acid, good quality; season late.

Hawkeye. Very large, dark red, handsome, rich and good; tree a moderate grower, with broad shining leaves; hardy and profitable. August.

Klondike. Medium to small, roundish-oval, bright yellow, shaded with red and many small dots; flesh juicy, pleasant, sub-acid; quality good; early August.

The Omaha. A large, nearly round plum, light brilliant red; flesh firm, rich yellow, juicy and sweet. Tree is a strong, vigorous grower, hardy and productive. The Omaha originated with the late Theo. Williams, Benson, Nebraska, who has done so much to develop a race of hardy plums.

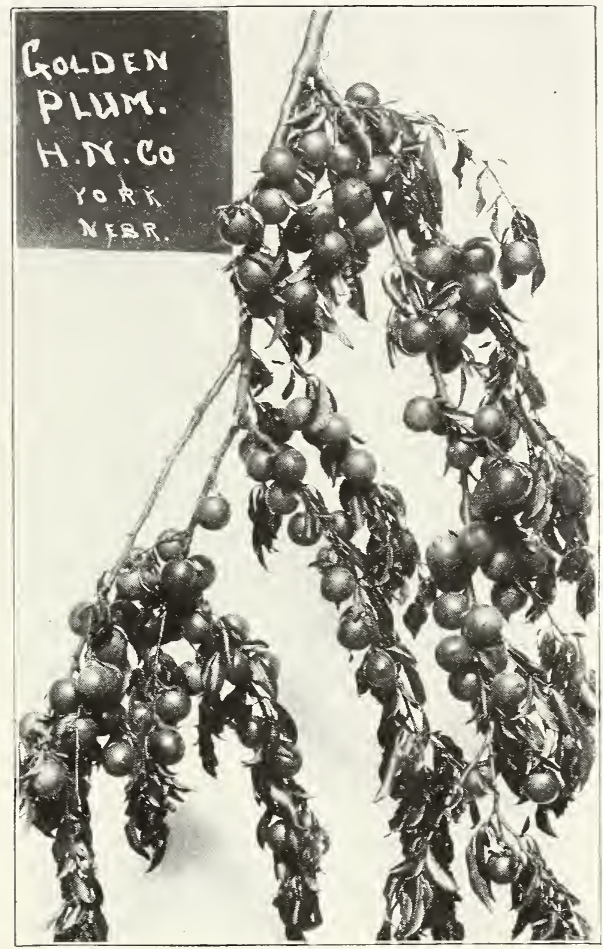

Golden Plum

Stoddard. Largest American plum known. It is a pure American, but shows strong markings of the Japan type in leaf and fruit; the tree is a good, stout grower, beautiful enough for the lawn. An early bearer and perfectly hardy. August.

Surprise, Large, roundish-oval, dark red with many small yellow dots; flesh pale yellow, firm and of good quality.

Weaver. Large, oblong, flattened at cnds, dark mottled red with purplish bloom; flesh firm, meaty and very good; a constant and regular bearer and very hardy.

Wild Goose. Medium to large; roundish-oblong, skin light red and shining, making an attractive market plum; flesh yellow, pulpy and sweet; very popular, but a poor fertilizer. Should be planted with other trees of abundant pollen.

Wolf. Medium to large, yellow mottled with red; flesh yellow, firm and good quality; tree vigorous and a prolific bearer.

Wyant. Medium to large, oblong, purple-red on yellow ground; flesh firm and good quality; one of the most popular of the American sorts.

\section{Apricots}

A beautiful and delicious fruit; a close relative of the plum and peach, combining the qualities of both. The fruit ripens after the early cherries and just before plums and peaches. Tree is as hardy as the peach and requires about the same cultivation. It ships well and commands a good price in the markets, and for drying and canning it has no superior. Russian varieties are the earliest and most hardy.

Alexander (Russian). Medium to small, light orange, yellow flecked with red; flesh tender, juicy, sweet and good quality; hardy; productive. July.
Budd (Russian). Medium to large; light orange with blush on sunny side; flesh sweet, juicy, with flavor of the peach; hardy and productive. August. 


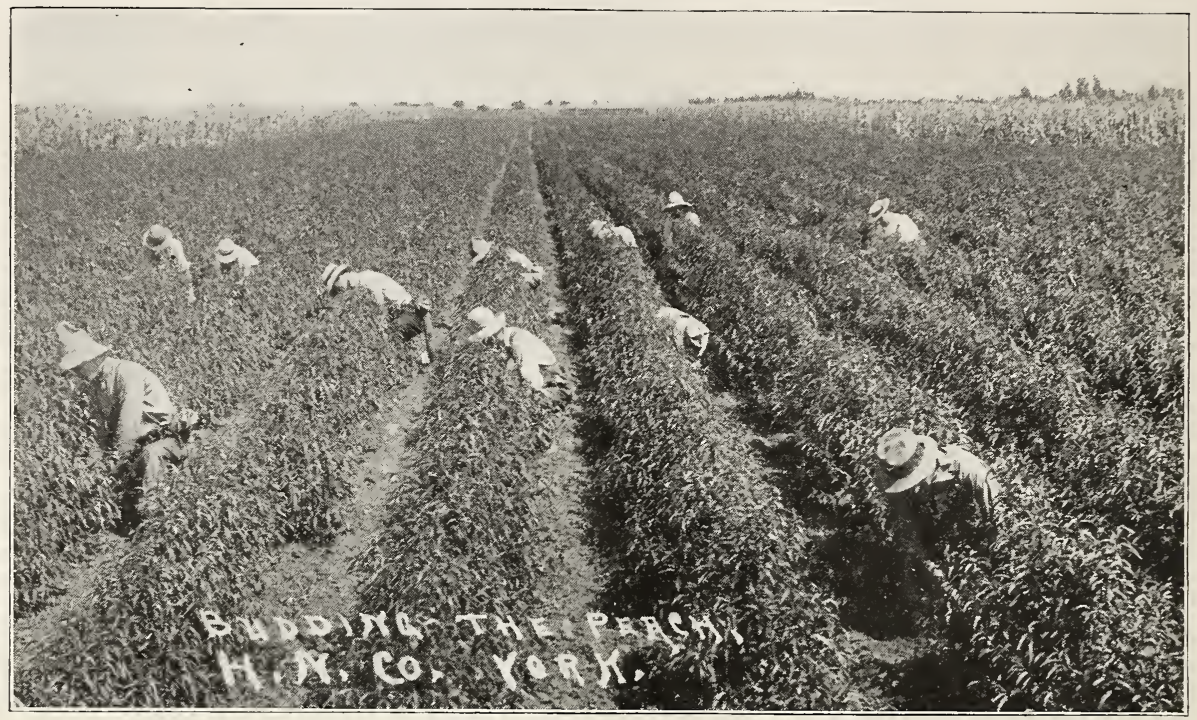

\section{Peaches}

To secure healthy, vigorous and fruitful trees, the ground must be well drained and kept clean and mellow. Peach trees are easily cultivated and their freedom from disease, the short time it takes to come into bearing and the immense demand for the fruit, makes them extremely profitable. Peaches are borne on wood of the previous season's growth, and this makes it absolutely essential to prune the trees yearly, remove dead branches and let in light and air. Keep the trees in good shape and you will have splendid returns.

Alexander (Cling). Medium size; greenish-white, nearly covered with rich red; flesh sweet, juicy; vigorous, productive. Good market peach.

Bokara No. 3 (Free). Large, yellow with red cheeks; flesh yellow, firm and melting; an excellent keeper.

Champion (Free). Large, round, quite regular; yellowish-white mottled with red on sunny side; flesh white with red at the pit; one of the best in quality.

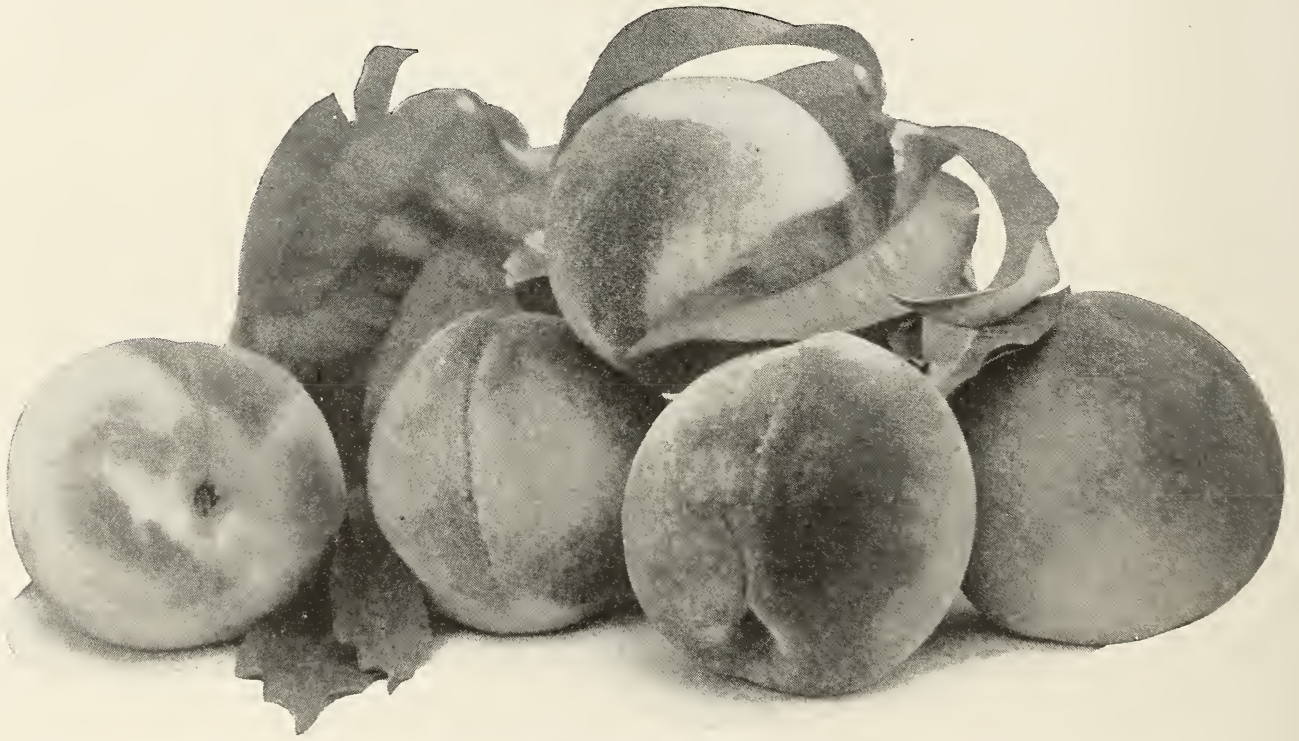

Champion Peaches 
Crosby (Free). Medium to large; orange-yellow splashed with red; flesh yellow, red at pit, juicy and rich; tree hardy and prolific; fruit should be thinned in order to make good sized peaches; a popular market sort. Middle of September.

Early Rivers (Cling). Large, creamy-white with delicate pink cheek; flesh melting with rich, racy flavor; one of the best for home or market.

Elberta (Free). The great market peach of the Southwest; perfectly hardy in the North and is beleived by many growers to be the best all around peach; color lemon-yellow with blush on sunny side; flesh pale yellow, tender and juicy; tree vigorous; a good shipping peach.

Hale's Early (Semi-Cling). Medium, greenish- white with red cheek; flesh white, melting, juicy; vigorous, healthy; abundant bearer. July-August.

Hill's Chili (Free). One of the best; medium to large oval, yellow with red; flesh rather dry, but good. Valuable sort for drying. September.

Triumph (Free). Medium to large, round, somewhat flattened, greenish-yellow, broken stripes of purplish-red and pink dots; flesh yellow with red stains, juicy and very good; one of the early sorts.

Wright. An Iowa seedling; tree dwarfish, spreading, willowy habit; fruit slightly below medium size, light yellow splashed with red on sunny side; flesh white, best quality, small pit. Profuse bearer; has proven to be much hardier than any of the old varieties; worthy of a trial. Season, September.

\section{Grapes}

Everyone should have a few grape vines in the home garden. They require very little cultivation and the returns are so abundant. If proper selection of varieties is made, one may have grapes on the table for several months in the year. They can be trained over fences, trellises, or doorways and thus be ornamental as well as useful. To grow for market, they can be planted on hillsides that are unsuitable for other crops. They should in all cases have a free exposure to the sun and air.

Agawam (Red). Bunch large, compact, shouidered, berry large, dark red or nearly black; flesh tender, juicy, vinous and good quality; later than Concord.

Brighton (Red). Bunch medium to large, quite compact, flesh rich, sweet and best quality, color dark crimson or brownish red; vine vigorous and hardy.

Campbell's Early (Black). A strong, vigorous and hardy sort; ripens early and bears abundantly; berry large, black with blue bloom; tender, sweet and rich; good market berry; it is a good shipper and long keeper.

Catawba (Red). Bunches medium, shouldered; berries large, deep coppery red, becoming purple when ripe; flesh somewhat pulpy, juicy, sweet aromatic and rich. One of the latest. Does not ripen well in the North.

Champion (Black). Bunch medium, compact; berries medium, quality fair; on account of the vigorous vine, showy fruit and heavy bearing, it is extensively grown for market.

Clinton (Black). Bunches medium, compact; berries round, small, with thin blue bloom, pulpy and juicy; hardy and late; good keeper and valuable as a wine grape.

Concord (Black). Too well known to need much description; is considered by many to be the best all around grape grown; is extremely hardy, vigorous and productive; bunches large, compact; berries large, juicy, buttery and sweet; will succeed well almost anywhere.

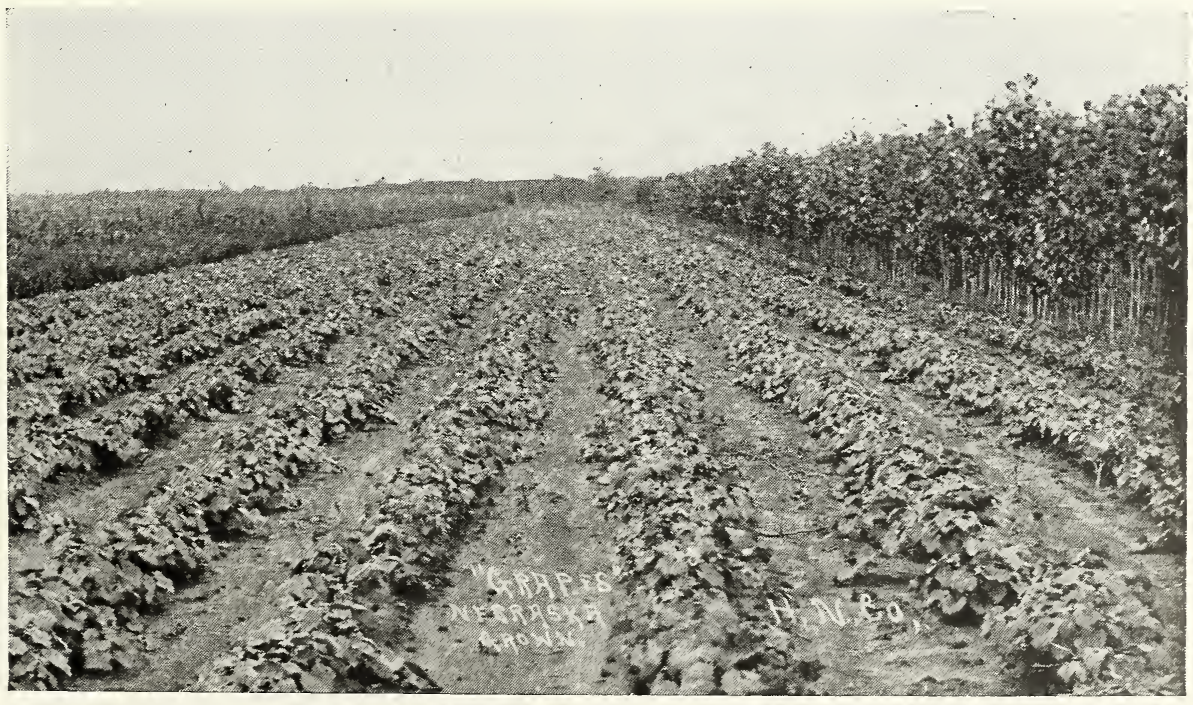


Delaware (Red). One of the best red grapes; bunch small and compact, berry small, round, beautiful light red; flesh rich, vinous, sweet and delicious; best quality. Good market grape.

Elvira (White). Bunch medium, shouldered and very compact; berry medium, pale green with yellow shade, sweet, tender and free from foxiness; grown in the West as a wine grape.

Empire State (White). Bunch long and large; berry medium, light green or white, yellow tinged, covered with a white bloom; tender, sweet and sprightly; good keeper.

Green Mountain (White). The earliest white grape; bunch medium to large, shouldered; berries medium, greenish-white, tender, sweet and excellent quality, combines hardiness, fruitfulness, vigor and health.

Janesville (Black). Its hardiness, vigor and productiveness has made it one of the best black sorts. It is especially adapted to the North; bunch medium to large, short and shouldered; berries round, with slight blue bloom, tender and vinous; quality fair.

Lindley (Red). Bunch large, long and compact; berry medium, pale red with violet bloom, sweet, juicy, high-flavored and good, hardy and vigorous.

Martha (White). One of the most reliable white grapes; bunch medium, compact and shouldered; berry medium, greenish-yellow with bloom, sweet, juicy and tender; ripens a little earlier than Concord.

Moore's Diamond (White). A vigorous grower entirely free from mildew and a prolific bearer; bunches large and compact, slightly shouldered; color delicate greenish-

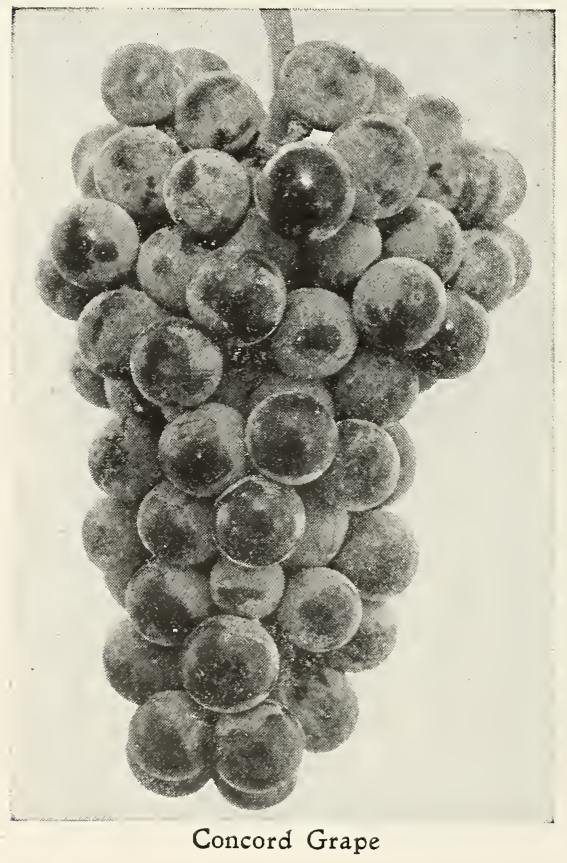

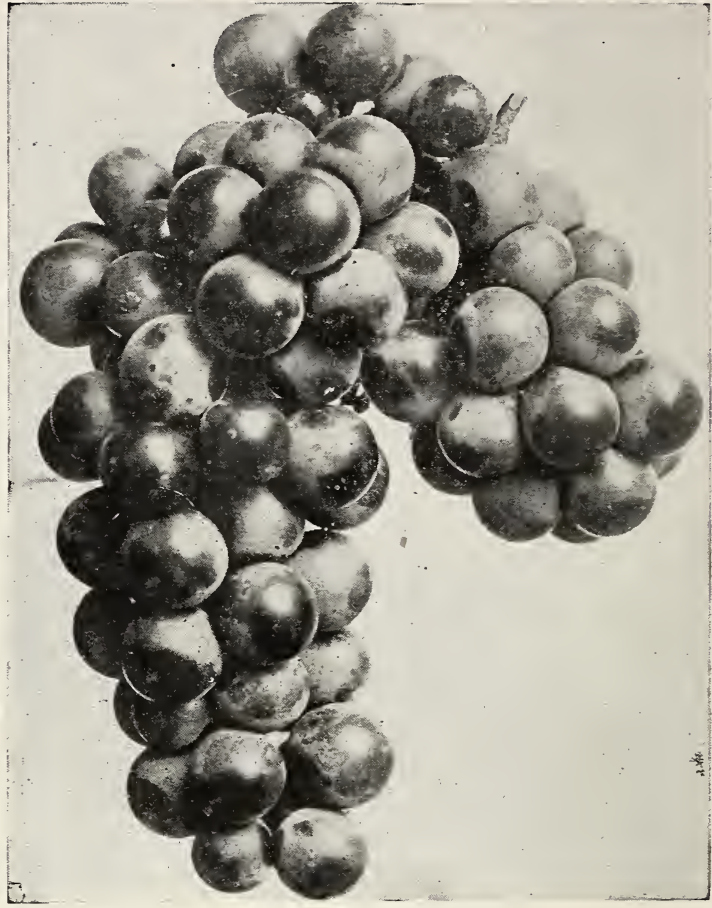

Moore's Early Grape

white with yellow tinge when ripe; berries tender, juicy, nearly transparent, sweet, rich; ripens about two weeks before Concord.

Moore's Early (Black). Bunch large, berry round with heary blue bloom, quality said to be better than Concord; hardy, prolific; a good market grape; ripens about two weeks before Concord.

Niagara (White). One of the leading white sorts; bunch large, shouldered, compact; berry large, vellowishwhite, juicy; vinous and sprightly, quality good; skin tough; good for market.

Pocklington (White). The great vigor and hardiness of the vine with the beauty and size of the clusters, place this in the front rank of white grapes; berry a light lemon-yellow, tender, sweet and fine aromatic flavor; very prolific.

Salem (Red). Bunch medium, shouldered and compact: vine strong and vigorous; berry large, coppery red, thin skin, sweet and sprightly; a good market berry. Ripens in September.

Vergennes (Red). Bunch large and compact; berry large, amber red with gravish bloom, tender, vinous, rich, good. Splendid market grape.

Wilder (Black). Bunch large, compact and generally shouldered; large, black with thin blue bloom, tender, sweet, slightly aromatic, good.

Worden (Black). A seedling of the Concord; bunch large and compact, berry round, black with blue bloom, pulpy, juicy and very pleasant; ripens several days earlier than Concord.

Woodruff (Red). Bunch very large, shouldered and roundish; berries are round, red with some bloom, juicr, sub-acid and good.

Wyoming (Red). Bunch small and compact; berry medium, red, brighter than Delaware; tender, juicy, sweet and very good; a hards, vigorous and prolific grape. It is one of the best early red grapes. 


\section{Strawberries}

Strawberries can be successfully grown in any good garden soil. It is easily placed in the front rank among smali fruits and owing to the wide range in which it can be grown, there is always a good market for several weeks of the year. No fruit lends itself so readily to the varied uses of the table or for canning purposes or preserving. The varieties that we list are all standard and the best. "S" or staminate varieties fertilize themselves. "P" or pistillate varieties require to be planted with staminate in order to produce good crops.

Bederwood (S). A very desirable early berry; medium to large, very firm, sweet and good. A vigorous grower and enormous yielder.

Brandywine (S). A good market berry; medium to large; dark scarlet, firm and somewhat acid; a good bearer and does well in clay soil. Mid-season.

Bubach (P). Large, conical and irregular; dark red or crimson, sweet and good quality; plant vigorous, healthy and a good bearer; popular as a home garden berry and for nearby market. Mid-season.

Crescent (P). Medium size, conical, light red or scarlet; seeds prominent; an old, well-known, popular variety; succeeds in all soils.

Gandy (S). Large, regular and conical; bright glossy crimson, firm, fine flavor, vigorous and prolific; a fine late sort and a good shipper.
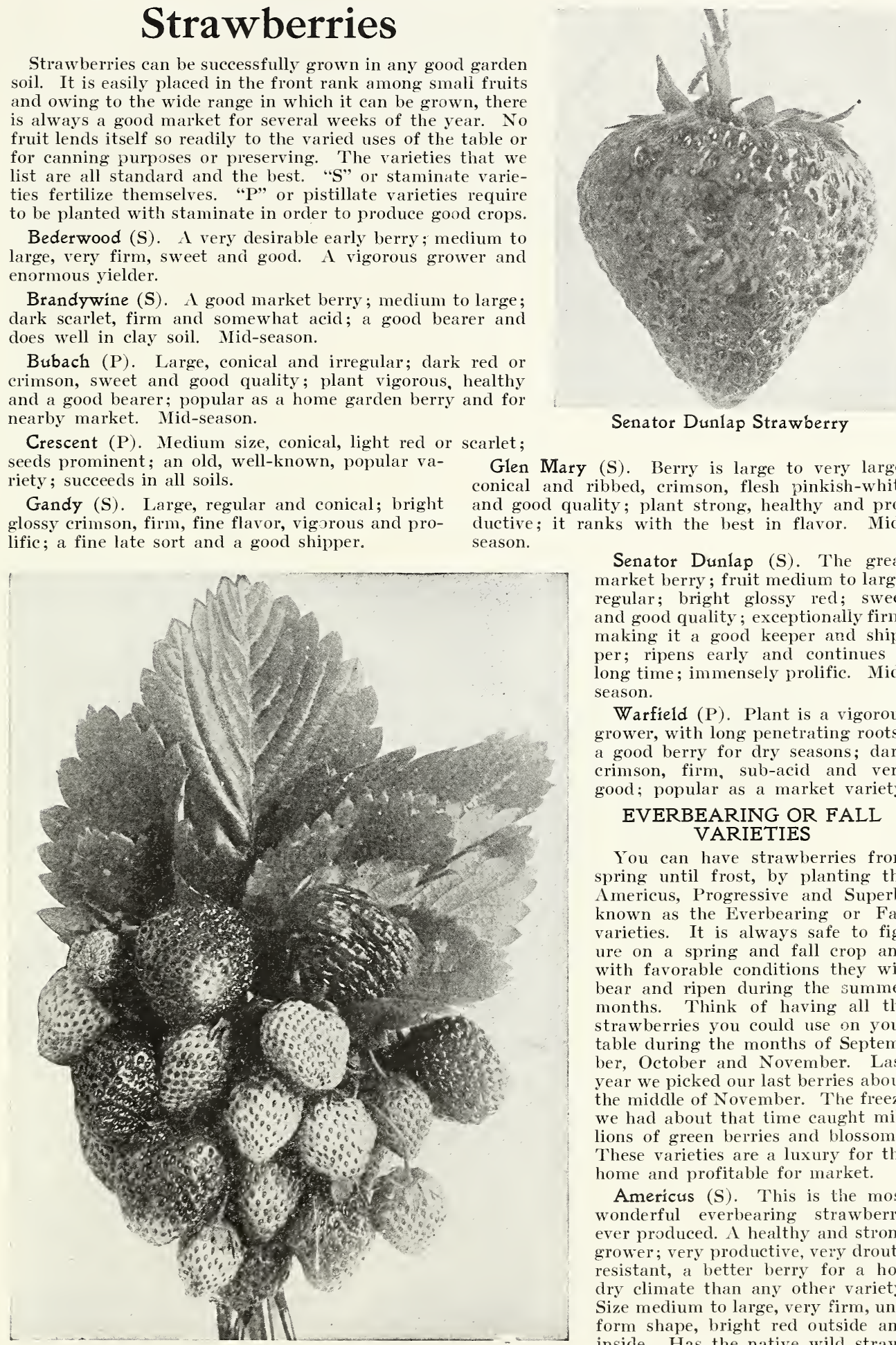

Progressive Everbearing Strawberry

Glen Mary (S). Berry is large to very large, conical and ribbed, crimson, flesh pinkish-white and good quality; plant strong, healthy and productive; it ranks with the best in flavor. Midseason.

Senator Dunlap (S). The great market berry ; fruit medium to large, regular; bright glossy red; sweet and good quality; exceptionalily firm, making it a good keeper and shipper; ripens early and continues a long time; immensely prolific. Midseason.

Warfield (P). Plant is a vigorous grower, with long penetrating roots; a good berry for dry seasons; dark crimson, firm, sub-acid and very good; popular as a market variety.

\section{EVERBEARING OR FALL}

\section{VARIETIES}

You can have strawberries from spring until frost, by planting the Americus, Progressive and Superb, known as the Everbearing or Fall varieties. It is always safe to figure on a spring and fall crop and with favorable conditions they will bear and ripen during the summer months. Think of having all the strawberries you could use on your table during the months of September, October and November. Last year we picked our last berries about the middle of November. The freeze we had about that time caught millions of green berries and blossoms. These varieties are a luxury for the home and profitable for market.

Americus (S). This is the most wonderful everbearing strawberry ever produced. A healthy and strong grower; very productive, very drouth resistant, a better berry for a hot, dry climate than any othei variety. Size medium to large, very firm, uniform shape, bright red outside anc inside. Has the native wild strawberry flavor. Succeeds well anywhere. 
Superb (S). Cooper's introduction. Berry glossy, rery attractive, and of the finest flavor. Size of berry very large and firm. Brings every blossom to maturity, which is a strong point in a fall-bearing strawberry. The plants are strong and stand the winter well, after producing a heary fall crop. Superb will please you and will bring you nice fresh strawberries in the late summer and fall.
Progressive (S). This new fall-bearing variety seems to be a rery good one. The new runner plants produce a nice lot of berries in good quality. The berries are not as large as Superb and not so good quality, but they yield well and, we think, will be one of the best known varieties of fallbearers in a few years. The fruit of Progressice is of good size, smooth, of good color and appearance. Very strong plants.

\section{Dewberries}

The Dewberry is a dwarf and trailing form of the Blackberry. The fruit is highly prized as a market fruit owing to its large size and fine quality. Set the plants two feet apart in the row and cover in winter with coarse litter. Should be mulched in the spring to keep them off the ground.

Austin. Glossy shining black color; flavor is most excellent and when fully ripe will fairly melt in your mouth; has the hardy characteristics of the Dewberry family; very productive.

Lucretia. Perfectly hardy and remarkably productive; said to be the best of this class of fruit; ripens early; is often one and one-half inches long by one inch in diameter; sweet, luscious and melting; this rariety is recommended most highly.

Premo. Very large, jet black and good; crop ripens fast and erenly from seren to ten days earlier than Lucretia; is better and firmer in quality; an extra early sort.

\section{Blackberries}

Blackberries are among the best known and most valued of our berries. No fruit of any kind is more wholesome. A liberal use of berries and other good fruit will save doctors' bills. Blackberries should be planted in rows six or seren feet apart, three to four feet in the row. Keep the ground light, rich and clean, and pinch the canes back when they have reached four feet in height. The demand for blackberries is alwars good.

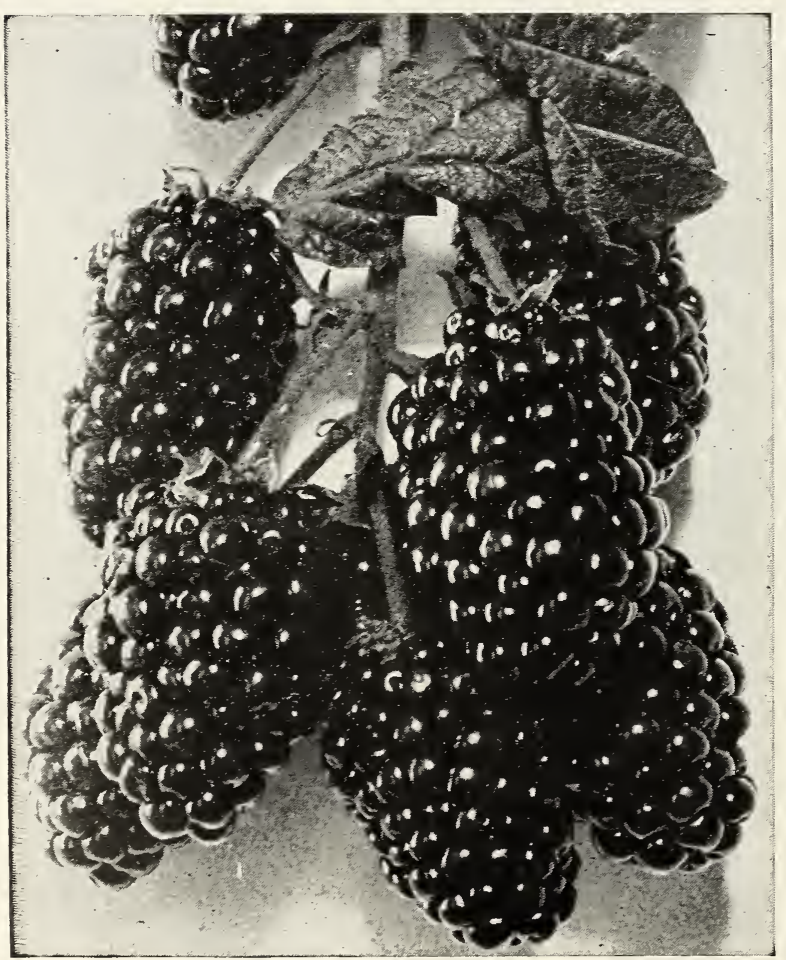

Snyder Blackberry
Early Harvest. One of the earliest, berry medium sized, good quality and rery prolific; firm and attractive in appearance. A good market sort.

Eldorado. Yine is rigorous and hardy; berries are very large, black, borne in clusters; ripens well together; sweet, melting and pleasing to the taste.

Erie. One of the very best large new blackberries; absolutely hardy, very black, firm and solid; ripens early.

Mersereats. Large, oral, sparkling black, sweet, rich and melting, hardy and productive.

Rathbun. A strong, erect grower and hardy; fruit is sweet, luscious, without a hard core; high flavor; jet black, small seeds; firm enough to ship and handle well. One of the largest sized berries.

Snyder. The hardiest blackberry known; fruit medium sized and of a good quality; a standard market variety.

Stone's Hardy. A rigorous grower; berry glossy black and of a good flaror. A little later than the Snyder; very hardy.

Taylor. Large, oblong. soft; juicy, sub-acid and rich; later than Snyder.

Wílson's Early. Very large, black, sweet, rich and good quality; ripens early and is productive. 

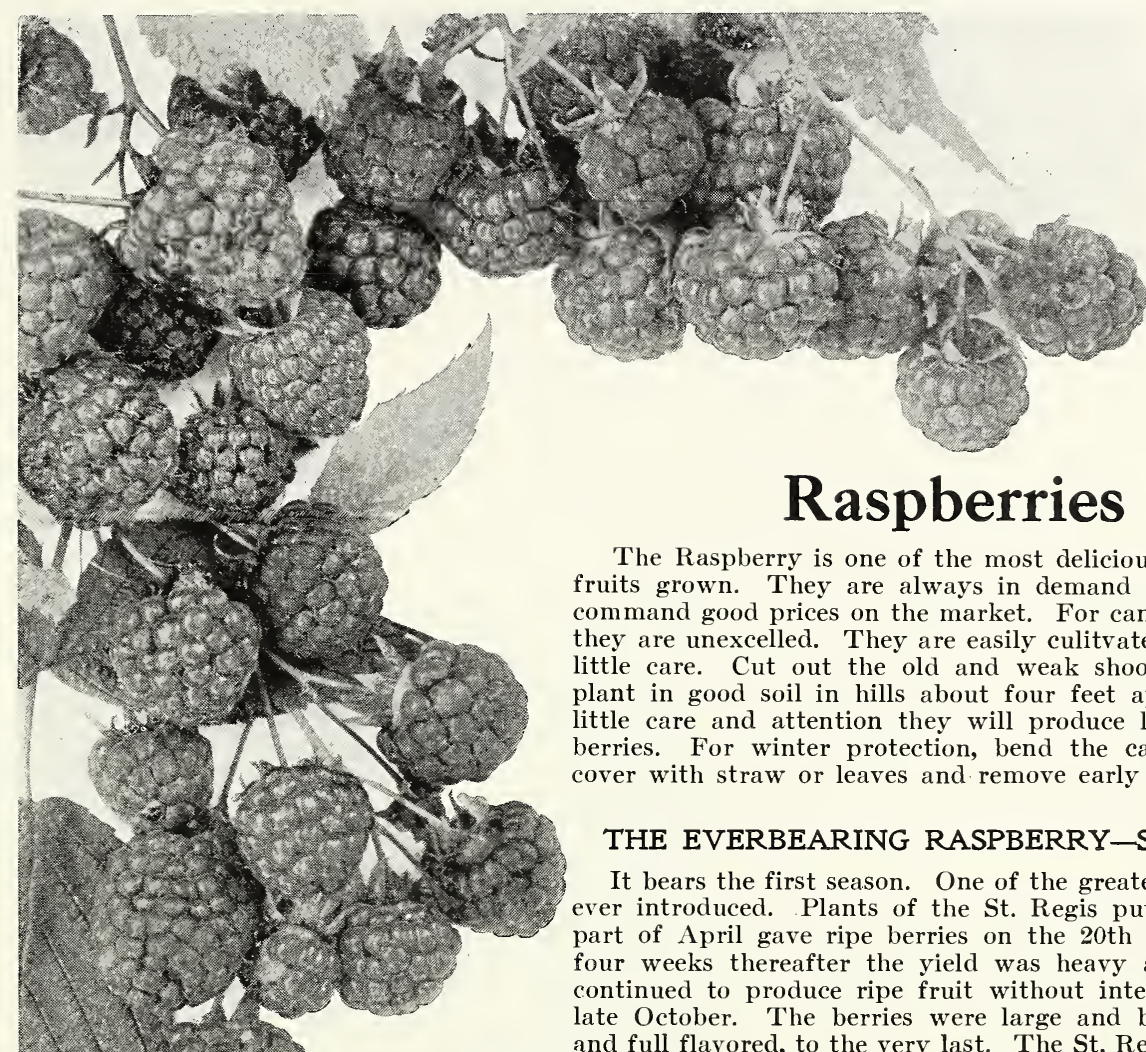

The Raspberry is one of the most delicious and popular fruits grown. They are always in demand in season and command good prices on the market. For canning purposes they are unexcelled. They are easily culitvated and require little care. Cut out the old and weak shoots each year; plant in good soil in hills about four feet apart. With a little care and attention they will produce large crops of berries. For winter protection, bend the canes over and cover with straw or leaves and remove early in the spring.

\section{THE EVERBEARING RASPBERRY-ST. REGIS}

It bears the first season. One of the greatest raspberries ever introduced. Plants of the St. Regis put out in early part of April gave ripe berries on the 20th of June. For four weeks thereafter the yield was heavy and the canes continued to produce ripe fruit without intermission until late October. The berries were large and beautiful, firm and full flavored, to the very last. The St. Regis is the only raspberry, as far as known, that is practically sure to produce a crop of fruit the season planted. Awarded the highest certificate of merit by the American Institute of New York.

Brandywine (Red). Large, bright and very firm; a good market berry and valuable for its shipping qualities.

St. Regis

Raspberry

Cardinal (Red). One of the new sorts; it is extremely hardy and productive; fruit is rich, red and highly flavored. It is the opinion of leading horticulturists that it is the best of the good varieties now being grown.

Columbian (Red). Resembles the Shaffer, but is mucn better; the berry is firmer, dark red and adheres to the bushes much longer; a strong grower, attaining large size. One of the hardiest and most productive and stands at the head for canning, jams, etc.

Cumberland (Black). The largest of all black caps; a healthy, vigorous grower, throwing up stout, stocky, well branched canes that produce immense crops of magnificent berries. Fruit very large, firm, quality about the same as Gregg; keeps and ships as well as any of the blacks. The most profitable market variety.

Cuthbert (Red). Large, bright scarlet-crimson, excellent quality, firm, juicy and refreshing, vigorous grower, hardy and productive. Very popular as a home garden and market berry.

Eureka (Black). Berry medium to large, round, firm, juicy and good quality. Has a long season and is valued as a splendid market sort.

Gregg (Black). Of good size, fine quality, productive and hardy, firm, sweet and rich; strong grower and good bearer. Ripens late and evenly. Good market berry.
Kansas (Black). Large, round and firm, moderately juicy, strong grower and very productive. Ripens early. Considered one of the best market berries on account of its handsome appearance.

Loudon (Red). Large, firm and of good quality ; dark crimson; very productive, hardy and vigorous.

Marlboro (Red). The largest early red; bright scarlet, sub-acid, pleasant and good; hardy and productive.

Miller (Red). Bright red color; is a healthy, vigorous grower, canes strong, well adapted to carrying their heavy load of berries; firm and a good shipper; an early ripener.

Minnetonka-Ironclad (Red). Medium size, bright scarlet, sweet, rich and good quality. Considered by some to be equal to Turner and in some places better.

Munger (Black). Resembles the Gregg; excels it in size and flavor and also a better shipper; sweet, juicy and good; large and of fine quality; a strong, vigorous grower and extremely hardy.

Turner (Red). A fine old variety and a general favorite everywhere; owing to its good size, fine 
appearance and great productiveness is a profitable market sort. A strong grower and produces good crops annually.

Plum Farmer (Black). A rigorous, stocky growing black cap, very healthy and attractive in appearance; productive, bearing heary crops of large, fine jet black berries; excellent quality and a good shipper. One of the most raluable market berries, as it commands top prices.
Older (Black). One of the lately introduced rarieties which has been receiring considerable attention in the Northwest. Ripens a trifle in adrance of Gregg. Fruit similar to Gregg in size, but is very distinct from all other black caps in general appearance; jet black, sweet and of excellent quality; hardy; adheres well to the bush.

\section{Currants}

The Currant is one of the most ralued of the small fruits. They mature just before raspberries and can be used either raw or cooked. Being rery hardy, they do not winter-kill and are easy of cultiration, requiring little care. They can be grown in any good garden soil.

Black Champion. Very productive, large bunch and berry, excellent quality and a strong grower.

Black Naples. Yery large, black, rich, tender and excellent for jellies and wine; very productive.

Black Victoria. An English rariety of exceptional merit; said to be the largest black currant in cultivation; good flavor and very productive.

Cherry. Large, deep red; rather acid, short branches, rery productive.

Crandall. A seedling of the Missouri River wild currant, much larger and much more prolific.

Fay's Prolific. A cross between the Cherry and Victoria; one of the most popular of the red currants and immensely prolific.

Lee Prolific. A new English rariety; the fruit is large and of superior quality; vigorous and immensely productive. Is classed with the black rarieties.

Long Bunch Holland. One of the best late rarieties; bush rery rigorous and hardy, clusters long; berry medium to large, bright red and good quality.

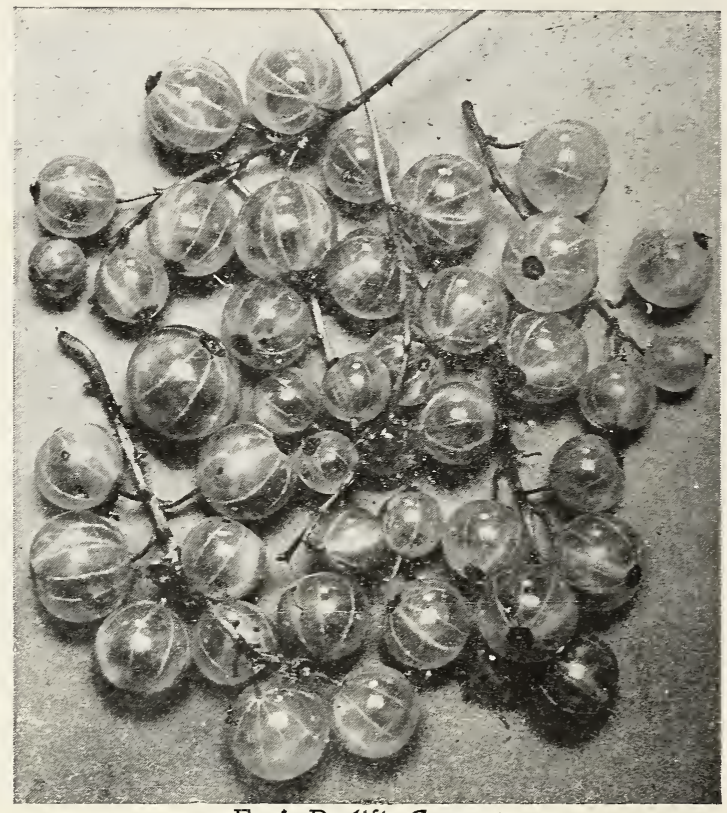

Fay's Prolific Currant

North Star. Said to be the strongest grower among the red rarieties; bunches arerage four inches in length and are freely produced; extra quality and extremely hardy.

Perfection. Berries are a beautiful bright red and larger than Fay's Prolific. In quality it is said to be superior to anything in the market today; rich, mild, sub-acid flavor, with plenty of pulp and few seeds; clusters are long and size of berry is maintained to the end.

Pomona. Fruit of good size and flaror; bright red; has long stems and hangs in fine condition after ripening; is a good shipper; bush bears early and is wonderfully prolific. Good market sort.

Red Cross. A strong growing variety with long clusters; berry medium to large, bright red, mild; good quality and fine flaror.

Red Dutch. An old well-known standard rariety; berries dark red, sub-acid and sprightly flaror; clusters medium to large.

Versailles, A French rariety resembling the Cherry; deep red, bunch and berry large and handsome; very productive.

Victoria, Clusters medium, berries medium to large, bright red, mild sub-acid. One of the most valuable late rarieties.

White Dutch. Clusters two to three inches long; berries medium, translucent, a little darker than White Grape; quality excellent and ripens early; vigorous and productive.

White Grape. Bush rigorous and productive; clusters long; berries large, very attractive, mild flavor and good quality; a good table variety. Distinct from White Dutch.

Wilder. Clusters abore medium length and berries large, bright red, of excellent quality, with mild, sub-acid flavor; ripens early and is a good keeper. 


\section{Gooseberries}

This fruit is very useful for cooking either green or ripe and is used for canning extensively. Requires the same cultivation and treatment as Currants.

Champion (Oregon). Berries medium size, round, smooth, greenish-white with thin and transparent skin; good quality, ripens early; bush vigorous and very free from mildew.

Downing. Large and round, light green, with distinct veins; fruit is soft, juicy and finely flavored; vigorous and productive variety; skin smooth. One of the best.

Houghton. Size medium, pale red, sweet and juicy; is a vigorous grower, abundant bearer and free from mildew.
Industry. One of the best English varieties yet introduced; berries very large, dark red, hairy, rich and agreeable; bush vigorous and a great producer.

Pearl. Similar to Downing, but fruit a little larger, very hardy, free from mildew and very productive. Valuable for home use or market.

Smith's improved. Bush moderately vigorous, very productive; fruit large, pale yellow, thin skin. Excellent for dessert or cooking.

\section{Quinces}

The Quince is attracting a good deal of attention as a market fruit. The tree is hardy and compact in growth and requires little space; is productive, gives regular crops and comes into bearing early; the fruit is much sought for canning. When put up in the proportion of one quart of quinces to about four quarts of other fruit, it imparts a delicious flavor. It will grow in any good garden soil, which should be kept mellow, and well enriched. Fruit should be thinned out if it bears too freely.

Champion. Very large and handsome; flesh cooks as tender as an apple without hard spots; flavor delicate; tree very handsome and bears abundantly; valuable sort; greenish-yellow.

Meech's Prolific. Very large, bright yellow; quality very good and quite fragrant; bears early and is very productive; one of the best varieties. Mid-season.

Orange. Large, roundish, somewhat irregular with a small and short neck at the base; fine golden-yellow flesh and of excellent flavor. October.

\section{Mulberries}

The Mulberry is valued as an ornamental shade tree and the fruit is quite popular in some sections. Should be planted in deep, rich sandy loam. Requires little care and is of easy culture. The fruit is sprightly and refreshing and is a valuable addition to any fruit garden.

Downing's Everbearing. A beautiful tree for the lawn or street; bears an abundant supply of sweet, refreshing fruit for several weeks; berries are about one and one-half inches long; color blue-black.

New American. Equal to Downing in all respects and a much hardier tree; vigorous grower and very productive; ripe from middle of June until September; color black.
Russian. A very hardy rapid-growing, limber tree of great value, especially in the West; foliage abundant and said to be very desirable for silk worm culture; fruit good size and produced in large quantities. Introduced into this country by the Mennonites.

White. This is the variety used most for feeding silk worms; it forms a very large spreading tree.

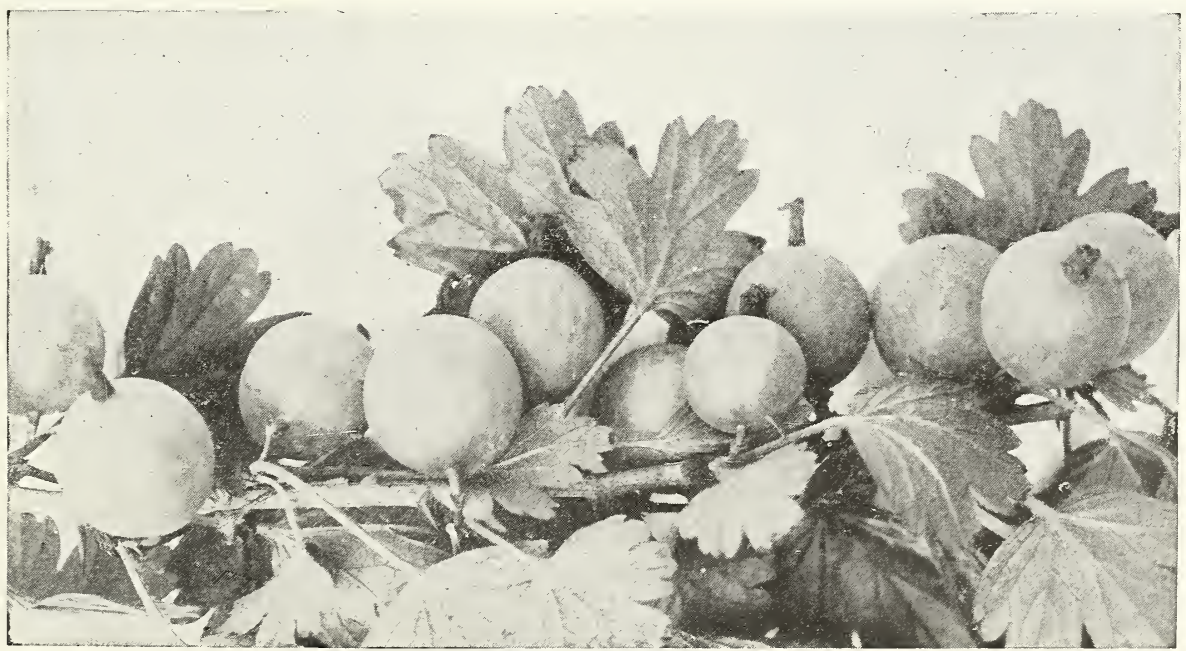

Pearl Gooseberry 


\section{Rhubarb}

This very desirable vegetable comes early in the spring. The large stems of the leaves are used for pie-making and stewing. It is álso valuable for medicinal purposes. A deep, rich soil is indispensable to secure large, heavy stalks. Plant in rows four feet apart, with the plants three feet distant. Set so that crowns are about one inch below the surface. Top dress in the fall with stable manure and fork under in the spring.

Linneaus, This variety produces a small stem. fine quality; early; excellent for cooking.

Victoria. Very large and valuable for market. Early.

\section{Asparagus}

This delicious and healthy vegetable should be found in every garden. Nothing can be more easily grown and no plant gives such a healthful food for such little outlay. Set in the fall or spring with the crown of the plant about three inches below the surface of the ground. Ten to twelve inches by two feet is a good distance to plant.

Barr's Mammoth. The largest of all, is very early, and quite tender and delicious; light color. The yield is simply enormous.

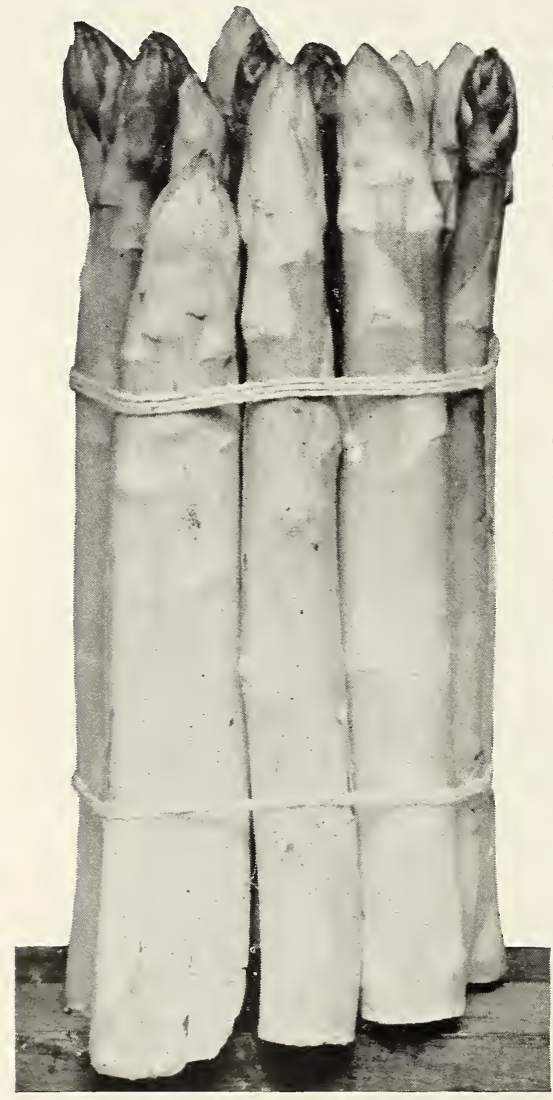

Barr's Mammoth Asparagus
Columbian. A distinct variety of mammoth size, great yield and superior quality. Remarkable for the clear whiteness of its stalk, which retains the clearness of its color until several inches high.

Conover's Colossal. A standard kind of firstclass quality. Tender and high flavored; valuable market and garden sort.

Palmetto, Extensively grown for market on account of earliness, large size and fine appearance.

\section{Nut Trees}

There has been more attention paid to the planting of nut trees the last few years than ever before. Few farms but contain land that, if planted to nutbearing trees, would pay better than anything else to which it could be devoted. Besides the value of the wood for commercial purposes, the crop of nuts of nearly all kinds commands high prices in market.

Butternut (White Walnut). A native of the Eastern states. It is a beautiful growing tree and yields a large nut with a rough hard shell within which are full white oily kernels, sweet, rich and of the most delicate flavor; tree has a wide spreading head, reddish colored, dark foliage; is a native of this country and adapted to nearly all sections.

Chestnuts (American Sweet). The American Sweet Chestnut is much superior to both the European and Japanese kinds, although it does not as yet approach in size to either of them. Chestnuts are much easier to propagate than other nut trees and come into bearing earlier. It does not do well in limestone or clayey soils, or in wet boggy land. The nut is sweet and well flavored: makes a valuable shade tree for either street or lawn.

Chestnuts (American Sweet). The American Sweet Chestdwarf grower, productive, usually producing nuts when two or three years old. Nuts of immense size, far surpassing all other kinds; of fair quality when outside skin is removed.

\section{PECANS}

Good budded or grafted trees of good prolific varieties properly planted and cared for under proper conditions, usually begin to bear a few nuts in five or six years after planting, and should produce a profitable crop in eight or ten years from planting, after which yield should be abundant for many years.

The Pecan is a very deep-rooted, hardy, long-lived tree, and is infested with fewer insect pests or diseases, perhaps, than any other fruit or nut tree of anything like equal importance; and when planted on land naturally rich and moist, the tree will thrive with little care or attention after well established, but there is no tree that responds more liberally to good treatment.

\section{WALNUTS}

Black Walnut (Juglaus Nigra). This species is a common and stately forest tree in the Middle and Western states; grows from forty to sixty feet high; has an open, spreading head and is rapid in growth; produces large crops of nuts with rough hard shell containing rich oily kernels of fine flavor.

\section{Japanese Varieties}

Sieboldiana. If it produces no nuts, it would be well worth cultivating as an ornamental tree; is a vigorous grower and produces nuts borne in clusters of 12 to 15 each; has a smooth shell, thicker than the English, much resembling pecans; meat is sweet and good flavor; tree is perfecly hardy. 


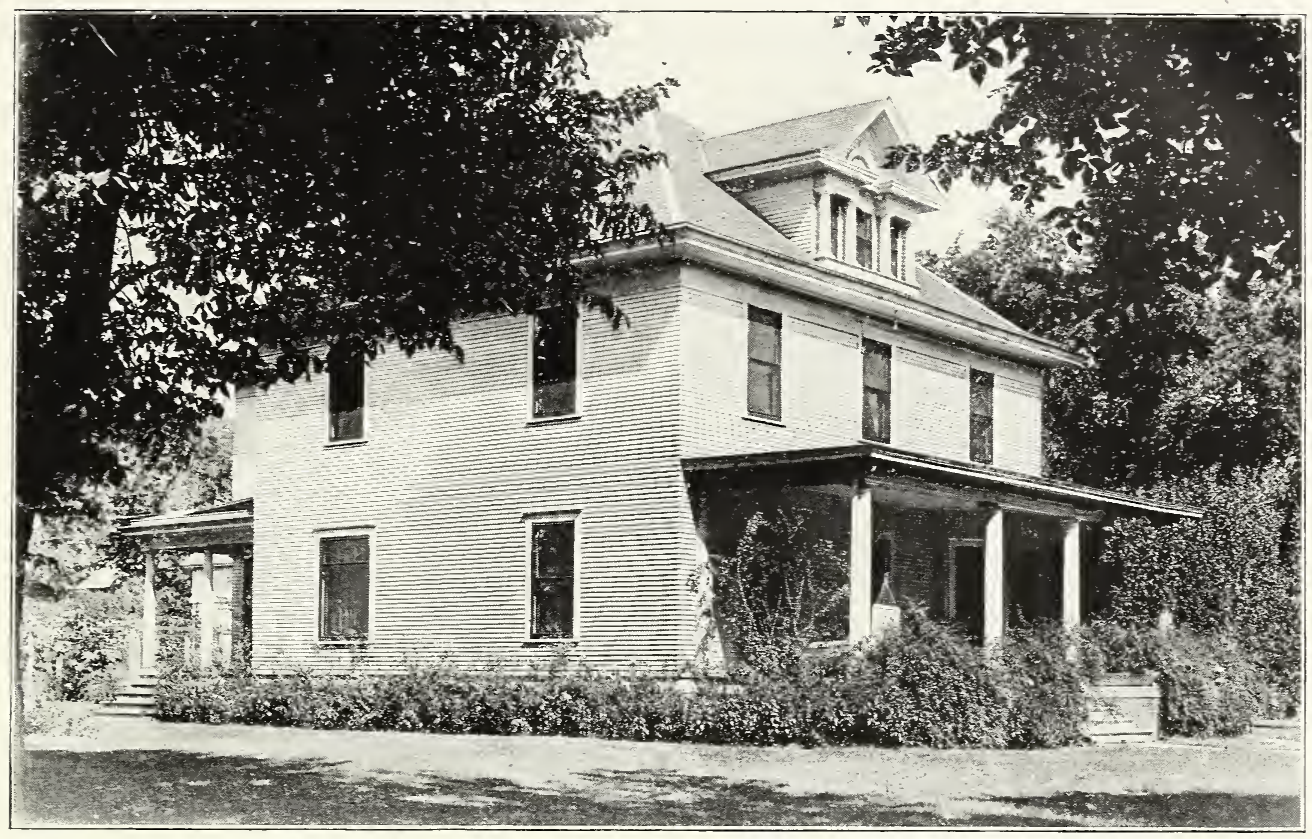

A York home showing the pleasing effect of proper banking of shrubs near the foundation.

\section{Ornamental Department}

If the grounds surrounding the house are extensive, beautiful effects can be produced by planting shade trees, shrubs, vines and flowers according to some pre-arranged plan. To give your home an inviting approach, the trees and shrubs should not be planted at random. A well cut lawn with shrubs planted near the foundation of the residence, a few ornamental trees planted in an appropriate place, along the drives leading to the house and other buildings, bespeak the spirit and character of the home. Open lawn treatment is very artistic, and gives a picture of expression. Vines trained over porches, trellises, fences, etc., can be made very effective at a small cost. Real estate owners who have vacant property to sell are beginning to plant fine trees and shrubs, knowing that they can secure a larger percentage on their investment, as purchasers will pay more for a fine looking lot than one given over to unsightly surroundings. We would also emphasize the fact that you should buy none but the best. A little thought will convince you that it is not the quantity, but the quality that counts. Buy none but the best stock, properly grown by reliable nurserymen, who have given their best thought to the careful propagation and best varieties. We have a large stock of all kinds of shade tree, ornamental shrubs, etc., that has been selected with the greatest care and attention, both as to variety and quality.

\section{HOW TO PLANT}

A fine, well-cut lawn is one of the handsomest features of a place. Trees and the larger shrubs may be planted along a lane or avenue leading to the house, or dotted about the lawn on lines radiating from it. This will secure light, air and a good view from the house. In laying out the grounds, take into consideration economy in labor, and make as few walks as possible. Upright shrubs, roses and flowers should be planted in clumps, each kind by itself, and aroid making the lawn look like a checker board. These beds should be well cultivated and the plants pruned annually. Mass the trees and beds on the boundaries so as to leave a broad space for the lawn, and where there is a pretty view leave an opening. Where there is an unsightly object, conceal it by planting trees or climbing vines. Do not plant large trees near the house, except enough on the sunny side for shade.

Plant shrubs and small trees twice as thick as they should be when fully grown. This will make a good showing at once, and when the growth of the plants has made them too thick, some should be taken out. It will not do to plant so little that years must elapse before a fine effect can be produced, but, by planting a surplus at first, they can gradually be taken out.

\section{VINES}

Should be planted near to and allowed to climb upon and about the house, or trained on posts, trellises, arbors or stakes placed in suitable locations on the lawn.

Groups of trees and shrubs possessing bright-colored bark or foliage, and groups of flowering trees and shrubs, are highly effective when in blossom and should be more generally planted.

Weeping trees are especially desirable on small lawns. 


\section{NEW VARIETIES}

We are constantly adding to our list of ornamentals, as well as in other departments. Before placing new varieties on the market, we give them a thorough trial in the nursery, and thus weed out undesirable varieties, offering only the best in each class.

\section{VARIETIES NOT LISTED}

In every large, well-conducted nursery there are many varieties of extra size, but in too small quantities to list in the catalog; also new varieties which have not been thoroughly tested. If you wish any variety in a special size or variety not listed, write to us for special quotations, and if we have it in stock, we shall be pleased to supply.

\section{Evergreens}

\section{ARBOR VITAE. Thuya}

American Arbor Vitae (T. Occidentalis). A beautiful native tree commonly known as the White Cedar; valuable for screens and hedges.

Chinese Arbor Vitae (T. Orientalis). The hardiest for the West.

\section{BOXWOOD}

Boxwoods are used for grouping, edging, walk planting, against foundations, hedges, for tubbing, and also for formal gardens, terraces and porches. Should be protected during winter.

\section{FIR. Abies}

Abies Tsuga Canadensis (Hemlock). A native species of undoubted worth and beauty. Entirely hardy, with drooping branches and dense habit.

Balsam Fir (A. Balsamea). A very erect, regular pyramidal tree with dull, dark green foliage; rapid growth and very hardy.

Concolor Fir (A. Concolor). A very beautiful species with yellow bark on the young branches; leaves green, arranged in double rows; equal in color and beauty to the Colorado Blue Spruce.

\section{JUNIPER. Juniperus}

Juniper Glauca (Silver Cedar). Fine vigorous grower; cone-shaped; of a peculiar whitish color.

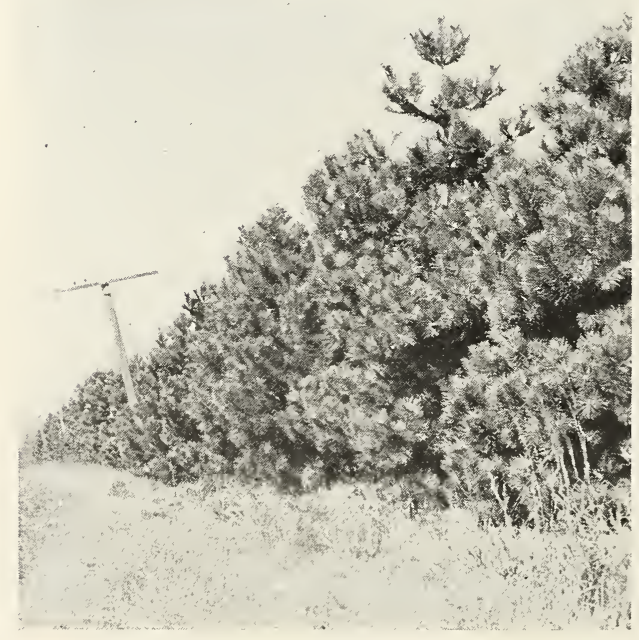

Austrian Pine wind-break on our nursery grounds

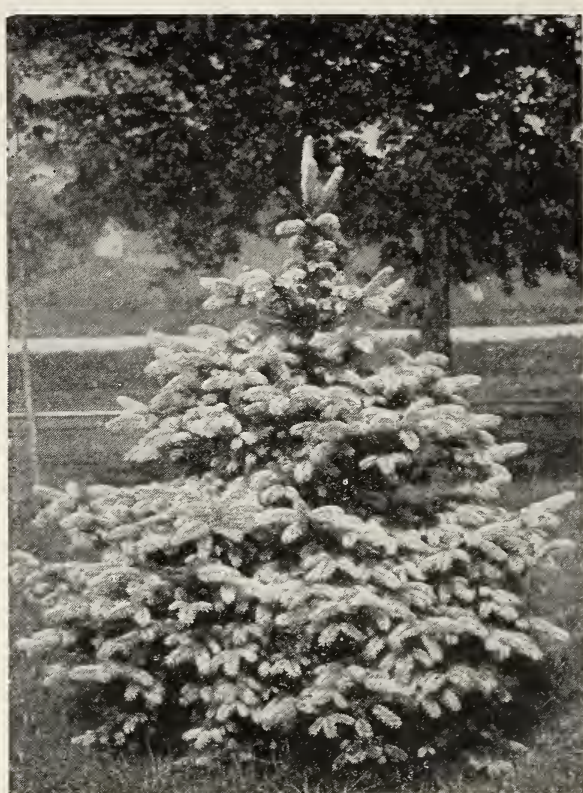

Koster's Blue Spruce

Swedish Juniper (J. Communis, var. sueciea). A small sized, handsome pyramidal tree with yellowish-green foliage; quite hardy.

PINE. Pinus

Austrian or Black Pine (P. Austriaca). A native of Syria; tree robust, hardy and spreading; leaves long, stiff and dark green; rapid growth; very valuable for this country.

Bull Pine (P. Ponderosa, var. Scopulorium). Forms a stout, spreading tree; a rapid grower; branches heavy and rough coated with bark; foliage dark green, the needles growing out at right angles to the wing; very hardy.

Jack Pine (P. Divaricata). The most northern of all American pines; valued for its extreme hardiness and vigor; withstands long drouths and hot dry winds; of rather irregular and shrubby growth; foliage bright green, needles short and stiff.

Scotch Pine (P. Sylvestrus). A native of Europe a fine, robust, rapid-growing tree with stout, erect shoots and silvery-green foliage; very hardy.

White Pine (P. Strobus). The most ornamental of all our native pines; foliage light, delicate silvery green; will grow in the poorest of sandy soils. A long-lived tree and rapid grower.

Pinus Mugho (Dwarf Mountain Pine). Very distinct, leaves short, stiff, a little twisted and thickly distributed over the branches; does not grow tall, but spreads over the ground, generally assuming a globular form; very dense.

\section{SPRUCE. Picea}

Black Hills Spruce (P. Nigra). A beautiful tree with drooping branches and fine yew-like foliage; perfectly hardy

Colorado Blue Spruce (P. Pungens). One of the most beautiful and hardy of all the spruces; in form and habit similar to the White Spruce; foliage a rich light bluish-green. 
Douglas' Spruce (A. Douglasii). A native of Colorado; large, conical form; branches spreading, horizontal; leaves light green above, silvery-white below.

Englemann's Spruce (P. Engelmanni). Resembles the Colorado Blue Spruce in general effect; foliage coloring from bluish-green to steel blue; needles are not as long and are more soft and flexible.

Koster's Blue Spruce (P. Pungeris, var. Kosteriana). A type of the Colorado Blue Spruce; it is the highest colored and most striking of all the Evergreens for lawn planting; the foliage is a rich and beautiful silvery-blue; very hardy.

Norway Spruce (A. Excelsa). From Europe. An elegant tree; extremely hardy, of lofty, rapid growth and pyramidal form. The branches assume a graceful, drooping habit when the tree attains 15 to 20 feet in height. One of the most popular evergreens for planting, either as single specimen trees, or in masses for effect or shelter. It is one of the best evergreen hedge plants.

White Spruce (P. Alba). A native tree of medium size and pyramidal form; bark light colored and foliage silvery-gray; very hardy.

\section{Upright Deciduous Trees}

\section{AILANTHUS. Tree of Heaven}

A. Glandulosa, From Japan. A lofty, rapid-growing tree, with long, elegant, feathery foliage, free from all diseases and insects. One of the most distinct of ornamental trees.

\section{ALNUS, Alder}

European or Common Alder (A. Glutinosa). A remarkably rapid-growing tree, attaining a height of from 30 to 60 feet. Foliage roundish, wedge-shaped and wavy. This species is specially adapted to moist situations.

Imperial Cut-Leaved Alder (Var. Laciniata Imperialis). A stately tree, of graceful habit, with large and deeply laciniated foliage; at the same time vigorous and perfectly hardy. Unsurpassed as a lawn tree.

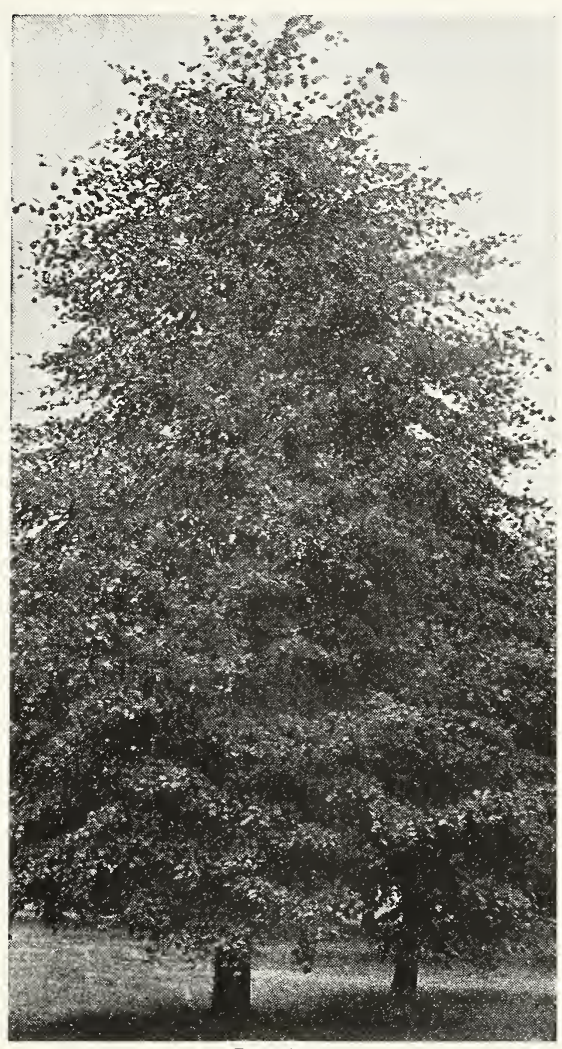

Linden

ASH. Fraxinus

American White Ash (F. Americana). A wellknown native tree; tall, very straight, with broad, round head and dense foliage. (See Common Shade Trees.)

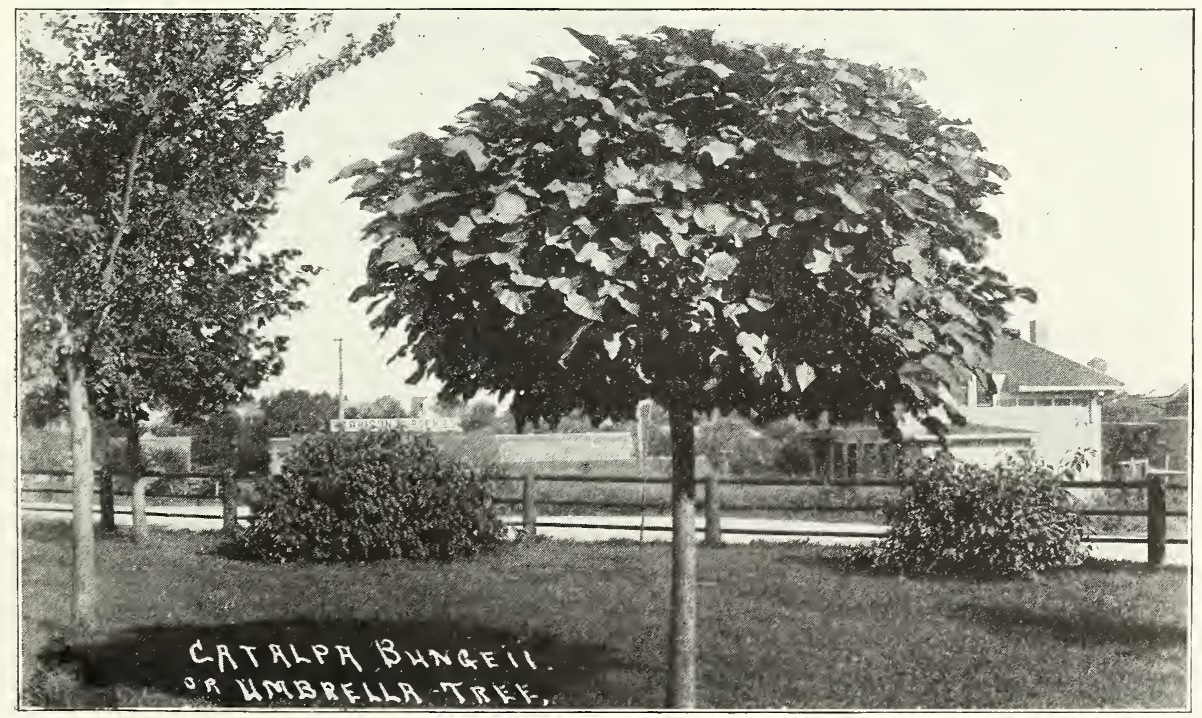


European Ash (A. Glutinosa). A lofty tree of rapid growth, with spreading head and gray barred pinnate leaves and black buds.

Green Ash (F. Lanceolata; F. Viridis). A tree of medium size with slender, spreading branches forming a shapely round head; grows 50 to 60 feet high.

\section{BEECH. Fagus}

American Beech (F. Ferruginea). A large, stately native tree with smooth bark, spreading branches and symmetrical head; grows 80 to 100 feet high; one of the handsomest trees for lawns or streets.

Purple-Leaved Beech (F. Purpurea). Originated in Germany. An elegant, vigorous tree, growing 50 to 60 feet high; foliage in spring is a deep purple, changing to crimson in the fall.

\section{BIRCH. Betula}

European White Birch (B. Alba). Remarkable for its elegance. A graceful tree with silvery bark and slender branches; quite erect when young, but afterwards assumes an elegant drooping habit, rendering it very effective for landscapes or lawns.

Purple-Leaved Birch (B. Atropurpurea). A variety possessing the vigorous habit of the birches and having purple foliage; branches slightly pendulous.

\section{CATALPA}

Kindly note what Mr. Happel has to say about the Catalpa.

Harrison Nursery Co., York, Nebr.

Gentlemen: I will say that it is a good investment for any farmer that has his own land to put out some of the Catalpa trees. We have ten acres of them and cut every winter from two to three hundred dollars worth of posts and poles. Farmers who know what Catalpa fence posts are will buy them in preference to any other. We also sell poles from ten feet up to telephone poles. This will show my experience with Catalpa trees.

Yours truly, Henry Happel, Hebron, Nebr.

Chinese Catalpa (C. Bungei). A remarkable species forming a dense, round, umbrella-like head; makes a beautiful lawn tree when grafted or budded on a high stem.

Hardy Catalpa (C. Speciosa). A variety which is said to have originated in the West; it is very hardy and a rapid grower and is being extensively planted for commercial purposes; has broad deep green leaves and beautiful large blossoms, making it a highly ornamental tree for lawn or street. Valuable for planting in groves for growing poles, posts and railroad ties.

\section{CHERRY. Cerasus}

Common Wild Bird or Pin Cherry (C. Pennsylvanica). Suited to rocky, sandy and poor soils. White flowers and bright red fruits that attract birds.

Double White Flowering Cherry (C. Avium, alba flore pleno). At period of flowering in May is a beautiful and attractive tree; the flowers are numerous and present to the eye nothing but a mass of bloom; raluable variety.

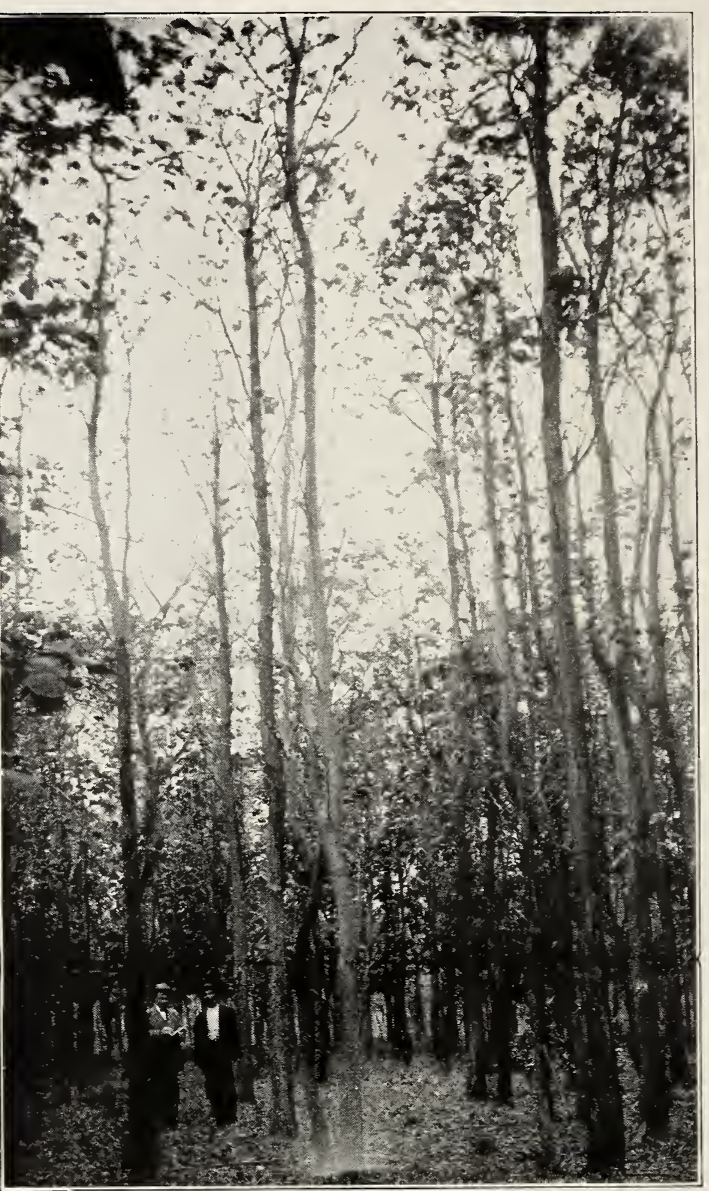

Hardy Catalpa Grove of Henry Happel, Hebron, Nebr.

\section{CHESTNUT. Castanea}

American Sweet Chestnut (C Americana). The well-known variety. A stately tree with spreading head; when in full bloom, one of the handsomest trees; produces a quantity of edible nuts.

\section{CHESTNUT, HORSE. Aesculus}

Common or White Flowering (A. Hippocastanum.) A handsome tree of regular form with showy foliage and covered in the spring with panicles of white flowers marked with red. As a lawn or street tree it has no superior.

Double-Flowering Horse Chestnut (A. H. var. alba flore pleno). A superb tree with double white flowers in large panicles and of fine pyramidal habit; it is one of the best of the ornamental trees.

Ohio Buckeye (A. Glabra). A native of the Western states forming a large sized tree; leares are smooth and the flowers yellow; blooms before other varieties.

Red Flowering Horse Chestnut (A. H. rar. rubicunda). One of the finest trees in cultivation; flowers a showy red; blooms a little later than the white; when the two varieties are planted together they make a very effective contrast. 


\section{CRAB. Pyrus}

Bechtel's Double-Flowering Crab (P. Angustifolia). One of the most beautiful of the flowering crabs; tree of medium size, covered in early spring with large, beautiful fragrant flowers of a delicate pink color; very popular for lawns, as it blooms when quite young.

\section{DOGWOOD, Cornus}

Red-Flowering Dogwood. A variety producing flowers suffused with bright red; blooms when quite young. One of the finest flowering trees.

White-Flowering Dogwood (C. Florida). Grows from 20 to $\mathbf{2 5}$ feet high; spreading, irregular form; flowers produced in spring before the leaves appear, about $3 \frac{1}{2}$ inches in diameter, white and showy; very durable, lasting two weeks; foliage is a grayish-green, glossy and handsome, turning to a deep red in the fall. A valuable tree for ornamental planting.

\section{ELM. Ulmus}

American White Elm (U. Americana). A magnificent tree growing 80 to 100 feet high, with drooping, spreading branches; one of the grandest of our native trees; makes a beautiful lawn or street tree. (See Common Shade Trees.)

English Elm (U. Campestris). An erect, lofty tree of rapid, compact growth, with smaller and more regularly cut leaves than the American; the branches project almost at right angles, giving the tree a noble appearance.

Huntingdon Elm (U. Huntingdoni). A very handsome tree of erect habit, rapid, vigorous growth; bark clean and smooth. One of the finest of this family.

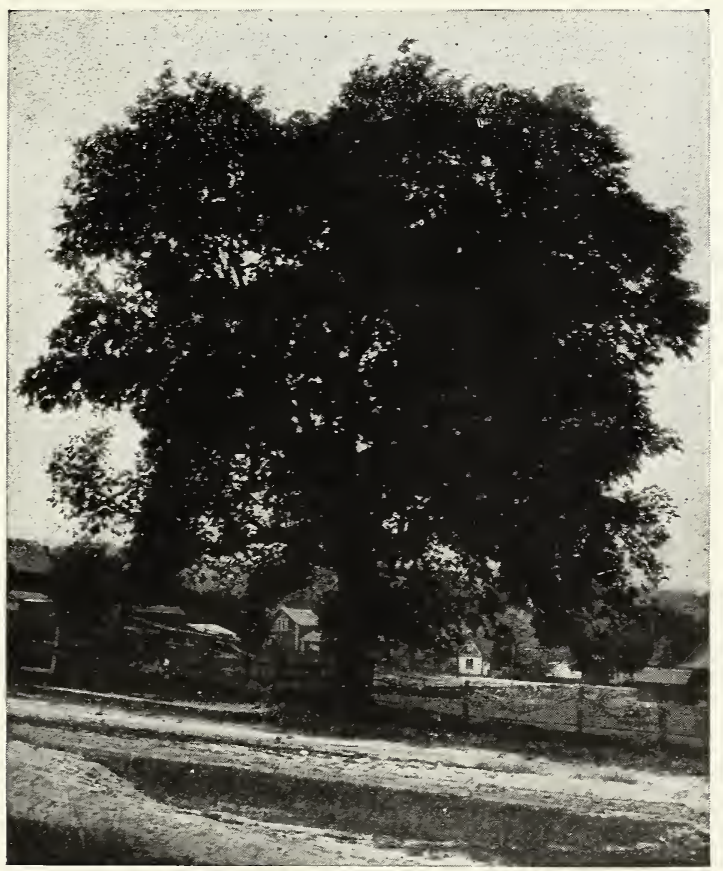

American White Elm
Purple-Leaved English Elm (Var. Stricta Purpurea). A striking variety with erect branches and purple leaves.

Red or Slippery Elm (U. Fulva). Not so large as the American; foliage larger and head more open; inner surface of bark used extensively for medicinal purposes.

\section{HACKBERRY. Celtis}

American Nettle Tree (C. Occidentalis). A rare native tree with numerous slender branches which spread horizontally, and thick rough bark; applelike foliage, but more pointed and a bright shiny green; a very desirable tree for street planting.

\section{KENTUCKY COFFEE TREE. Gymnocladus}

A very ornamental, hardy tree of upright, rapid growth with rough bark and coarse branches; foliage of a bluish-green color; flowers white followed by long pods. The name coffee tree comes from the fact of the seeds in the pods having been used by early settlers as a substitute for coffee.

\section{LARCH. Larix}

American Larch (L. Americana). A tall tree, forming a prramidal head; bark reddish-brown, branches slender; leaves long and slender, of a light blue color; canes small and oval; makes a very beautiful lawn tree and is also serviceable as a windbreak.

European Larch (L. Europea). A native of the Alps of the south of Europe; an elegant growing, pyramidal tree. Valuable for timber.

\section{LINDEN. Tília}

American Linden or Basswood (T. Americana). Grows about 60 feet high, rapid growing, large size, forming a broad round-topped head; leaves broadly oval, dark green above, light green underneath; flowers are creamywhite and fragrant; a splendid street or lawn tree.

European Linden (T. Europea). A very fine pyramidal tree of large size with large leaves and fragrant flowers; the leaves change in the fall to beautiful tones of yellow and brown.

European Broad-Leaved Linden (T. var. platiphylla). A tree about the same size as above, but distinguished by its larger and rougher leaves and more regular growth.

Silver-Leaved Linden (T. Argentea). Showy, heart-shaped foliage, light green above and silvery underneath; grows about 40 feet high; its handsome form and foliage make it one of the best of our ornamental trees.

\section{LOCUST, Gleditschia}

Honey Locust (G. Tricanthos). A rapidgrowing native tree with powerful spines and delicate foliage; the greenish flowers appearing in early summer are followed by flat pods 8 to 10 inches long; used extensively for hedges. 


\section{LOCUST or ACACIA. Robinia}

Black or Yellow Locust (R. Pseud-acacia). A native tree of large size, rapid growth and valuable for timber as well as ornamental; flowers are white or yellowish, very fragrant and appear in June.

\section{MAGINOLIA}

Cucumber Tree (M. Acuminata). A majestic pyramidal tree growing to a height of 90 feet with large bluish-green leaves 6 to 8 inches long; flowers yellowishwhite; fruit when green resembles a cucumber.

Soulang's Magnolia (M. Soulangeana). A large shrub or small tree; leaves dark green, expanding after the flowers have fallen; flowers large cup-shaped, white flushed with rosy pink and quite fragrant.

\section{MAPLE. Acer}

Box Elder or Ash-Leaved Maple (A. Negundo). Large spreading tree of rapid growth, 70 feet high; foliage is smaller than in other maples; very frequently planted for windbreaks and timber; very hardy. (See Common Shade Trees.)

Norway Maple (A. Platanoides). A large, handsome tree, with broad, deep green foliage; has a very compact growth; attains a height of 100 feet; a valuable tree for parks, lawns or streets.

Schwedlers Maple (A. Platanoides Schwedlerii). A beautiful variety with very large bronze-red leaves and young shoots of the same color; a vigorous grower and a most effective ornamental tree; grows about 50 feet high.

Silver-Leaved or Soft Maple (A. Dasycarpum). A rapid-growing tree of large size, irregular round-

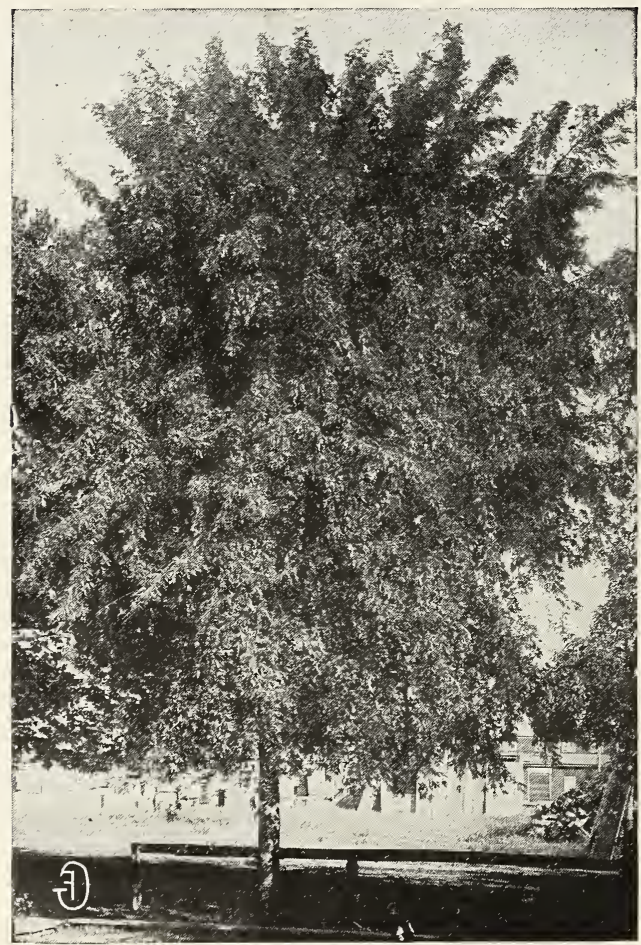

Wier's Cut-Leaved Maple

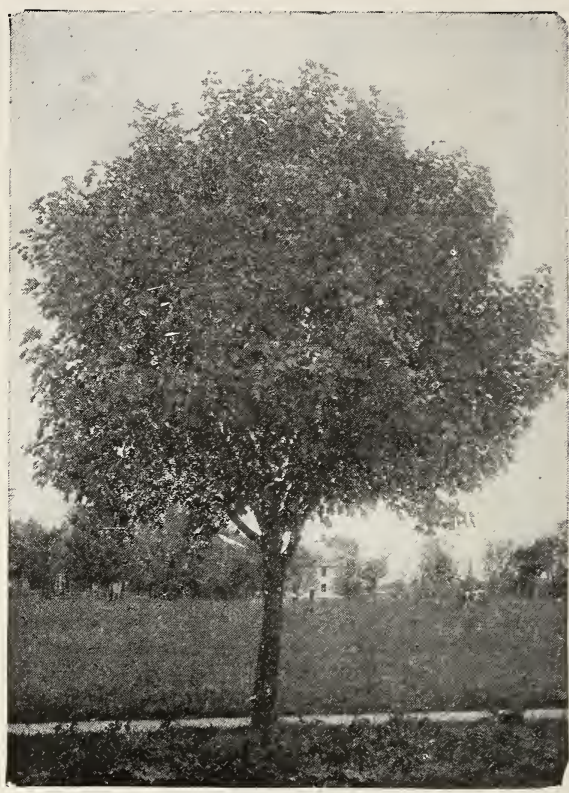

Norway Maple

ed form; foliage bright green above and silver beneath; a favorite street and park tree; attains about the same height or taller than the Norway. (See Common Shade Trees.)

Sugar or Hard Maple (A. Saccharum). A wellknown native tree, valuable both for the production of sugar and wood. Very desirable as an ornamental shade tree.

Wier's Cut-Leaved Maple (A. Wierii Laciniatum). A variety of the silvery-leaved and one of the most beautiful with cut or dissected foliage; rapid growth, shoots slender and drooping. Ranks among the best as an attractive lawn or street tree.

\section{MOUNTAIN ASH. Sorbus}

European Mountain Ash (S. Aucuparia). A fine tree with dense and regular head; covered from mid-summer to winter with great clusters of bright scarlet berries.

Oak-Leaved Mountain Ash (S. Quercifolia). A hardy tree of fine pyramidal habit; foliage deeply lobed, bright green above and downy underneath. One of the finest lawn trees.

\section{MULBERRY。 Morus}

Russian Mulberry M. (Alba Tartarica). See Mulberries, page 23.

White Mulberry (M. Alba). See Mulberries, page 23.

\section{OLIVE. Eleagnus}

Russian Olive (E. Augustifolia). A very large shrub or small tree; leaves narrow and silverywhite, flowers yellow and fragrant; very hardy.

\section{OAK. Quercus}

Black Oak (Var. Tinctoria). Beautiful colored foliage in autumn.

Chestnut Oak (Q. Prinus). One of the finest species; leaves resemble those of the Chestnut. 


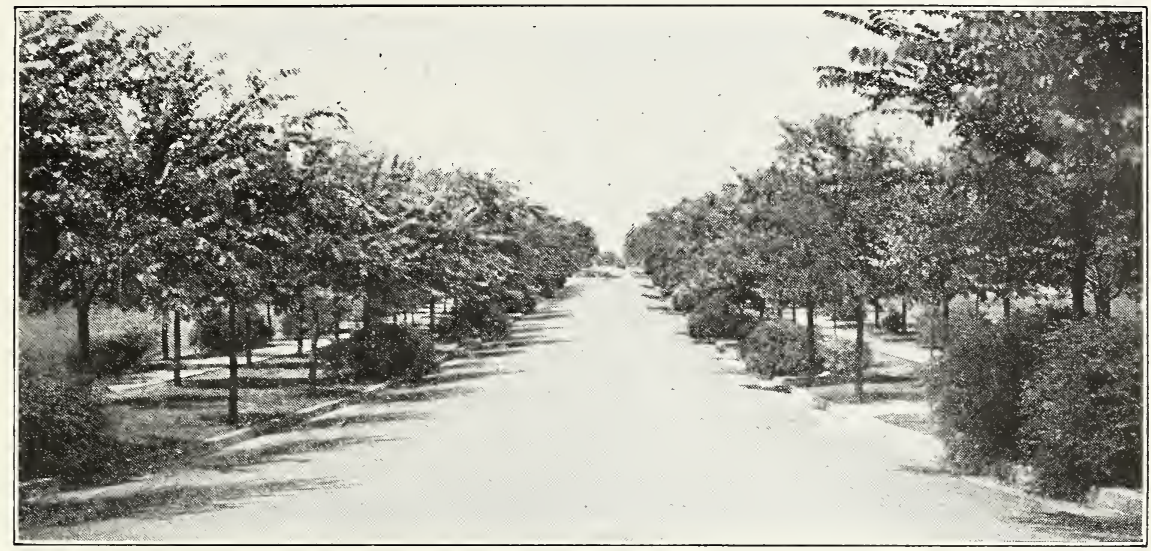

Rows of trees and artistic arrangement of shrubs and flowers not only enhance the beauty of your city and home, but add to the commercial value of same.

Mossy Cup or Bur Oak (Q. Macrocarpa). Native tree of spreading form. Foliage deeply lobed, and the largest and most beautiful among oak leaves. Cup-bearing, acorn-fringed and bur-like. Bark corky. One of the noblest of the family.

Pin Oak (Q. Palustris). A magnificent tree for lawn and street planting, with deep green foliage which changes to a rich scarlet and yellow in the fall. A most shapely and graceful tree.

Red Oak (Q. Rubra). Makes a tree of great height, 80 to 100 feet; a native of large size and

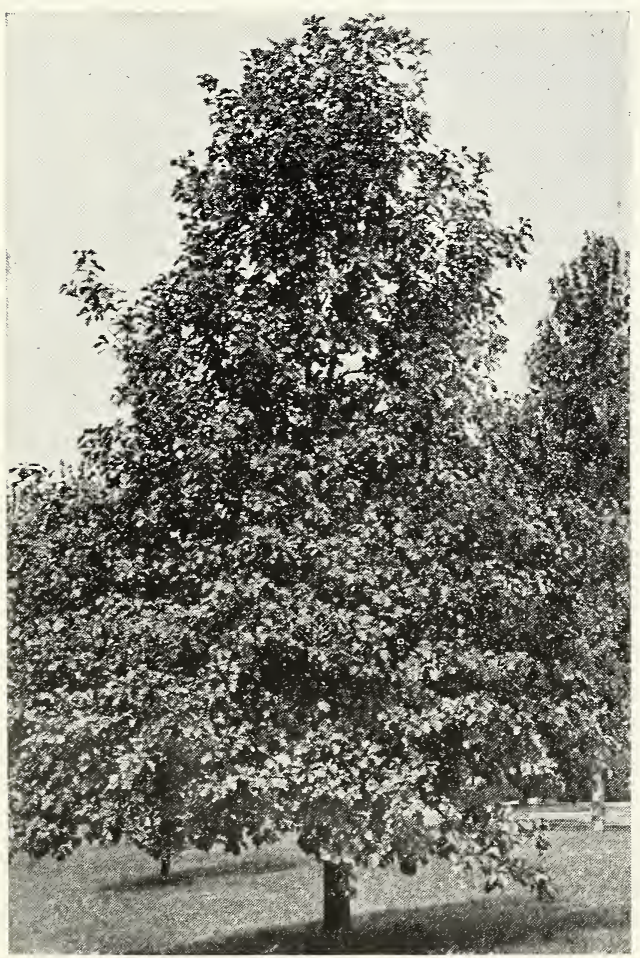

Pin Oak rapid growth; leaves dark dull green, turning to orange and brown in autumn; acorns very large; a beautiful specimen tree for park and street planting.

Scarlet Oak (Q. Voccinea). A rapid-growing pyramidal tree, especially beautiful in the fall, when the foliage changes from green to a bright scarlet. Very symmetrical in outline.

\section{PERSIMMON. Diospyros}

American Persimmon (D. Virginiana). A native variety with round top head and spreading, often pendulous branches; foliage dark green and very dense, fruit over an inch in diameter, pale orangeyellow, with a whitish bloom; delicate flower; very astringent until full ripe or after early frosts. Makes a beautiful lawn tree.

\section{PLUM. Prunus}

Double-Flowering Plum (P. Triloba). A charming shrub or small tree, 3 to 5 feet high, of spreading, vigorous growth. Very early in spring before its leaves appear the whole tree is decked in a fleecy cloud of very double, light pink blossoms. Its effect on a still leafless landscape is very bright.

Hanson's Purple Plum. Tree of beautiful foliage, much resembling the Pissardi, the hardiest of all purple plums.

Purple-Leaved Plum (P. Pissardi). Tree of medium size, wood and leaves dark purple; fruit is also purple until ripened; a native of Persia. One of the most conspicuous ornamental trees.

\section{POPLAR, Populus}

Balm of Gilead (P. Balsamifera Candicaris). A strong growing spreading native tree; esteemed for its vigor and hardiness; leaves broad and heartshaped, green above and rusty white beneath; it makes a good street tree and is perhaps the best of the poplars for shade.

Carolina Poplar (P. Monolifera). Pyramidal in form and vigorous in growth; the leaves large, glossy, pale to deep green; valuable for street planting on account of its rapid growth. 
Norway Poplar or "Sudden Sawlog." This is just what people are looking fora tree that will get a move on itself and turn out lumber in the shortest space of time. Our forests are rapidly disappearing, and they must be replaced with some rapid-growing tree. The Norway Poplar promises to be to the North what the Eucalyptus is to the South. It is by far the most rapid grower we have. Slips planted at the experiment station at York, Neb., made trees 16 feet tall and 3 inches through at the base in two years. This tree does not, like many others, waste its energy in side limbs. It retains its size as it mounts upward and thus produces more lumber material than any other. It outgrows the cottonwood, the Carolina and Asiatic poplars, and in a succession of dry years will survive them all. Here we have a tree of tremendous growth retaining its size as it mounts upward, with large leaves waving like fans, in the breeze. This tree is well adapted to the Middle States and is a success in the North.

Silver-Leaved Poplar (P. Alba var. Nivea). A tree of wonderfully rapid growth and wide, spreading habit; leaves large, glossy green above and white underneath; prefers a moist soil, but grows anywhere.

\section{RED BUD. Cercis}

Judas Tree or Red Bud (C. Canadensis). A medium size tree with large irregular head and perfect heart-shaped leaves; derives its name Red Bud from the profusion of delicate reddish-pink blossoms with which it is covered in early spring before the foliage appears. One of the finest ornamental trees.

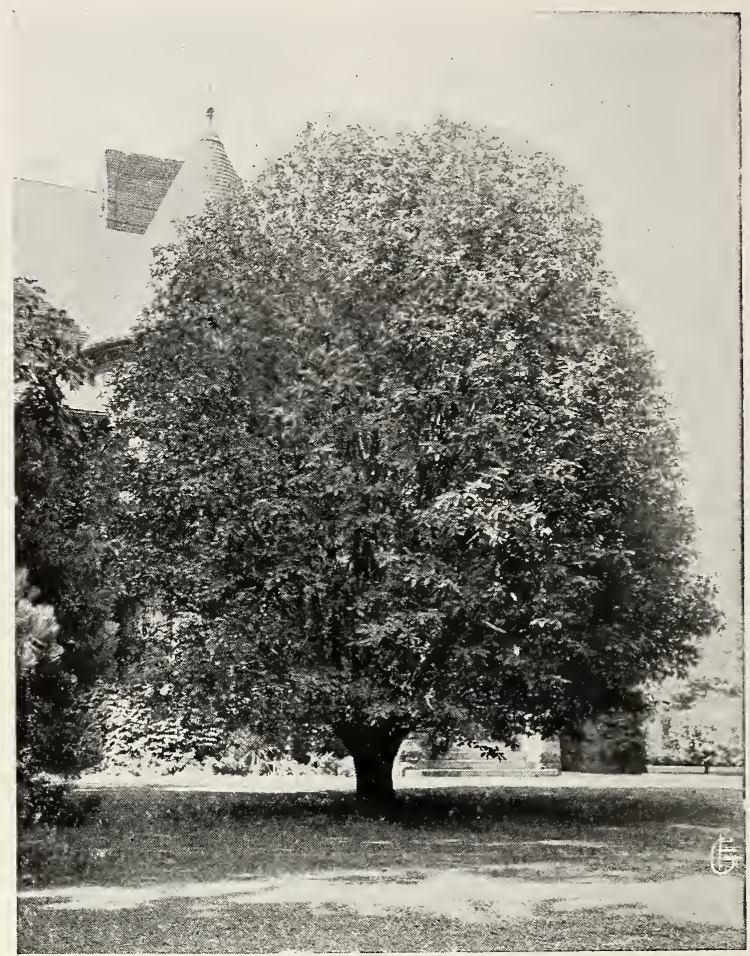

Mountain Ash

\section{SALISBURIA}

Madien Hair or Gingko (S. Adiantifolia). Very effective for lawns, foliage fern-like, yellowishgreen marked with delicate, hair-like lines. The fruits, which mature in the fall, have a sweetish, resinous taste.

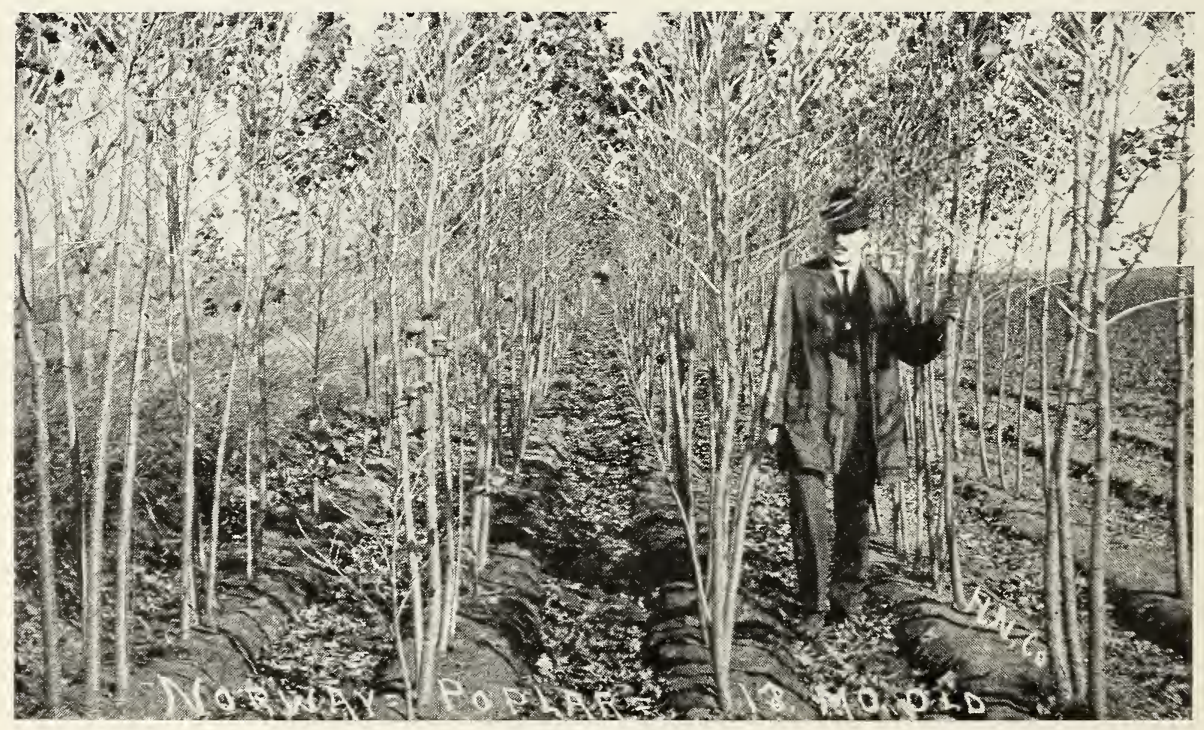

Norway Poplar 


\section{SYCAMIORE. Platanus}

American Sycamore or Plane Tree (P. Occidentalis). A well-known tree, very common throughout the United States; leaves heartshaped at base, the short lobes sharp pointed; branches are wide spreading.

Oriental Plane or European Sycamore (P. Orientalis). A rapid-growing, erect tree with bright green foliage; much more esteemed than the American variety as a shade tree; very desirable for parks, streets and lawns.

\section{THORN. Crataegus}

Double White Thorn (Oxyacantha, var. alba flore pleno). A small tree, with spreading, spiny branches; very hardy and will thrive in any dry soil; has small double, white flowers. A very highly ornamental tree.

Double Pink Thorn (C. Oxyacantha, var. rosea flore pleno). Same as above, but with flowers of a beautiful pink color.

English Hawthorne (C. Oxyacantha). The well-known English variety extensively used for hedges; flowers single white.

Paul's Double Scarlet (C. Oxyacantha, var. coccinea flore pleno). Flowers a bright carmine red; superior to any of its color.

\section{TULIP TREE. Liriodendron}

Tulip Tree (L. Tulipfera). A magnificent rapid-growing tree of pyramidal form, attaining a height of 150 feet, with light green, glossy fiddle-shaped leaves and greenish-yellow tulipshaped flowers; also known as white wood.

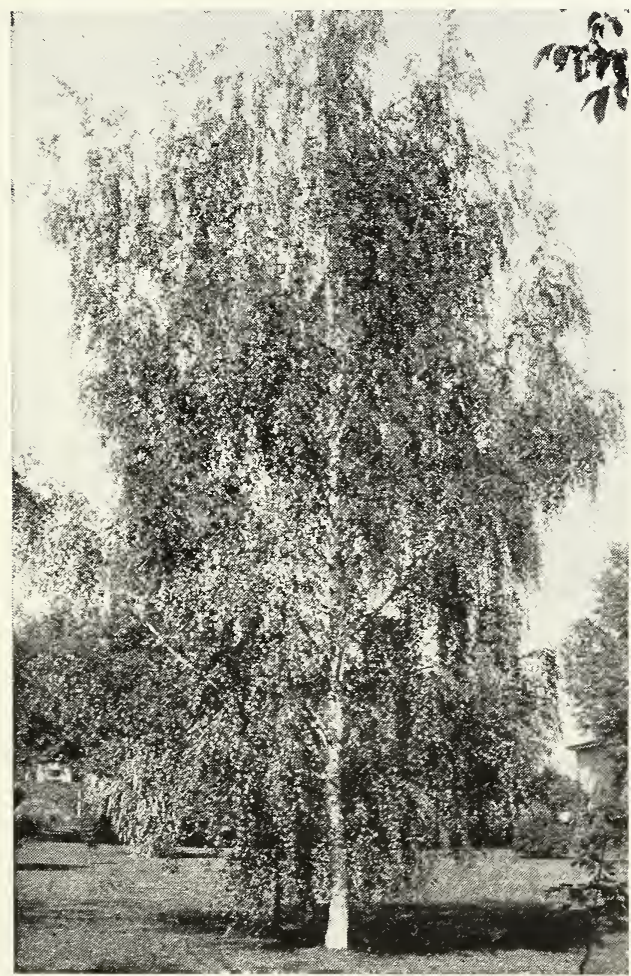

Cut-Leaved Weeping Birch

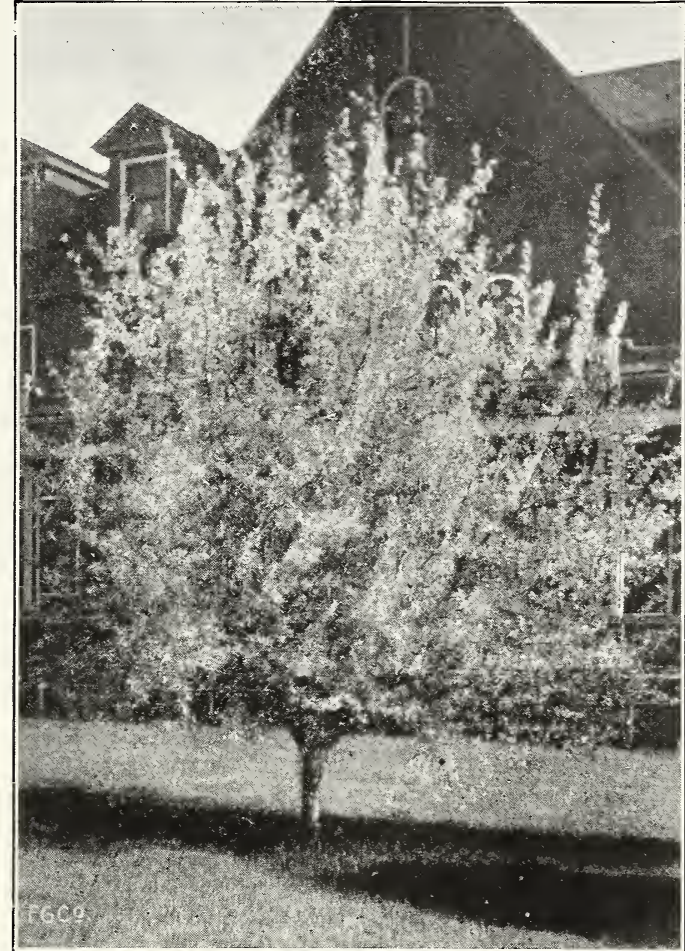

Russian Olive

WALNUT

Black. See page 24 .

\section{WILLOW. Salix}

Russian Golden (S. Vitellina aurea). At the present time one of the most planted of all the Willows and a very important tree, both from an economical and ornamental standpoint. It makes a round-topped tree of symmetrical form. One of its strongest ornamental features is the bright, clear, golden-yellow bark which offers a pleasing contrast wherever it is used. The variety which is now generally grown under this name is quite distinct from that to which it was formerly given. This type was brought from Russia by Prof. Budd, under the name of Salix Aurea, and it is superior not only for its hardiness, but for its ornamental features also.

Laurel-Leaved Willow (S. Laurifolia). Fine ornamental tree with very large shining leaves.

\section{SEEDLING TREES}

Elm, Ash, Box Elder, Maple, Russian Mulberry, Black Locust, Honey Locust and Russian Olive.

\section{Weeping Trees}

\section{BIRCH. Betula}

Cut-Leaved Weeping Birch (B. Alba, var. pendula laciniata). Undoubtedly one of the most popular of all weeping or pendulous trees; tall and slender, graceful drooping branches, silvery-white bark, delicately cut foliage; makes an attractive tree; vigorous. 


\section{ELM. Ulmus}

Camperdown Weeping Elm (U. Scabra var. pendula). This forms one of the most picturesque of the drooping trees; forms a large, umbrella-like head, spreading many feet in every direction; very rapid grower, making a growth of several feet in a season; leaves are large, dark green and glossy, and cover the tree with a dense mass of verdure.

\section{LINDEN}

Weeping Silver-Leaved. An elegant medium sized tree, 10 to 15 feet tall, of gracefully pendulous habit, that holds its large, silver-lined leaves through the season. Hardy, grows fast and is quite striking. 4 to 6 feet.

\section{MOUNTAIN ASH. Pyrus}

Weeping Mountain Ash (P. Sorbus Aucuparia, var. pendula). A beautiful tree of rapid growth and decidedly pendulous and trailing habit. One of the most desirable of lawn trees.

\section{MULBERRY. Morus}

Tea's Weeping Mulberry (I. Alba, var. tartarica pendula). One of the most graceful and hardy weeping trees; forms a perfect umbrella-shaped head with long, slender, willowy branches drooping to the ground; admirably adapted to ornamenting lawns or cemetery; the foliage is beautiful and the tree is wonderfully rigorous and healthy; will withstand the cold of the North, and the heat of the South; in every way a most desirable tree.

\section{WILLOW. Salix}

American Weeping Willow (S. Purpurea, var. pendula). A dwarf, slender variety; grafted 5 or 6 feet high, it makes one of the most ornamental of small weeping trees; it is more hardy than the Babylonica.

Babylonian Weeping Willow (S. Babylonica). The well-known, common weeping willow; makes a large tree covered with drooping branches.

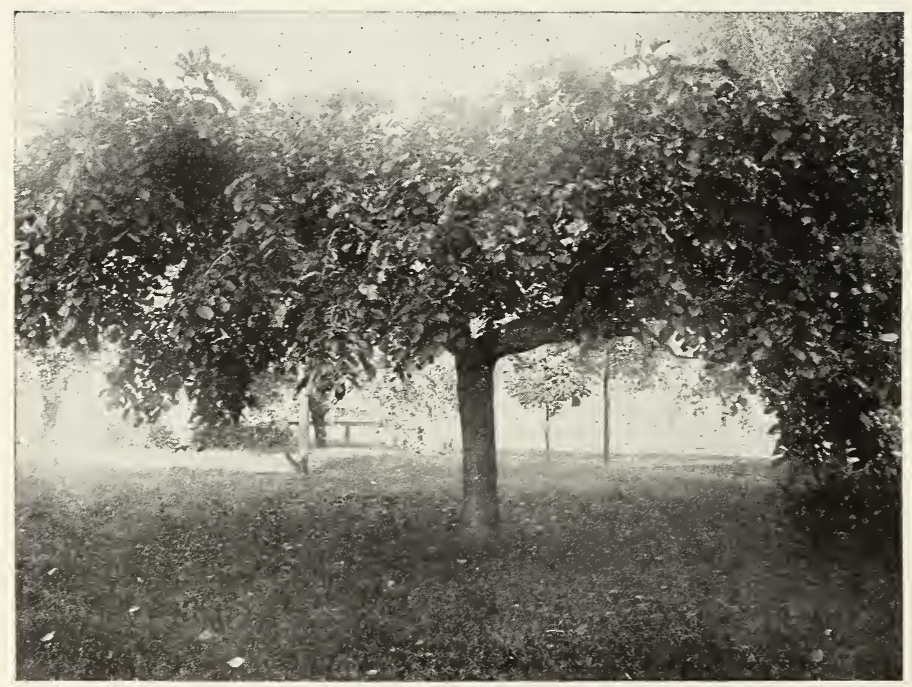

Camperdown Weeping Elm

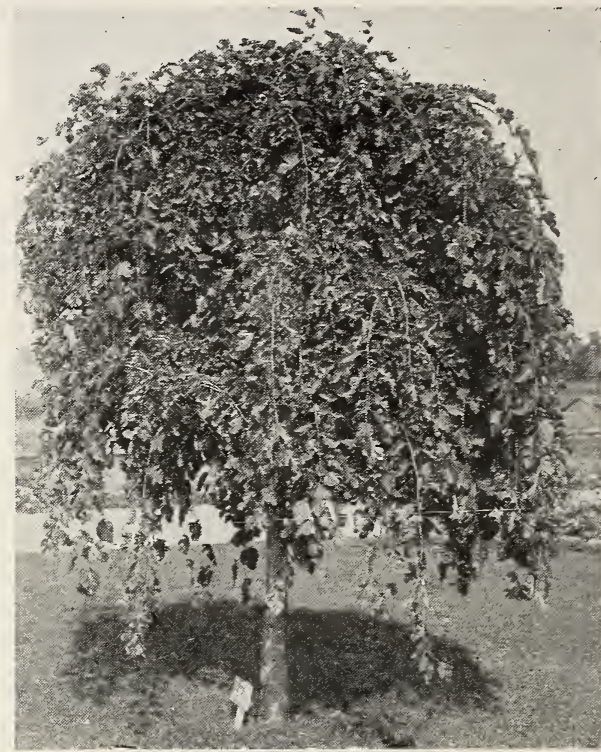

Tea's Weeping Mulberry

Kilmarnock Weeping Willow (S. Caprea, var. pendula). A distinct variety having reddish shoots and large glossy foliage; grafted about five feet from the ground it makes a very desirable small lawn tree, with the branches drooping gracefully to the ground; well suited to planting in cemetery lots or small enclosures; hardy and of vigorous growth.

Niobe Weeping Willow. Imported by Prof. $\mathrm{N}$. E. Hansen, who gave it the name. It is a golden barked willow of a decided weeping habit. It is extremely hardy and for this reason will, we think, be of especial value to the Northwest, where we are badly in need of a strictly hardy weeping willow. We offer it this season for the third time, and have great hopes for it.

Thurlow Weeping Willow. This willow, like the Babylonica, is not grafted or budded; its nature is weeping. Tree vigorous, fast grower, very hardy, and a graceful weeper. The branches are very slender, leaves long, of bright green, with a lighter shade of green on the lower side.

Wisconsin Weeping Willow (S. Babylonica, var. dolorosa). Of drooping habit and considered the hardiest. Valuable on account of its ability to resist severe cold.

Furnish shade and orramentation to your lawn or parkway by planting healthy trees. The grown-ups will admire them, the children will bless you for your thoughtfulness. 


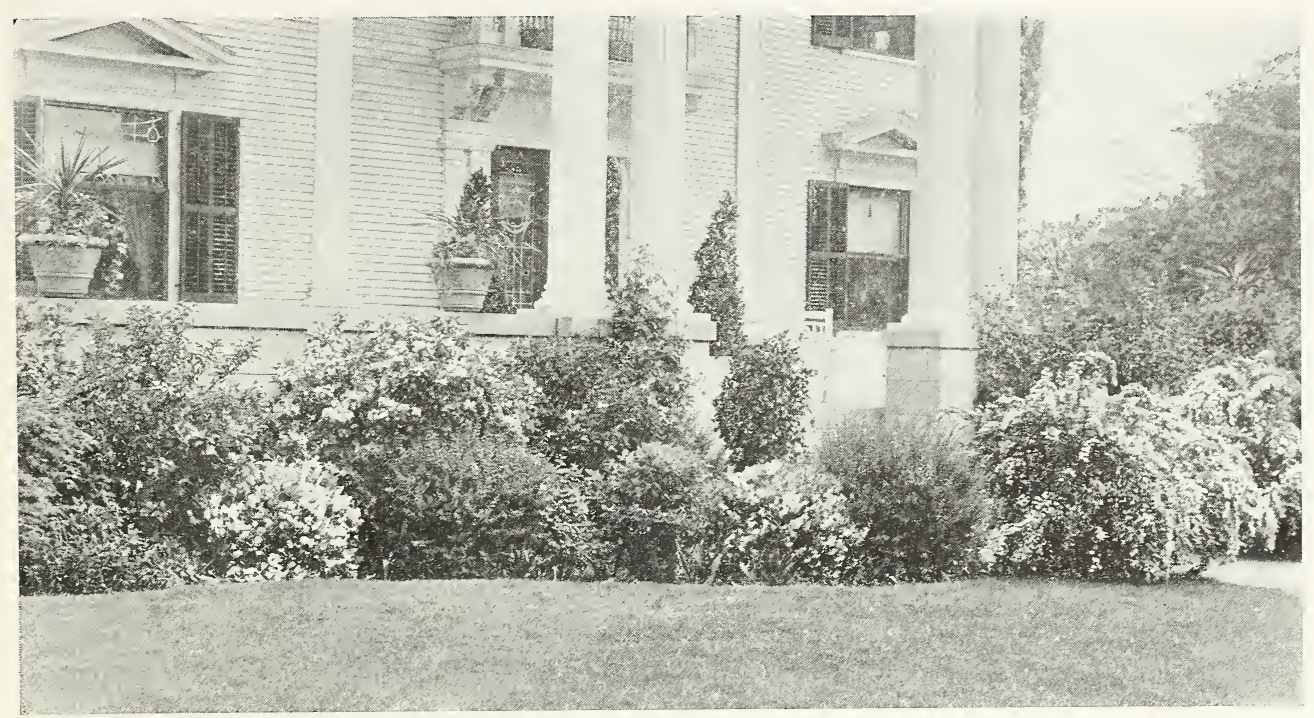

\section{Ornamental Shrubs}

\section{APPROXIMATE HEIGHT OF A FEW PROMINENT SHRUBS}

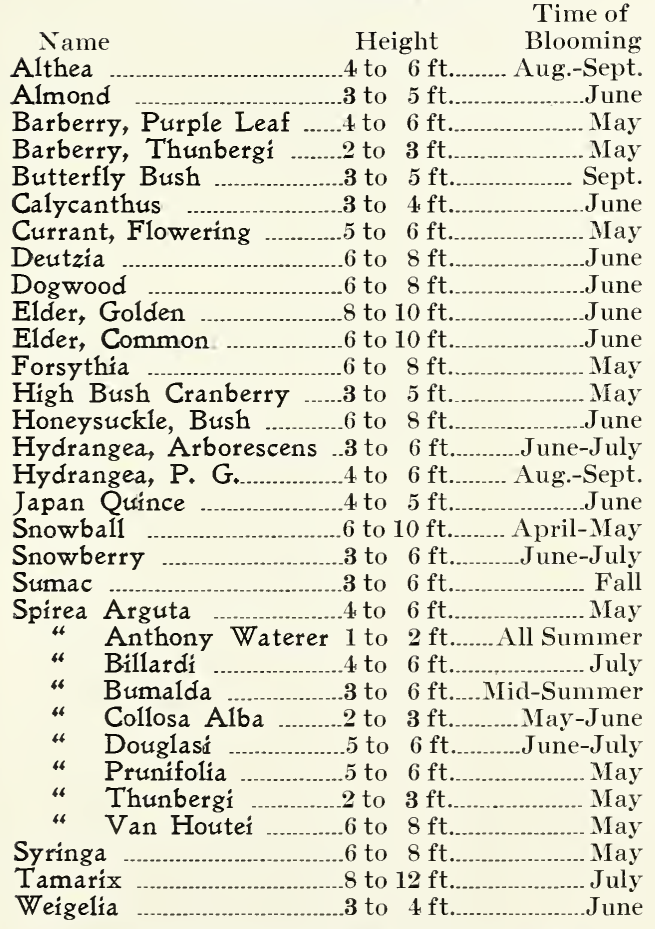

\section{SHRUBS FOR SHADY LOCATIONS}

Siberian Dogwood Forsythia

Amoor River Privet

Viburnum Dentatum
Deutzia, Lemoinei Hydrangea Arborescens Sumac Barberry Thunbergi

\section{ACACIA. Robinia}

Flowering Locust

Rose Acacia (R. Hispida). A native species of spreading irregular habit; long clusters of peashaped, rose-colored flowers in June and at intervals through the season. Foliage a light green.

Rose Acacia (R. Neo-Mexicana). Grows five to six feet high; branches covered with stiff prickles; flowers rose color in drooping racemes.

\section{ALTHEA. Hibiscus Syriacus}

Rose of Sharon. One of the most showy and beautiful of shrubs; flowers large, double and many brilliant colors; blooms freely in August and September, when few other trees and shrubs are in blossom.

Ardens. Violet color; petals quilled; very large and double.

Boule de Feu. Violet red color; very double; blooms late.

Coelestis. Single; flowers blue.

Duchess de Brabant. Reddish-lilac color, very large and double.

Elegantissima. Double white.

Rubra Flore Pleno. Double red.

Jean de Arc. One of the best; pure white and double.

Lady Stanley. Very double; white, with beautiful blush.

Pulcherima. Large, double, rosy-white.

Totus Albus. Single, pure white, very fine.

Variegated Leaved. Foliage finely marked with light yellow; flowers purple and double. 


\section{ALMOND. Amygdalus}

Pink Double-Flowered Almond (A. flore pleno Rosea). A vigorous, beautiful tree, covered in May with rose-colored blossoms like small roses; hardy.

White Double-Flowered Almond (A. flore pleno Alba). Same as above except blossoms are pure and white.

\section{BARBERRY, Berberis}

Canadian Barberry (B. Canadensis). A native variety of shrub or small tree with handsome foliage, and yellow flowers in May, succeeded by bright colored fruit; very ornamental in the fall and winter.

European Barberry (B. Vulgaris). A handsome shrub with yellow flowers in May or June; followed with orange-scarlet fruit.

Japanese Barberry (B. Thunbergii). From Japan; of dwarf habit, small foliage, changing to a beautiful coppery red in the fall. Is very ornamental when used as a hedge.

Purple-Leaved Barberry (B. Vulgaris, var. purpurea). Grows three to five feet high; foliage and fruit violet purple; very effective in groups or masses; yellow blossoms.

\section{BUCKTHORN, Rhamnus}

R. Cartharticus. A very fine vigorous, hardy shrub of European origin with dark green foliage, white flowers and small black fruit. A popular hedge plant.

\section{THE BUTTERFLY BUSH}

\section{Buddleia Variabilis Magnifica}

It is doubtful whether any new shrub ever distributed in this country offered so much to all classes of garden makers as Buddleia variabilis. It is coming to be generally known as the Butterfly Bush, because of the remarkable attraction which

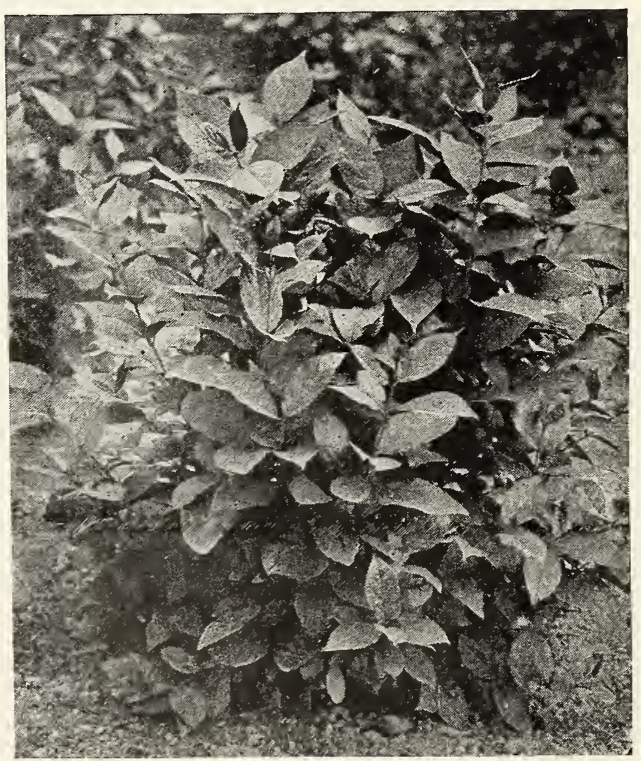

Calycanthus

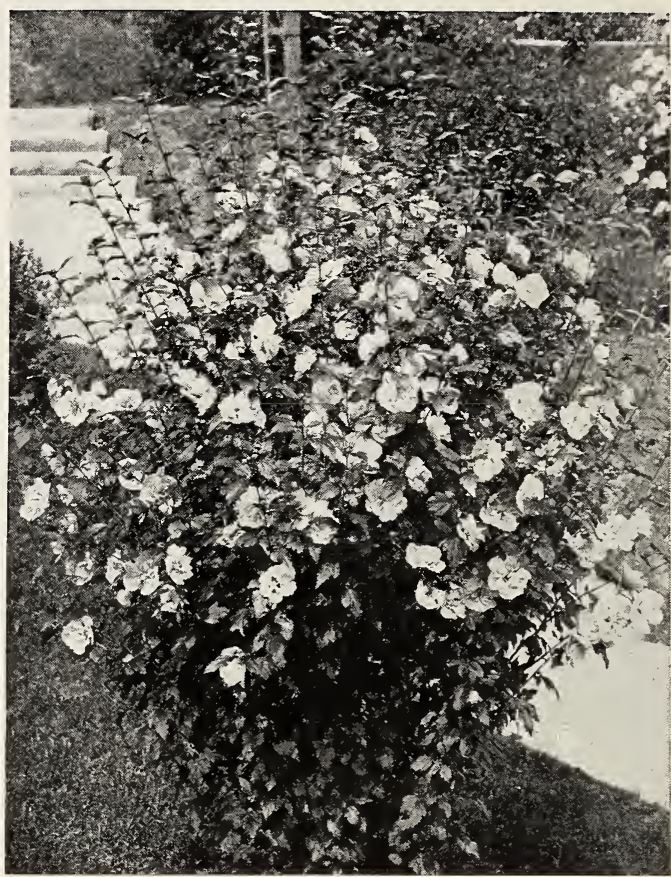

Althea

it has for butterflies of all kinds and colors. It is very hardy and extremely easy to grow, but if set out the last of April or the first of May it will be blooming early in August of the same year, even in New England, and it will not cease to bloom until cut down by the frost. Even then it seems to succumb only under protest, starting up again if there is a week of warm weather.

The plant was discovered in the wilds of Western China, but it thrives in the soil and climate of the United States. Sometimes it is called the "summer lilac," for the flowers somewhat resemble those of the lilac in form. They are borne closely on long spikes or stems and are mostly a light heliotrope in color.

With Constant Cutting it Blooms a Whole Season

Every branch bears a flower spike, and if the blossoms are cut constantly with as long stems as possible, new branches will continue to appear, with new spikes of bloom, as long as the season lasts. Then, if the whole plant is cut down to within eight or ten inches of the ground in the spring, a host of new branches will grow in a very short time and there will be a wealth of flowersand of butterflies. Quite apart from its own merits as a flowering shrub, buddleia is worth growing for the great numbers of these beautiful creatures that it woos to the garden. Sometimes scores may be counted on a single bush at one time.

In spite of their rather peculiar shape the flowers of the Butterfly Bush lend themselves well to house decoration. They keep several days in water if they are put in a fairly cool place and not crowded in a vase. A very faint and delicate odor is exhaled by the flowers, an odor that to some people resembles that of heliotrope.

Though buddleias are an attractive addition to the border planting, they are most effective when 
massed in beds. They grow from four to six feet high, like sun for at least half the day and need an abundance of water if they are to give best results.

Flowering as freely as they do, too, they prefer rather rich soil. In the Northern States it is a wise precaution to heap up soil around the lower part of the plants in the fall, in the same manner that roses are protected from the severity of winter cold. It does not matter if the tops are killed back, as they are to be cut away in any event to give the plant a whole new start in spring.

\section{CALYCANTHUS. Sweet Scented Shrub}

C. Floridus. A native species with double purple flowers, very fragrant, and the wood is also fragrant; foliage rich dark green; blooms in June and at intervals afterward.

\section{CARAGANA, Siberian Pea}

Siberian Pea Tree (C. Arborescens). A shrub or low tree with pea-shaped yellow flowers; hardy and useful for massing.

\section{CEPHALANTHUS}

Button Bush (C. Occidentalis). A tall-growing native shrub with globe-shaped heads of white flowers in July.

\section{COLUTEA}

Bladder Senna (C. Arborescens). A large shrub with small, delicate foliage, and yellow pea blossom shaped flowers in June, followed by reddish pods.

\section{CURRANT. Ribes}

Crimson-Flowered Currant (R. Sanguineum). A native variety with deep red flowers, blooms early in the spring.

Crandall's. A seedling from the West; blooms profusely; bright yellow flowers. Fruit of a red black color.

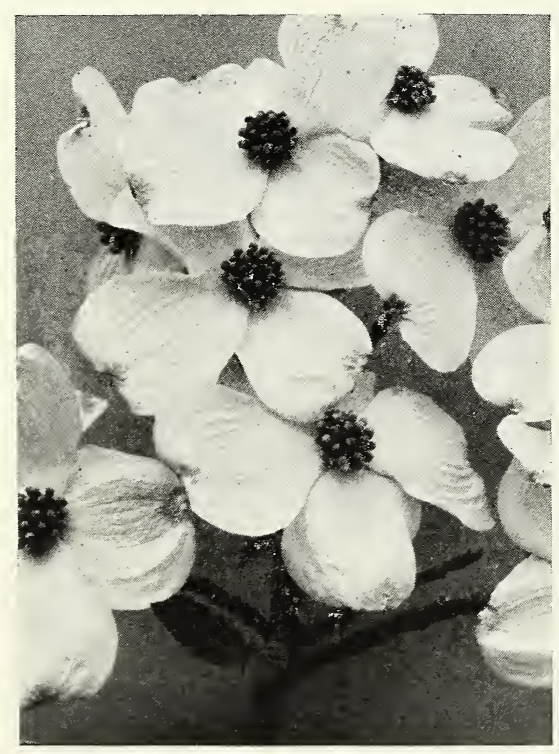

Flowering Dogwood

Sweet Pea Shrub (D. Penduleflorum). A low-growing shrub having rose-purple, pea-shaped blossoms in great profusion; blooms in September and continues until late October; tops die down after frost, but come up again in the spring. A valuable shrub for massing or borders.

Gordon's Flowering Currant (R. Gordonianium). Very hardy and profuse blooming; flowers are beautiful crimson and yellow in pendant bunches; blooms in May.

Yellow-Flowered Currant (R. Aureum). A native species with beautiful shining foliage and yellow flowers.

\section{DESMODIUM}

DEUTZIA
Golden-Leaved Deutzia (D. Gracilis, var. aurea). Foliage a beautiful yellow; flowers white and more showy than the slender branches.

Double-Flowered Deutzia (D. Crenata flore pleno). A very hardy shrub with luxuriant foliage and a profusion of double white flowers tinged with rose, produced in late June on long racemes; one of the most desirable in cultivation.

Lemoine (D. Lemoinei). Flowers pure white; shrub dwarf and free flowering; excellent for forcing.

Pride of Rochester. Produces large double white flowers, tinged with rose; vigorous grower, profuse bloomer and one of the earliest to bloom.

Slender Branched Deutzia (D. Gracilis). Of dwarf habit; flowers pure white; one of the first to bloom. Fine for pot culture and winter blooming.

\section{DOGWOOD. Cornus}

European Red Dogwood (C. Sanguinea). A valuable shrub for grouping and massing; very ornamental in winter when the bark is blood-red; foliage variegated in summer. 
Red-Flowered Dogwood. A variety producing flowers suffused with bright red; blooms when young. One of the finest flowering trees.

Red Osier Dogwood (S. Stolonifera). Produces white flowers in early June; in winter young shoots are a blood-red color.

C. Stolonifera var. Flaviramea (Yellow Branched Dogwood). A rery pretty shrub for winter color effect, bark bright yellow.

Síberian Dogwood. Free growing, 6 to 10 feet tall, and very hardy; forms a small, handsome tree in some situations; its clusters of small white flowers in early summer are very dainty, and its bark is a showy, dark red in winter. All the Siberian Dogwoods bear in early fall a profusion of whitishblue berries, making them distinctly ornamental after the flowers have gone.

Variegated-Leaved Dogwood (C. Elegantissima Variegata). Foliage a pale yellow, turning to a rose color in the fall; branches blood-red.

\section{ELEAGNUS}

Japanese Silver Thorn (E. Longipes). A shrub about six feet high; flowers yellowish-white and fragrant; fruit very ornamental with an agreeable slightly acid flavor; one of the most desirable for lawns.

\section{ELDER, Sambucus}

Common Elder (S. Canadensis). A large showy shrub, very ornamental in foliage; fruit and flowers and blossoming in June; flowers white, borne in large panicles; fruit reddish-purple berries in the fall.

Cut-Leaved Elder (S. Nigra, var. Laciniata). One of the best cut-leaved shrubs; a valuable va-

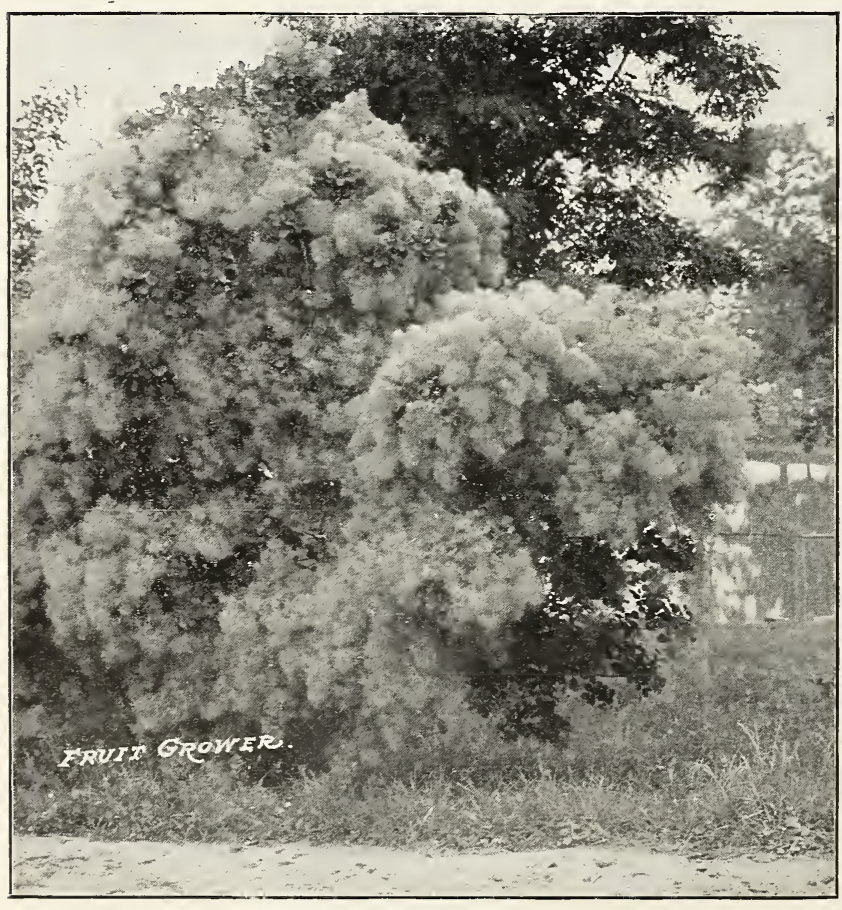

Fringe or Smoke Tree

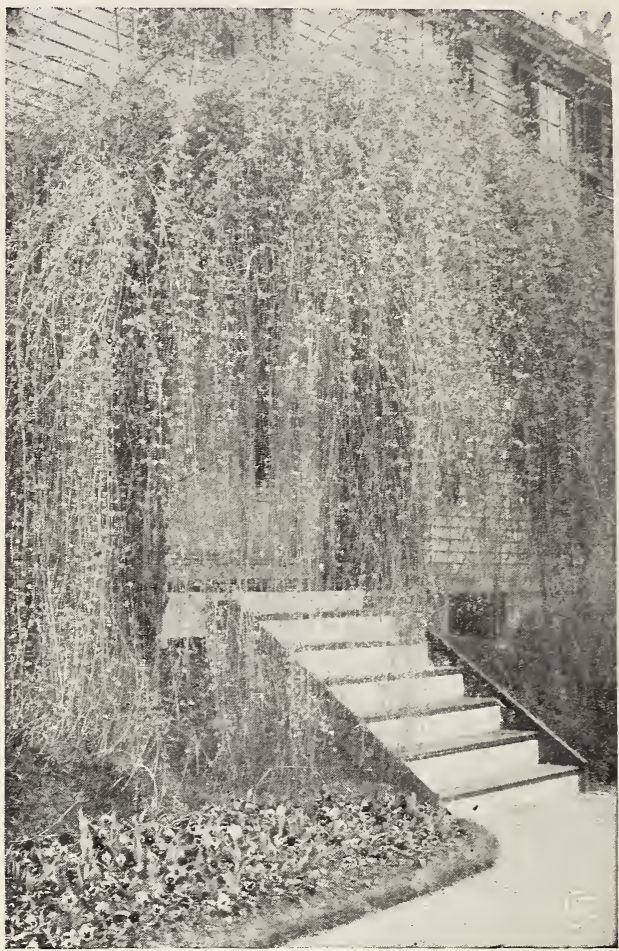

Forsythia (Golden Bell)

riety with elegantly divided leaves.

Red-Fruited Elder (S. Racemosa). Of somewhat stockier growth than the other varieties, with white flowers in cymes, followed by red fruits. Blooms in early summer.

Golden Elder (S. Nigra, var. aurea). A handsome variety with golden-yellow foliage.

Variegated-Leaved Elder (S. Nigra, var. variegata). The foliage is mottled with yellow and white; one of the best variegated leaved.

\section{EUONYMUS. Strawberry Tree}

American Burning Bush (E. Americanus). Very conspicuous in the autumn and winter, when loaded with scarlet seed pods, from which the orange colored berries hang on slender threads.

European Burning Bush (E. Europeanus). From Europe, and a favorite in old gardens, of good size, with rosy red pods.

\section{EXOCHORDA. Pearl Bush}

Pearl Bush (F. Grandiflora). A fine shrub, producing large white flowers in May; one of the finest in its season. 


\section{FORSYTHIA. Golden Bell}

Fortune's Forsythia (F. Fortuneii). A beautiful shrub of medium size; flowers are a bright yellow and appear before the leaves; foliage deep green; the best of the early flowering shrubs.

F. Intermedia. Flowers bright golden-yellow; foliage glossy green; resembles the Viridissima, but hardier. A valuable variety.

F. Viridissima. A fine hardy variety; leaves and bark deep green; flowers deep yellow, an early bloomer.

Weeping Forsythia (F. Suspensa). Resembles the Fortune in its flowers, but the growth is somewhat drooping.

\section{FRINGE or SMOKE TREE. Rhus}

Purple Fringe (R. Cotinus). A valuable ornamental shrub with curious fringe or hair-like flowers that cover the whole tree, giving the appearance of mist or smoke; wide, spreading habit, which requires some room to grow to the best advantage.

White Fringe or Chionanthus (C. Virginica). A very ornamental shrub of easy cultivation, dark green foliage, flowers pure white, having narrow fringe-like petals; blooms in May and June.

\section{HALESIA. Silver Bell}

Silver Bell Tree (H. Tetraptera). A beautiful large shrub forming a low, wide head, profusely covered with a mass of small snowy white flowers: blooms about the middle of May; foliage dark green. A valuable acquisition to any lawn.

\section{HONEYSUCKLE BUSH. Lonicera}

Fragrant Bush Honeysuckle (L. Fragrantissima). A spreading shrub with deep green foliage and fragrant small flowers which appear before the leaves; bushes are erect in growth.

Pink Tartarian Honeysuckle (L. Tartarica rosea). Pink flowers that make a lovely contrast with the foliage; planted with the Grandiflora, the two make a beautiful display.

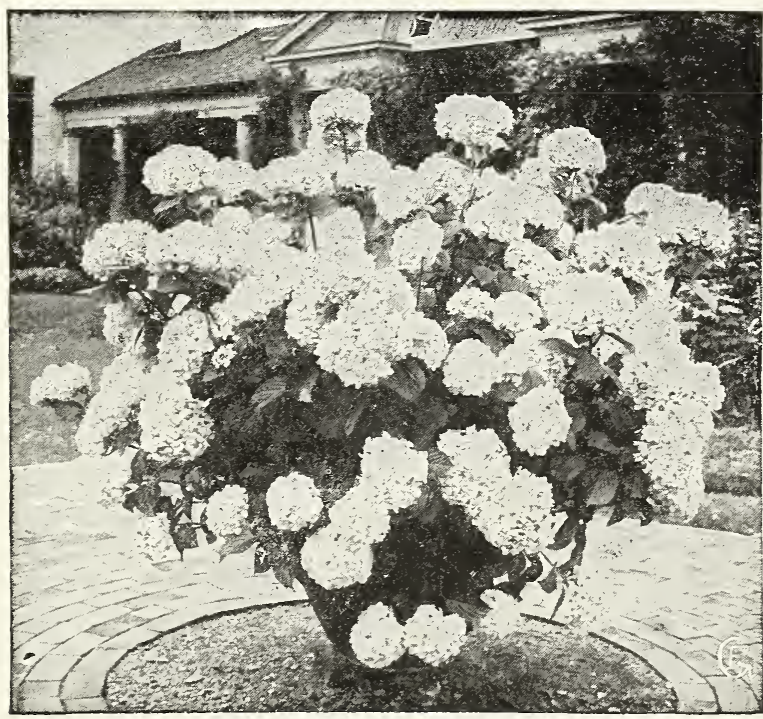

Hydrangea
Pink-Flowered Honeysuckle (L. T. var, grandiflora). Produces large, bright red flowers striped with white; blooms in June.

Red Tartarian Honeysuckle (L. T. var. rubra). Blooms early in the spring; flowers a beautiful bright red.

White Tartarian Honeysuckle (L. T. var. Alba). Produces creamy-white, fragrant flowers in May and June; forms a high bush.

\section{HYDRANGEA}

Hardy Hydrangea (H. Paniculata grandiflora). A beautiful, tall shrub with leaves of bright, shiny green; flowers borne in huge panicles from 8 to 12 inches long, light pink, changing to brown later in the fall; blooms in August and September; can be grown in tree form successfully and makes a very desirable lawn ornament.

Japanese or Garden Hydrangea ( $\mathrm{H}$. Hortensis, var. Thos. Hogg). One of the hardiest; well adapted to pot culture and outdoor cultivation; flowers pure white. A profuse bloomer.

White-Flowered Hydrangea ( $H$. Arborescens Alba Grandiflora). Resembles the Paniculata in general form and shape of flowers; borne in panicles of pyramidal shape from 5 to 8 inches in diameter and 8 to 10 inches long; changing to a greenish-white. One of the best.

Hydrangea Arborescens. June and July. A bushy plant from our native woods, with corymbs of white flowers in June and July. It is the most hardy of Hydrangeas, and particularly desirable for planting in shady places.

\section{JAPAN QUINCE. Cydonia}

Scarlet Japan Quince (C. Japonica). One of the best flowering shrubs; flowers a bright scarlet crimson, borne in great profusion in early spring; foliage retains its color of bright glossy green the entire summer; hardy; make good hedge plants.

\section{KERRIA. Corchorus}

Globe Flower (C. Japonica). A slender green branched shrub, 5 to 6 feet high, with globe-shaped yellow flowers from July to October. Very ornamental.

\section{LILAC. Syringa}

Lilacs are well known, beautiful shrubs, indispensable in every collection. They can be moved with every success in the fall, but water must be used generously.

Alphonse Lavalle. Very large trusses of double blue flowers with violet shading. A desirable, dependable free bloomer.

Charles the Tenth. Large, long trusses of single, reddish-purple flowers.

Charles Jolly. Double, blood red. Buds opening a dark reddish-purple. Strikingly beautiful and extra choice.

Chinese Tree Lilac. The genuine in both this and Japan Tree Lilac are scarce. Many of the bush forms are trimmed high and offered as trees. The true Chinese grows about 20 feet high, resembling the cherry tree in shape, with the trunk light green in color. Trees 4 inches through at the base were literally covered with snowy white flowers in early July this year. Fast growing and excites the greatest comment wherever seen. Hard 
to keep them on hand until they make much growth, as the demand keeps them always cleaned up.

Dr. Bretschneider. Large, coarse leaves. Great masses of flowers nearly white. A prolific bloomer. Comes into flower about the 10th of June. We consider this the most desirable of the late bloomers. Blooms while exceedingly young. Bushes, this year, 24 inches high, carried as high as 50 open bunches at one time.

Emile Lemoine. Large trusses of double flowers, rosy lilac. Favorite of all doubles.

Grandiflora Alba. A good white variety.

Japan Tree Lílac. Matures into taller trees than the Chinese. Darker in bark and color, but habits much the same. Immense spikes of grayish blossoms. Both varieties are extremely hardy, lacking the natural enemy of the lilac.

Jean Bart. Fine clusters of double rosy carmine. Free bloomer.

Madame Casimir Perier. Very large, double, creamy-white trusses, very beautiful. Free blooming, commencing while rery young.

Mme. Abel Chatenay. Pure white flower in very large panicles.

Persian Purple. A small-leaved variety, in habits and shape much like the Rouen. Bloom forms at end of branch. Laterals from this branch blooming join in making one large cluster sometimes over 12 inches in length.

Persian White. Delicate white, fragrant flowers, shaded with purple.

President Grevy. Double, light purple, bunches very compact.

Pyramidalis, A beauty. Light soft lavender flowers, usually in double clusters.

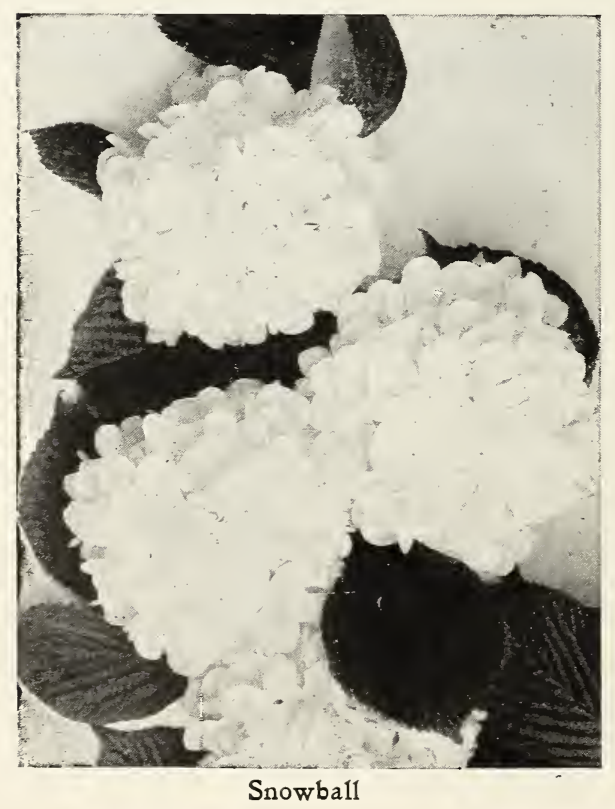

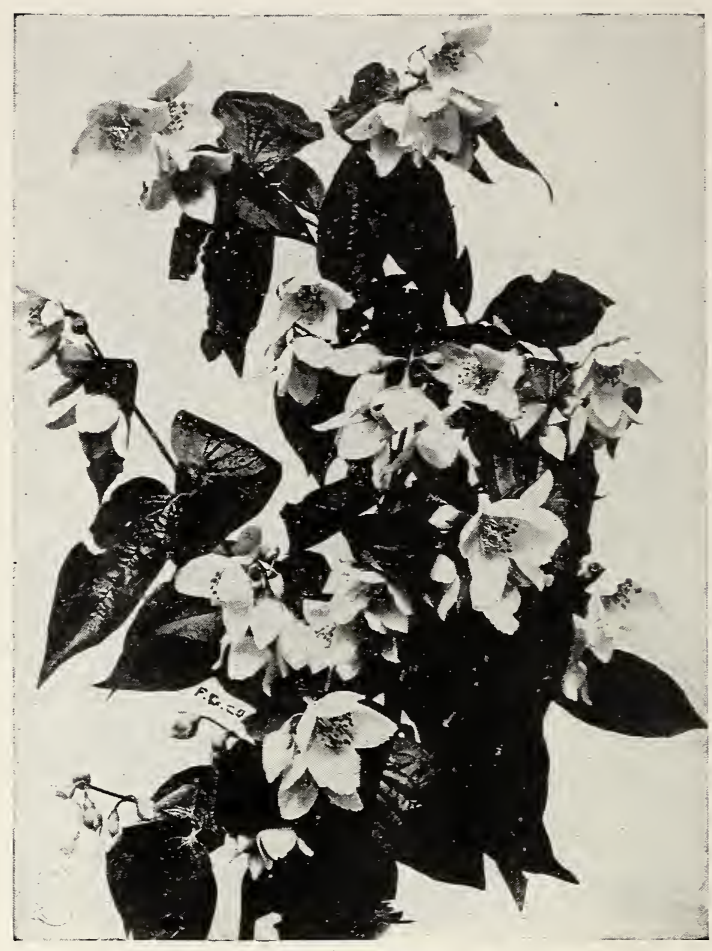

Philadelphus

Rouen. A cross between the old common purple and the Persian. Color reddish purple. Prolific bloomer and valuable for hedge purposes. Does not sucker like the common sorts, but stools heavily. Grows about 8 feet high and forms a windbreak, dividing line or screen.

Senator Volland. Dense compact blooms of brilliant rosy-red. A very free bloomer.

Siberian White. Pinkish white blossoms. Very hardy and desirable.

Teas' Mammoth. Single reddish-purple flowers. An imported variety.

Villosa. A stout, bushy shrub. Rich, bright green foliage. Buds light purple, opens light purple bordering on white. Very rare and desirable. June bloomer.

\section{SINGLE LILACS}

Charles $\mathrm{X}$. A strong rapid-growing variety, large shining leaves; flowers reddish-purple.

Marie Le Graye. Large panicles of white flowers; the finest white lilac.

Rubra de Marlay. Flowers very dark lilac.

Souvenir de Ludwig Spaeth. Flowers a dark purple borne in large panicles. The best of the dark varieties.

\section{MAHONIA. Ashberry}

Holly-Leaved Mahonia (M. Aquifolium). A native shrub, very handsome, with purplish shining prickly leaves and bright yellow flowers in May, followed by bluish berries; very ornamental. 


\section{PRIVET. Ligustrum}

Amoor River Privet (L. Amurense). A valuable ornamental shrub for hedges and borders; very hardy; foliage glossy green and holds its color almost the entire year; will stand shearing to any extent.

California Privet (L. Ovalifolium). The wellknown variety; vigorous and hardy; deep glossy green; useful for hedges and borders.

Chinese Privet (L. Ibota). A native of China and Japan; foliage long and shining; flowers large, white and fragrant; a distinct sort, valuable for its flowers and foliage.

Polish. Especially valued on account of its hardiness. Leaves similar to those of the California, remaining green very late in the season.

Regel's Privet (L. Regelianum). A dense low shrub with spreading branches, pendent at the end; a very graceful bush for hedges; needs very little trimming.

\section{RHODOTYPOS. White Kerria}

R. Kerrioides, A choice and rare Japanese shrub, recently introduced. It is a slender branched bush, with very pretty, deeply veined leaves, and pure white flowers, borne at intervals all summer.

\section{SNOWBALL. Viburnum}

Common Snowball (V. Opulus Sterilis). Grows 6 to 8 feet high, the old-fashioned snowball; its large globular clusters of pure white flowers are produced in May and June and make a very attractive appearance.

High Bush Cranberry (V. Opulus). It has handsome broad foliage of a shining dark green color, changing to rich coppery tints; flowers are white and very conspicuous; the fruit is a brilliant scarlet and hangs in long pendent clusters nearly all winter. A very desirable ornament to any lawn.

\section{Lantana, Wayfaring} Tree. A rugged treeshaped shrub, covered with dense, rich foliage, wrinkled $\mathrm{like}$ s ag e. Flowers are borne in flat clusters, followed by large red fruit, turning to black later. In early winter when other shrubs are bare the foliage of the Lantana is still green and cheerful.

\section{SNOWBERRY}

\section{Symphoricarpus}

Coral Berry (S. Vulgaris). A slender branched $\mathrm{upright}$ shrub, valuable for planting in $\mathrm{s} \mathrm{hady}$ places, as the foliage is very persistent; the fruit is a purplish red and hangs on well into winter; flowers small and rose colored.

Snowberry (S. Racemosus). Same as the above except the berries are a pure snow white; flowers rose colored, but larger.

\section{SUMACH, Rhus}

Cut-Leaved Staghorn Sumach (R. Typhina laciniata). A showy, broad-headed shrub with large, long, deeply cut foliage, light green in color, changing to shades of red and yellow in the fall; the new growth is clothed with a peculiar down, giving an appearance of the growing horn of a deer; the bark below is a rich orange color.

Cut-Leaved Sumach (R. Glabra, var. laciniata). A variety of the smooth Sumach with deeply-cut fern-like foliage.

Smooth Sumach (R. Glabra). A shrub 8 feet high, with handsome green foliage, changing to beautiful autumn tints; showy spike of crimson fruit.

\section{SPIREA. Meadow Sweet}

S. Arguta. Of dwarf habit, spreading head; flowers clear white; the best of the very early flowering white varieties; blooms in May.

Ash Leaved (S. Sorbifolia). A vigorous grower with foliage similar to the Mountain Ash and long spikes of beautiful white flowers; blooms in July.

Billard's Spirea (S. Billardi). Flowers are rose colored.

Bridal Wreath (S. Prunifolia flore pleno). Foliage a dark shining green, changing to autumn tints in the fall; flowers double, pure white and are borne the entire length of the twigs; one of the most popular varieties.

S. Bumalda. A handsome variety from Japan; dwarf habit and vigorous growth; foliage narrow; flowers rose colored and borne in great profusion; blooms a long time.

Anthony Waterer. A fine dwarf Spirea with dark crimson flowers. Blooms nearly all summer.

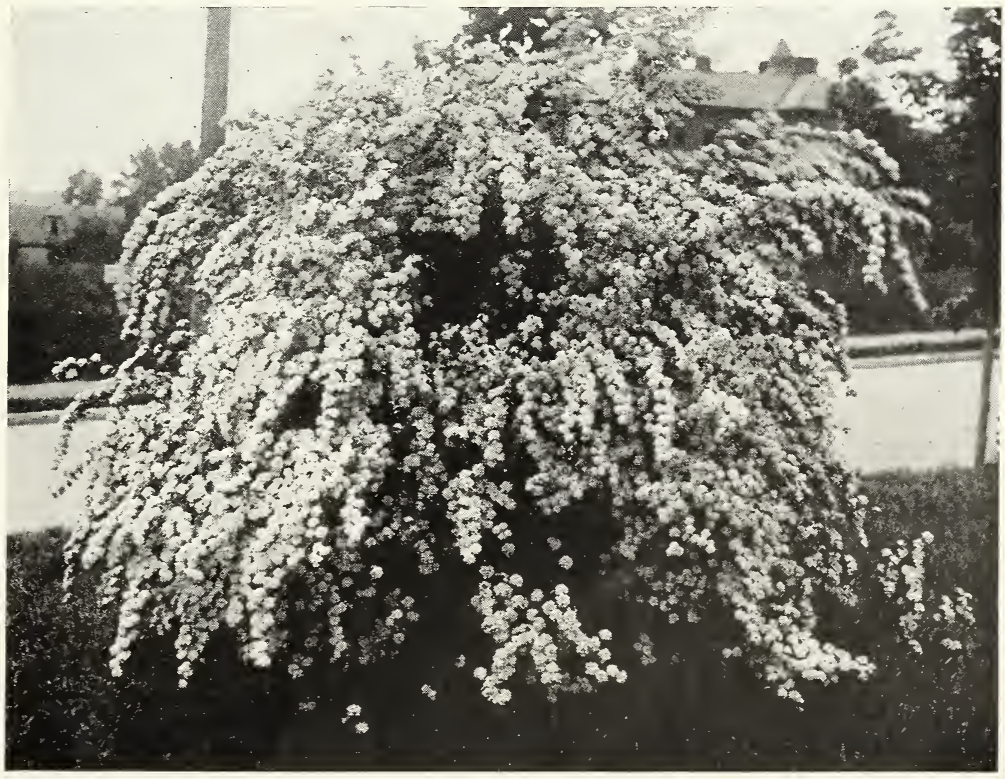

Van Houttei Spirea 
Douglas' Spirea (S. Douglasi). A beautiful rariety with spikes of deep rose colored flowers in July and August.

Fortune's Dwarf White Spirea (S. callosa alba). A white flowering rariety of dwarf, symmetrical form; keeps in flower all summer. A valuable sort.

Golden-Leaved Nine Bark (S. Opulifolia, var. aurea). A beautiful variety with golden-yellow foliage and double white flowers in June.

Nine Bark (S. Opulifolia). One of the most vigorous growers; foliage light green; flowers white and produced in great profusion.

Thunberg's Spirea (S. Thunbergii). Dwarf habit and rounded graceful form; branches slender and drooping; flowers pure white and borne the entire length of the twigs; foliage nar-

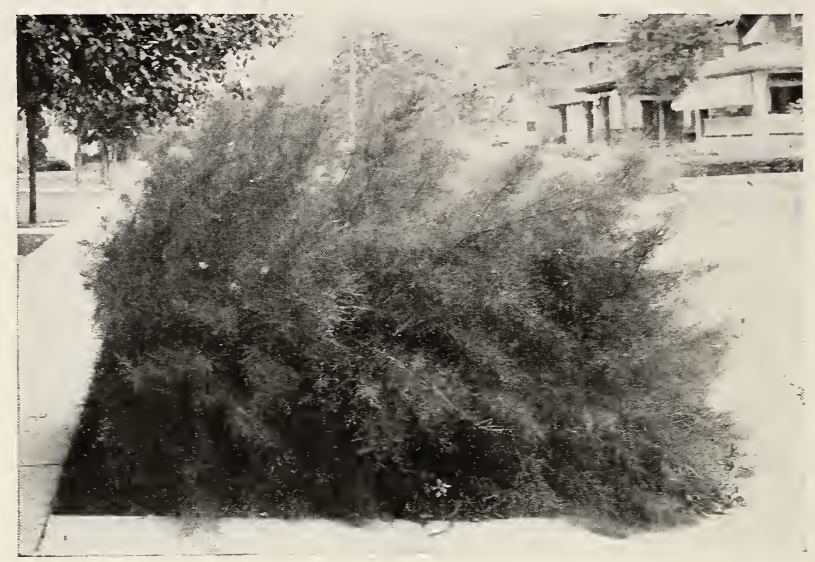

\section{Tamarix} row and long, turning to orange scarlet in the fall.

Van Houttei Spirea (S. Van Houttei). This is undoubtedly the most popular of all the rarieties; foliage a rich green, changing to beautiful tints in the fall; in blooming season the bush is a perfect mass of pure white flowers, the branches bending to the ground; indispensable ornament for lawns and hedges.

\section{SYRINGA or MOCK ORANGE Philadelphus}

Garland Syringa (P. Coronarius). A well-known shrub, pure white, fragrant; first bloom.

Golden-Leaved Syringa (P. Coronarius, var. Aurus). A handsome variety with golden-yellow

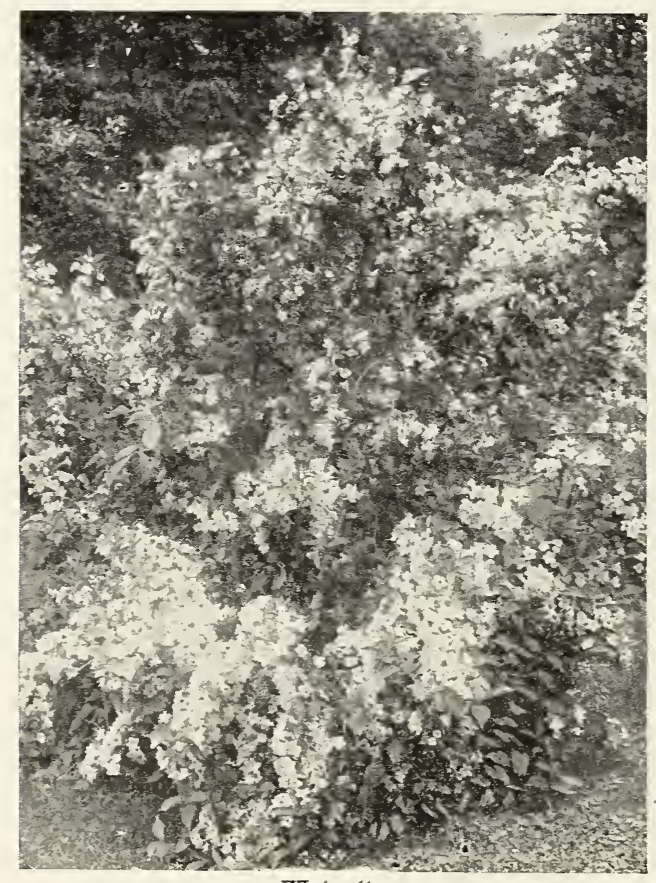

Weigelia

foliage; keeps its color the entire season. Is splendid for grouping with other rarieties for pleasing effects.

Gordon's Syringa (P. Gordononianus). A rigorous grower and profuse bloomer; flowers white, fragrant and a late bloomer.

Large-Flowered Syringa (P. Grandiflorus). Has very large, showy flowers, somewhat fragrant; bark reddish; a rapid grower.

Lemoine's Syringa (P. Lemoinei). A graceful shrub with very rich foliage and large, pure white flowers in June.

\section{TAMARIX}

T. Amurensis. Growth is slender and graceful, with silvery foliage; pink flowers borne on short spikes on the young growth only.

\section{WEIGELIA. Diervilla}

The Weigelias are shrubs of erect habit while young, but gradually spread and droop as they acquire age; flowers are large, trumpet-shaped, of all shades and colors; rery effective for grouping and borders; blossoms are produced in June and July.

D. Candida. Flowers pure white, produced in June and continue to bloom nearly all summer.

D. Eva Rathke. Flowers a brilliant crimson; a beautiful, clear, distinct shade.

D. Floribunda. A fine variety, flowers a dark red and a profuse bloomer.

D. Rosea. An elegant rariety with fine rose colored flowers appearing in June.

D. Nana Variegata. Of dwarf habit and clearly defined silvery-rariegated leaves; flowers rose colored.

D. Van Houttei. Flowers are a rich shade of carmine and are produced profusely.

Abel Carriere. Of all the hybrid Weigelias this is one of the finest, growing to be a tall shrub in time. It blooms during May and June with great quantities of rose-carmine flowers with a yellow spot in the throat. 


\section{Hardy Vines}

\section{AKEBIA}

Akebia Quinata. Japanese variety of climbing shrub with large leaves and white, purple-centered flowers.

\section{ARISTOLOCHIO, Dutchman's Pipe}

A. Sipho. A fine, hardy climber and well known in some.parts of the country as Chinese Yam. The tubers grow very large and are edible, like sweet potatoes. The vine is a beautiful, rapid grower, producing sweet-scented flowers.

\section{AMPELOPSIS}

American Ivy or Virginia Creeper (A quinquefolia). One of the finest vines for covering walls, verandas or trunks of trees; foliage green, turning to a rich crimson in autumn; a rapid grower and quickly fastens to anything it touches.

Boston Ivy (Veitchii). Leaves smaller than the American; forms a dense sheet of green as leaves overlap each other; it is a little difficult to start, but when once established requires no further care; foliage changes to a crimson scarlet in the fall; very valuable for covering brick and stone structures, rockeries, walls, etc.

Engelman's Ivy or Woodbine (A. quinquefolia, var. Englemanni). A type of quinquefolia which has long been desired. It has shorter joints and smaller and thicker foliage. It is better equipped with tendrils, by which it will climb walls of stone or brick as closely as the Veitchii (Boston Ivy). It should be planted in the Central and Northwestern States, in place of the Veitchii, as it is perfectly hardy, withstanding heat and cold better.

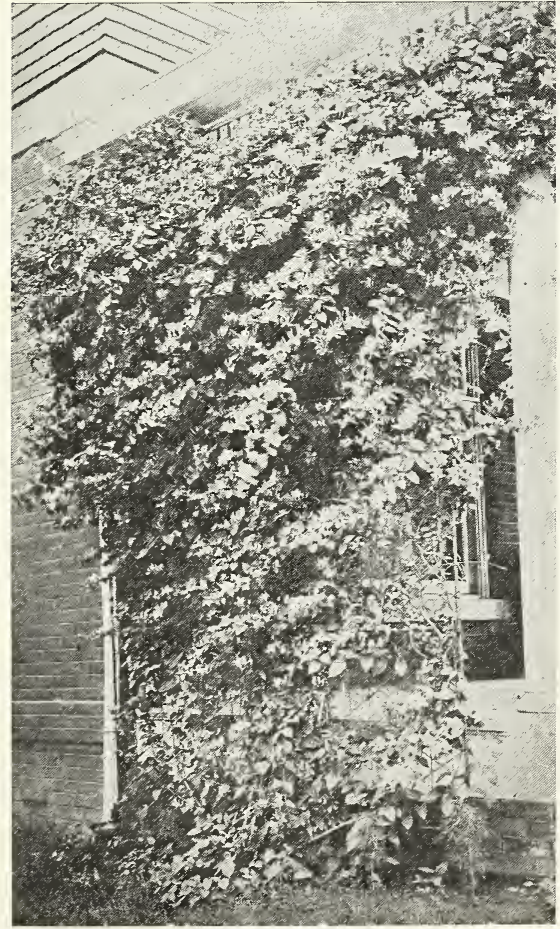

Honeysuckle

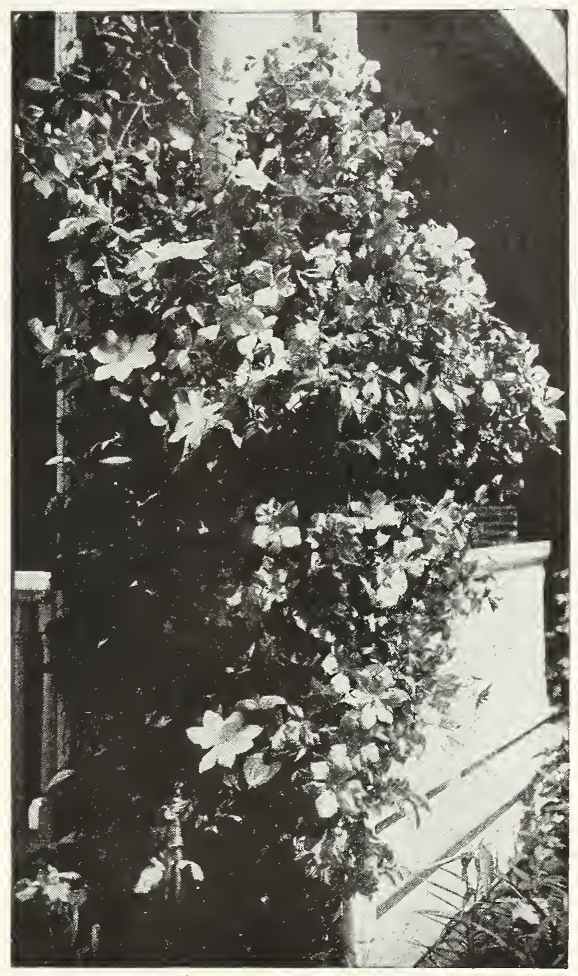

Clematis Jackmanni

\section{BIGNONIA. Tecoma}

Trumpet Creeper (B. Radicans). A hardy climbing plant with large trumpet-shaped scarlet flowers appearing in August.

Large Flowered Trumpet Creeper (B. Radicans, var. Grandiflora). A beautiful variety with very large flowers, salmon colored, yellow center and striped with red.

\section{CELASTRUS, Bitter Sweet}

Climbing Bitter Sweet (C. Scandens). A native climber with fine large leaves, yellow flowers and clusters of capsuled orange fruit; a rapid grower.

\section{CINNAMON VINE. Díscorea}

Chinese Cinnamon Vine (D. Batatas). A beautiful, hardy, very fragrant, immensely rapid growing vine; requires no attention and will continue to grow for years.

\section{CLEMATIS. Virgin's Bower}

A beautiful class of hardy climbers, many of the varieties have flowers 5 to 6 inches in diameter. They are very valuable for training around and over pillars, verandas, fences, rock work, etc.

\section{Large Flowering Varieties}

Duchess of Edinburg. Fine, large, double white flowers; blooms freely.

Jackmanni. Immense flowers of an intense violetpurple; bloom continually all summer.

Henyri. Flowers creamy-white and very large. A free bloomer.

Madam Edouard Andre. Flowers are a beautiful shade of crimson; a free bloomer. 
Ramona, A vigorous grower and perpetual bloomer; flowers a deep rich lavender.

\section{Small Flowering Varieties}

Coccinea. Flowers thick, bell shaped, of a bright coral-red color; blooms profusely.

Crispa. A slender dwarf variety with purplish flowers, bell-shaped, rather fragrant.

Flammula. Flowers small, white and sweetscented; needs plenty of sun.

Paniculata. Probably the most popular of the small flowering sorts; vine is a rapid grower with glossy, green foliage; in September the flowers appear in a perfect mass of white, giving the appearance of a bank of snow; the fragrance is most delicious and penetrating.

Virginiana (American White Clematis). Produces immense quantities of small white flowers in August; a very rapid climber.

Viticella. A well-known variety; produces a profusion of medium sized flowers of a bright wine-red color from June to August.

\section{HONEYSUCKLE. Lonicera}

Chinese Twining Honeysuckle (L. Japonica). A well-known vine, holding its foliage nearly all winter; blooms in July and September; very fragrant. Also known as the Evergreen Honeysuckle.

Hall's Japan Honeysuckle (I. Hallena). A strong, vigorous vine with pure white flowers, changing to yellow; foliage remains green well into winter; very fragrant and covered with flowers almost entire season. One of the best bloomers.

Japan Golden-Leaved Honeysuckle (L. Aurea reliculata). A handsome variety, with the foliage beautifully netted or variegated with yellow.

Monthly Fragrant Honeysuckle (L. Periclymenum, var. Belgica). Blooms all summer; flowers red and yellow and very fragrant.

Scarlet Trumpet Honeysuckle (I. Semper virens). One of the handsomest in cultivation; a strong, rapid grower. Flowers a bright scarlet; not much odor.

Yellow Trumpet Honeysuckle (I. Flava). A strong native vine with brightest orange-yellow, trumpet-shaped flowers.

\section{MADEIRA VINE}

Madeira Vine. A rapid climbing plant, with thick, glossy green foliage and fine white, fragrant flowers.

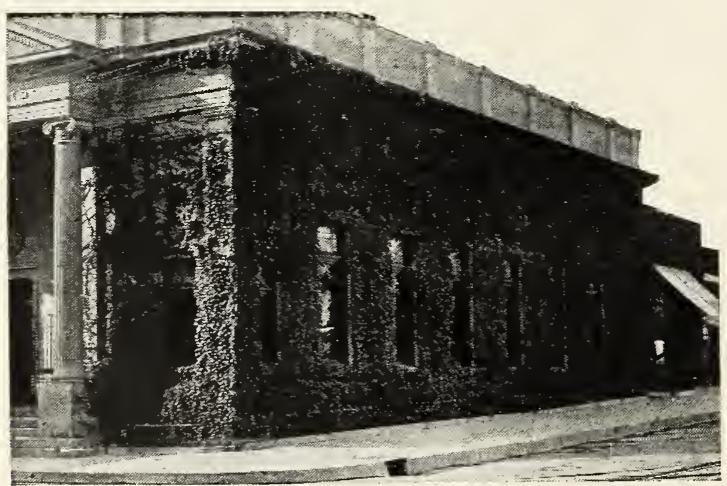

Ampelopsis Veitchii

\section{MATRIMONY VINE. Lycium}

Chinese Matrimony Vine (L. Sinensis). A creeping or trailing vine; foliage a grayish-green; flowers appear in June and continue blooming until September; color varies from pink to purple; fruits are a bright crimson and make a beautiful contrast with the green foliage. Valuable for trellises and fences.

\section{PUERARIA THUNBERGIANA. Kudzu Vine}

This is without a doubt the fastest growing vine we know of. Leaves are very large. We can recommend same to our customers wanting a vine for covering arbors and trellises; also porch growing.

\section{SILK VINE. Periploca}

Silk Vine (P. Graeca). Beautiful, rapid climber; splendid for training around pillars, trees or other tall supports; grows to 30 or 40 feet; foliage a smooth, glossy green and very showy; flowers a purplish-brown, borne in clusters.

\section{WISTARIA}

American Purple Wistaria (W. Magnifica). Flowers are borne in dense, drooping clusters of a pale blue color; vine vigorous, hardy, rapid grower.

Chinese Purple Wistaria (W. Sinensis). One of the best of the Wistarias; rapid growing and elegant; attaining 15 to 20 feet in a season; flowers a pale-blue, borne in long pendulous clusters in May and June.

Chinese White Wistaria (W. Sinensis, var. Alba). Same as the Chinese Purple, except the flowers are pure white; very beautiful variety.

\section{Deciduous Hedge}

\section{BARBERRY. Berberis}

Japanese Barberry (B. Thunbergii). A low, spreading bush, with small branches covered with small sharp thorns and in spring with small yellow flowers, succeeded by bright scarlet berries; foliage changes in the autumn to shades of scarlet and gold; makes a dense, thick hedge.

\section{HONEY LOCUST. Gleditschía}

Three-Thorned Honey Locust (G. Tracanthos). A rapid growing native tree with strong spines and delicate foliage. Very useful for hedges.

\section{OSAGE ORANGE. Machura}

Osage Orange (M. Aurantiaca). A native tree of medium size and spreading habit; leaves bright shining green, broad and sharp pointed; the fruit resembles an orange in size and color.

\section{JAPANESE QUINCE. Pyrus Japonica}

Scarlet Japan Quince (Japonica, var. rubra). A beautiful flowering shrub, suitable for hedges, thorny enough to form a good defense; flowers a bright scarlet crimson, in great profusion in the early spring.

\section{ALTHEAS, PRIVET, ROSES, RUSSIAN}

OLIVE, SPIREAS, TARTARIAN HONEYSUCKLE

For descriptions of above see index for pages. 


\title{
Herbaceous Paeonies
}

\author{
Varieties marked " $\mathrm{F}$ " are fancy.
}

The Paeonies are recognized as a fine, effective flower. They are extremely hardy and easily cultivated. The flowers are lasting and many of them are finely finished and exquisitely colored. No other hardy plant of our gardens thrives so well, nor has as much practical, permanent value.

In planting paeonies for cut flowers, do not plant a long list of varieties. For good results they must be cut at just the right time, which is hard to do if you have too many different varieties.

Andre Laures (Crousse 1881). F. Magenta red, fragrant. The last flower to bloom. Seldom misses.

Baron Jas. Rothschild. One of the best cheap flowers in our collection. Guard petals very regular, rose in color. Very compact bomb shape center of salmon, the tip of which shows purple.

Carnation (Terry). F. Very attractive, bright crimson, broad guard petals, inside finely fringed.

Asa Gray. Large, full bloom, perfect shape; guard petals salmon flesh, inner petals pink, sprinkled with carmine lilac.

Charles Verdier. Large lilac carmine bloom, transparent slate reflex. Compact and a good keeper as a cut flower.

Couronne d'Or (Crown of Gold, Calot). F. Imbricated petals. Compact solid white, with golden reflex. Center touched with carmine. A fine variety. Late and a good keeper.

Duchesse d'Nemours. Large and full; the most nearly pure white.

Duchesse d'Orleans. Very pretty, deep pink,

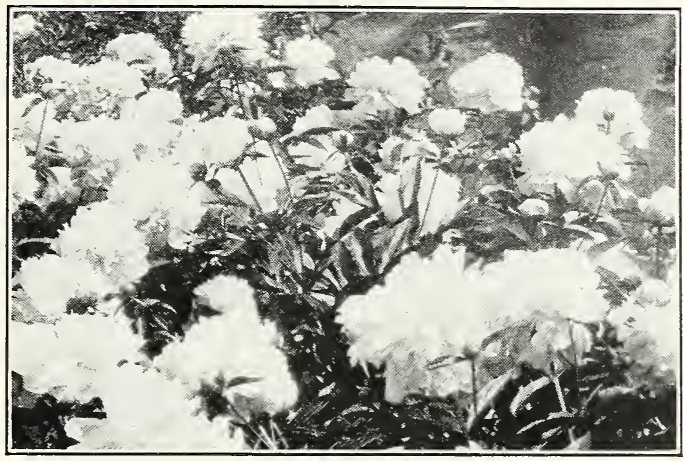

Herbaceous Paeony Bed

with violaceous tints on center petals, interspersed with salmon.

Dorchester (Richardson). F. A free blooming dwarf plant. Rose type, delicate light pink. Extra good.

Eugene Verdier. Salmon pink fading to white; strong, free bloomer.

Edulis Superba (Lemon 1824). A fine flower. Violaceous pink mixed with narrow whitish petals, giving a silvery reflex.

Festiva Maxima (Meillez). F. Glorious queen of the whites, often seren inches across. A large, loose flower of driven white, center marked with carmine. Perhaps the most popular paeony grown.

Faust (Meillez). F. Soft, lilaceous flesh colored, with deep chamois center; a full, shapely, splendid flower. Very desirable.

Felix Crousse (Crousse). F. One of the most resplendent of its class, rich brilliant ruby red of effulgent splendor. One of the best of the class of deep, glowing red.

Flambeau (Crousse). F. Very large, loose, pink, silver tipped.

Francois Ortegat. Old favorite; purplish-crimson, golden center.

General Custer (Terry). Very robust, large, variable pink, loose leaved, liberally sprinkled with yellow stamens.

Golden Harvest (Rosenfield). F. Soft pink, cream and gold and often in center a dainty Festiva Maxima, blood drops and all.

Grandiflora Alba. Early standard sort. Opens straw color fading to pure white. Tuft in center sometimes marked with carmine. Often sold for Festiva Maxima.

Grandiflora Carnea Plena (Lemon). Lilaceous mottled pink, one of the best keepers. Very charming, flowers in clusters. Should be in every garden.

Grandiflora Rosea (Guerin 1850). Fine, fragrant, rose pink, one of the surest bloomers.

Grandiflora Rubra. An old but very fine variety. Fine as a cut flower. Excellent for landscapes. 
Humei (Anderson). An immense late cinnamon scented flower of varnished pink. An old favorite.

L'Esperence. Very large sweet pink, fragrant. A great favorite.

Lady Bramwell. A ball of soft silvery-pink. One of the largest.

La Coquette (Guerin). Large pink crown, with a deeper pink center. A good bloomer and a very showy flower.

La Sublime (Parmentier). F. This is a fine flower of deep crimson. Very striking on account of its rich color. A reliable bloomer.

La Tulip (Calot). This belongs in a class by itself. The bud is very beautiful, interlaced with green and red. The flower is soft blush mingled with carmine, fading to pure white. Fragrant.

Louis Van Houttei (Calot). Vivid purplish-cherry. Very striking and satisfactory.

Labolas (Kelway). F. Japanese type. Rose purple. Broad guards, narrow short petals tipped yellow. A striking flower.

Modele de Perfection. Enormous cup-shaped bloom, very pink, bright rose, with silvery border, extra fine.

M. Vaillant (Calot). Immense, late, deep violaceous red. Synonomous Grandiflora Rubra.

Madam Jules Elie (Calot 1873). F. Large soft pink, silvery reflex. Fine.

Macl. Chaumy (Calot). Late, fragrant ball of pink, touched with silver.

Mme. Crousse (Calot). F. Splendid white, center sometimes edged with carmine; fragrant; one of the latest blooming whites; very choice.

Ime, d'Vernville (Crousse). F. Considered by Terry as one of the finest of all. Flowers of exquisite beauty, sulphur white, with broad guard petals; very attractive.

Mons. Dupont (Calot). F. One of our favorites; also one of the most reliable bloomers we have. Large, creamy white, tinged with brilliant carmine in the center. Makes a fine cut flower and is a good keeper.

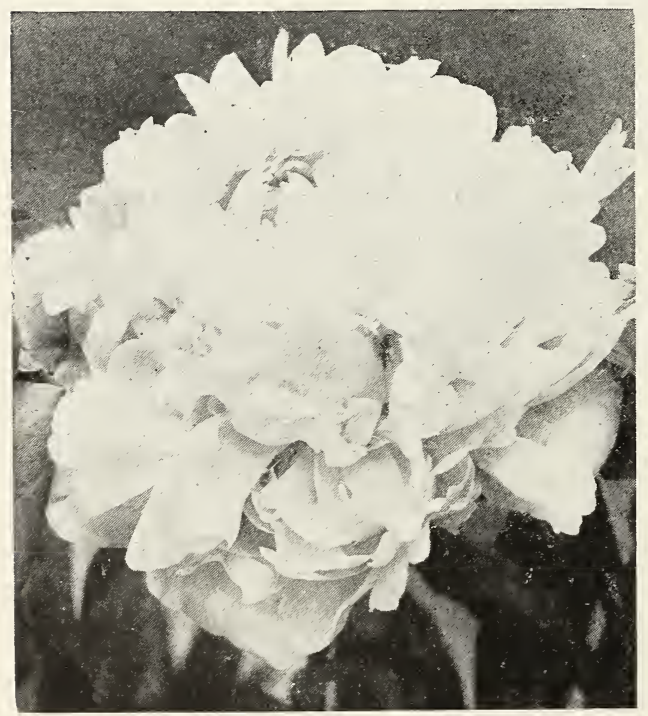

Ime. Crousse

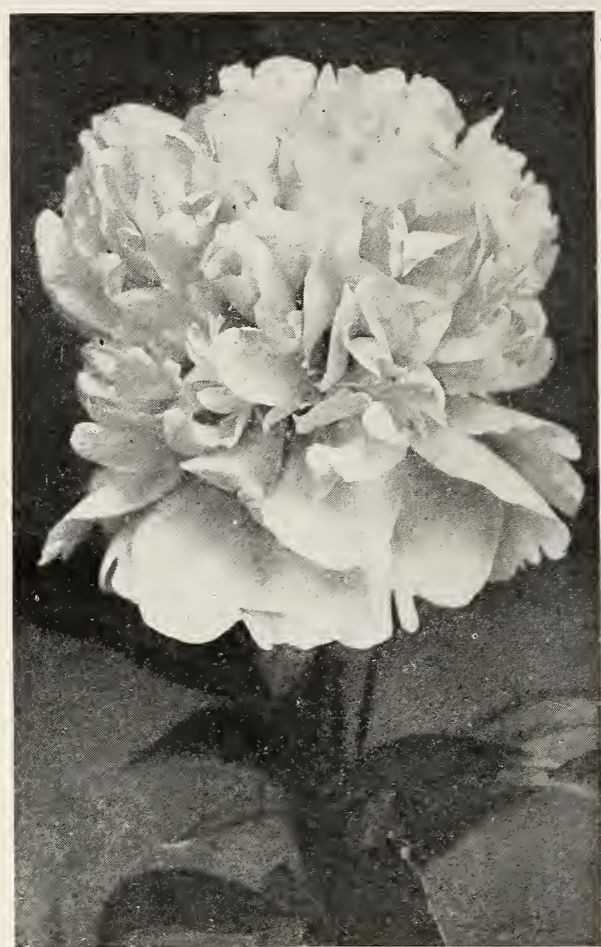

Queen Victoria

Mons, Paillet (Guerin). Large, compact, soft pink, liberally sprinkled with stamens. Petals have a waxy finish, a quality sign. A pretty flower.

Mons, Rousselon (Syn. Compte d'Paris, Guerin). F. Lilac pink, deep chamois center. A tuft of lilac pink petals in extreme center of bloom. Crown is generally flecked with carmine. A handsome flower.

Mons. Guerin (Guerin). Bears a profusion of bloom in clusters. One of the choice, reliable varieties. A compact, bright purplish-carmine.

Mons, Crousse. F. The American beauty paeony. A grand red; choice variety.

Pottsi. A very free blooming purplish-crimson. Early.

Prince Imperial (Calot 1859). Brilliant purplishscarlet; one of the best medium priced reds; flowers in clusters.

Plutarch. A glorious orb of radiant, glistening crimson.

Queen Victoria (English). Flesh fading to pure white; one of the florists' standard flowers. A great favorite.

Queen Victoria ('Terry). Pink blooms.

Reevesii (Mechin 1850). Very soft silvery pink. Choice.

Reine Victoria (Guerin 1845). Pink, tufted center.

Richardson's Rubra Superba. F. Rose type, large, rather compact bloom of deep red. Very late.

Thos, Meehan (Terry). F. Light rose tipped with silver; large, full flower and a free bloomer. One of the good medium priced ones. 
Umbellata Rosea. F. Light shell pink, upright habit, free bloomer and the earliest of all of the Chinensis family. In great demand for Decoration Day. We have grown this paeony for a number of years and it has never failed to produce bloom in time for Decoration Day trade.

Villa d'Nancy. F. Bright red. One of the most prolific and sure bloomers we have. Very desirable.

Weir's Crimson. F. Dark crimson; a free bloomer.

Wacht Am Rhine. F. Brilliant purple, violet shade; a good bloomer.

\section{JAPANESE PAEONIES}

This class represents the first change in the transformation from a single to a double flower. The stamens turn to narrow petaloids, producing different formations in the center. In some the tuft appears as a bunch of narrow ribbons with a stamen on the end of each ribbon. From others a tuft resembling colored corn silk hangs from the center. In short the formations are without number, with a wide range of colors. Like the singles they do not hold their petals long, but they are an oddity unknown by many. They are on their way and you cannot always depend on them. Some spring you may see that your Jap has turned to one of the most gorgeous double flowers. This year our seedlings brought us over 200 double flowers, some of them far ahead of anything in the imported line we have yet seen.

\section{OFFICINALIS (Old Fashioned Type)}

Rubra. The early intense red. Blooms before Decoration Day.

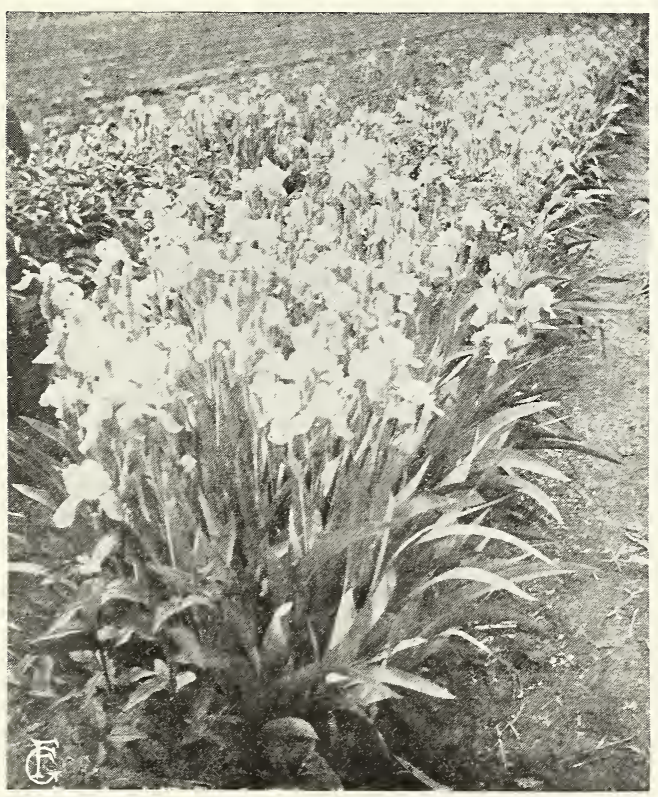

German Iris

Alba. A variable white.

Moutan or Tree Paeony. F. These differ from the Herbaceous paeony by assuming a dwarf shrub effect which in time reaches a height of 3 to 4 feet. The flowers are large and of delicate shades.

\section{THE IRIS}

The Iris is the rainbow personified. A goddess who visits us in garments of indescribable splendor and while she is with us we are in wonderland. The lure of her loveliness is irresistable. The delicacy, refinement and harmonious interweaving of colors in which she is clothed is beyond the brush of man. Wherever invited they become favorites and their fame is spreading and the day is fast approaching when they will have their rightful place in every garden.

Some of the new varieties are exceedingly beautiful. There is an infinite range and variation of color. The winsome, modest beauty of some, forming a striking contrast to their more glorious sisters arrayed in a sheen or irridescent splendor. There is no flower that will give you a greater range of color for your garden and by purchasing the different varieties you will have bloom from April until the middle of July. Much care was taken in obtaining our descriptions and we know that they are true and complete.

Flanting. German Iris succeeds in partial shade, but they are at their best in the full sun. They will grow most anywhere, but do best in a well drained rich loam or garden soil. They should be planted very early in the fall or very early in the spring. Plant the bud or crown about two inches below the surface.

The Siberian type is hardy as an oak, and very beautiful. Plant as you would the German.

The Japanese like a moist earth and a moist air. They will do well planted along streams or ponds. If planted on high ground they should be watered until blooming season is over. They produce large flowers of great beauty. They are very attractive.

\section{IRIS GERIMANICA \\ Tall Bearded Irises}

The upright or standard petals are indicated by $\mathrm{S}$, the drooping petals or falls by $\mathrm{F}$.

Black Prince. Bears many other names. A strikingly beantiful flower. Large and conspicuous petals of dark purple veined at the base. No collection should be without it. Medium height. 
Bergiana. S and inner petals pure gold. F, maroon with rich golden tracing. Medium height.

Cherion (Syn. Nemises). S, smoky lavender, inner petals lavender and straw; F, lilac finely veined. A tall flower.

Celeste (Syn. Lady Francis). This is one of the purest and sweetest of flowers. S, pale blue of ultra marine cast; F, light violet edged lighter, golden beard. Tall.

Chalcedonia (Syn. Johan d'Worth-Brooklyn). An old sort of medium height. S, light mauve; F, purple, heavily veined. A prolific bloomer.

Delicata. S, pale lavender; F, white, veined and edged lavender; medium height.

Elizabeth. S, pale lavender, darker in the center. $\mathrm{F}$, mauve, melting into pale blue. A very large, attractive flower. Medium height.

Elegans (Syn. Vidonne, La Martine). A very winsome flower. S, nearly white, dashed and splashed with violet. These markings are striking and unusua!. Inner petals light lavender; F, violet veined with white. Sometimes variable in bloom. A beautiful flower.

Florentina Alba (Syn. Silver King). Porcelain, changing to pure white. Medium height.

Gracchus. Medium height. S, pure lemon, inner petals also yellow; $\mathrm{F}$, violet, completely interwoven with delicate tracery.

Her Majesty. Very attractive on account of its rich and unusual color. $S$, heliotrope of tissue-like delicacy, inner petals straw and lavender; F, light mauve traced with white. A very fine rich flower. Medium height.

Honorablis. S, intense yellow; F, bronze. Much like San Souci, only a taller growing plant.

Jacquesiana. Tall growing. S, bright coppery crimson. F, rich dark maroon, veined with white near base.

Khedive. Tall. S, clouded lavender veined at the base. Inner petals light lavender flecked with white. F, dark lavender, orange beard. Tall.

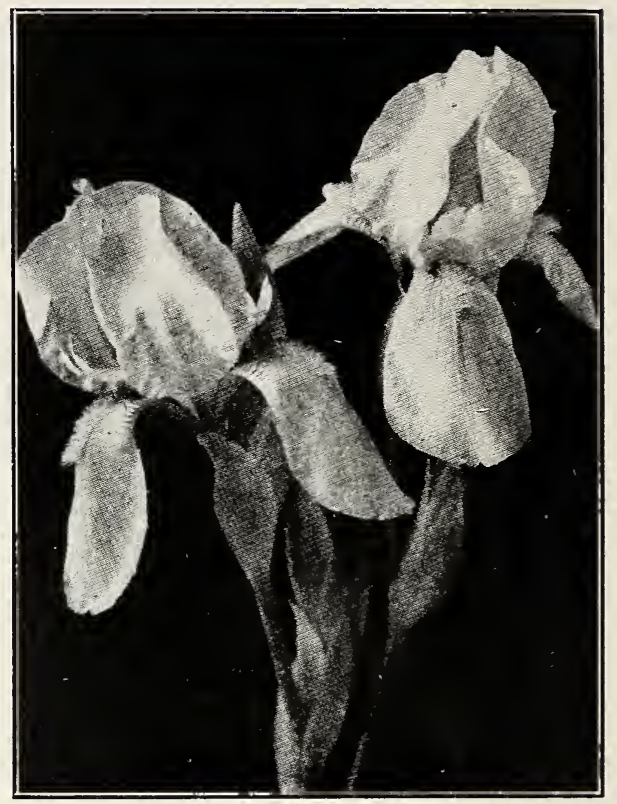

Florentina Alba

Lady Jane. S, light lavender, charmingly veined at the base. F, fawn color traced with heliotrope. A choice flower. Medium.

La Tendresse. A charming, delicate, fragile flower. S, lavender; F, lilac color. Medium.

Leonidas (Syn. Murat, Yolandie). Of radiant beauty. S, purple; F, dark purple, with glistening sheen. Very handsome. Tall.

Madam Chereau (Syn. Imogene). A tall, stately, queenly flower. If new it would be in great demand. S, white, edged and fringed mauve inter-

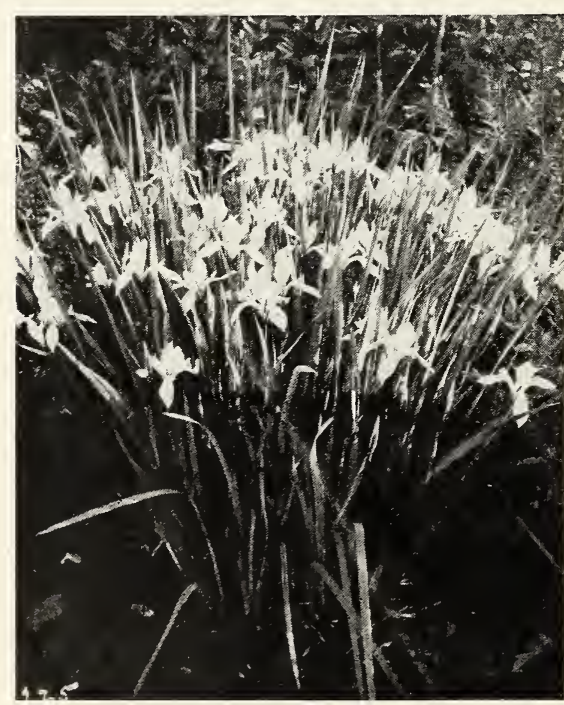

Dwarf Bearded Iris spersed with lilac. Inner petals white; F, white edged, the same as the standards.

Madam Pacquette. S, very delicate light purple, inner petals lavender striped with heliotrope; F, are of great beauty, these are of deeper purple, very large, with threads of violet. A strikingly beautiful flower. Tall.

Monhassan. S, golden yellow; F, white and yellow, veined and mottled with brown. Medium.

Nymph. S, pale lavender, shaded darker, inner petals light lilac and yellow. F, purple, reticulated white. Medium.

Purple Queen (Syn. Florentina Blue, German Blue, Blue Beard Parensis). Very robust plant, large purple flower, petals velvety purple, very showy and imposing.

Pallida Dalmatica. The noblest of all the Iris family, height three feet or better. Foliage broad and ornamental when flower is in bloom. Large pale blue flowers, very fragrant. A beautiful flower.

Perfection. S, mauve often dashed with deeper colors, inner petals mauve lavender; $\mathrm{F}$, droop outward to show the most beautiful soft velvety petals ever possessed by a flower. The color is rich deep violet veined and traced in the most exquisite manner. A magnificent flower, borne on stems three to four feet tall. Rare.

Queen of May. A soft rose lilac, almost pink, a color rare among Irises. Medium. 
Rosamond (Syn. Dove). S, lavender buff; $\mathrm{F}$ is darker.

Sambucaina Beethoven (Syn. Miss Brough). Not a large flower, but a very pretty one. S, lilac, finely reticulated, inner petals light yellow; F, rosy purple, with orange crest. Very striking. Medium to tall.

Sans Souci (Syn. Rebecca). This is a hardy plant and a prolific bloomer. Fine for massing and for a border effect. S, canary, base reticulated dove color. F, yellow, charmingly veined and interlaced with brown fading to light maroon. Medium.

\section{DWARF BEARDED IRISES}

\section{Pumilla and Hybrid Crimean Varieties}

These lovely Irises are very suitable for border effects or for planting in front of the taller growing varieties. They commence to flower the last of March and are in bloom until about the time the German Iris comes into bloom. Postpaid, 4c additional.

Pumilla (the old-fashioned Flag). Rich blue, lilac, purple and other colors.

Verna. Flowers violet purple, yellow at the base.

\section{Other Varieties}

Aurea (From the Himalayas). A handsome flower of deep golden yellow.

Orientalis Gigantea. Very tall grower, handsome foliage, flowers of ivory whiteness with an orange yellow blotch at the base of the falls.

\section{SIBERIAN IRISES}

We strongly recommend these hardy Irises. They have handsome foliage and beautiful flowers and will survive extremes of weather and other

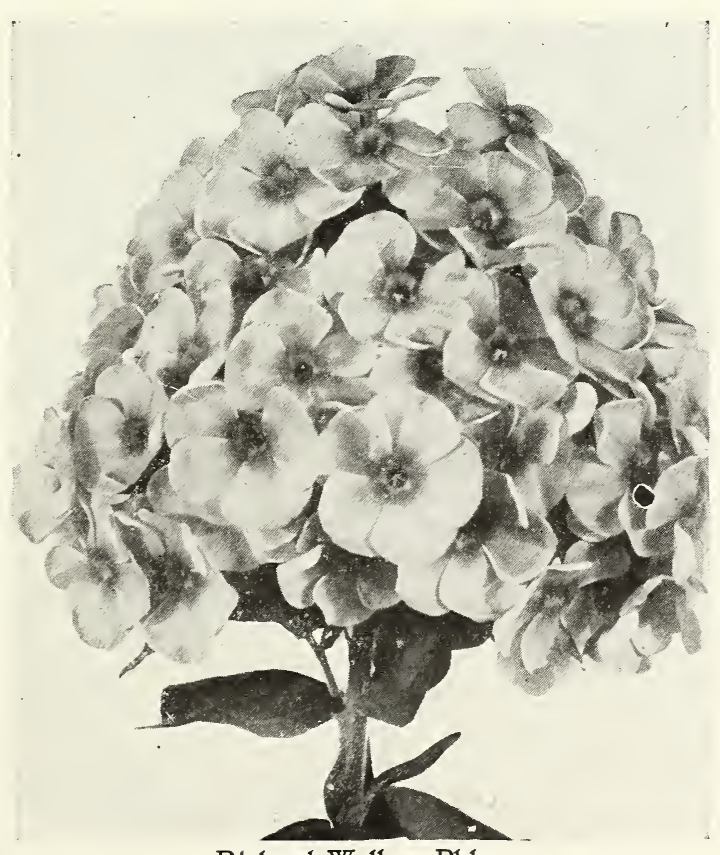

Richard Wallace Phlox untoward condition that prove fatal to other perennials. There is no other firm that has as many varieties of these as we have, and we are so well pleased with them that we intend to increase this list as fast as dependable varieties can be obtained.

Acuta. Blue, interlaced with white.

Lactea. A tall growing milky white.

Orientalis. Tall growing. S, violet; F, rich bluish violet.

Siberica (Siberian Blue). Rich blue flowers of exquisite beauty. Much prized as a cut flower. Very choice.

Siberica Alba (Siberian White). Has a beautiful whiet flower. Choice.

Snow Queen. S, white; F, white, golden yellow at the base. The color is so intense it gives a golden reflex inside the flower. This is a rare and beautiful flower borne on tall strong stems. A flower we strongly recommend as well worth while.

\section{PHLOX}

The Phlox will always continue to be an old standby. They take you through the trying heat of July and August; a perfect mass of bloom when many other summer flowers are gone. Commencing to bloom in June they continue until it freezes up in an endless variety of colors. Planted in masses they present a charming appearance, while the lower growing varieties used as a border produce a very striking effect. They have a very sweet and delicate fragrance.

Arete. A cross between the Richard Wallace and Crepuscule. Symmetrical head and is a prolific bloomer, and florets large white with red center. In cool weather tinted with lavender. Medium height, very robust, resisting the heat and also the blight in wet weather. Rapid multiplier, and very desirable.

Crepuscule. We consider this the finest phlox in the world. Single flowers much larger than a dollar; massive heads, which at a distance look like one enormous flower. In color, white shaded violet, striking large purple carmine eye.

La Nuit. Purplish garnet; large florets ; a beautiful flower. Medium.

Lothair. Deep clear rose, large carmine eye. Medium.

Le Pole Nord. Very tall, late variety with white floret and red eye.

Miss Lingard. Longest spikes of any phlox; blooms from the ground up. Waxy white, lavender eye.

Pyramid. Dwarf early white; compact head and a free bloomer. One of the most satisfactory phloxes we have. A rapid multiplier.

Richard Wallace. Very robust plant, large full head, white with crimson eye.

Zouave. Medium size, fine red. A ready propagator, very desirable. 


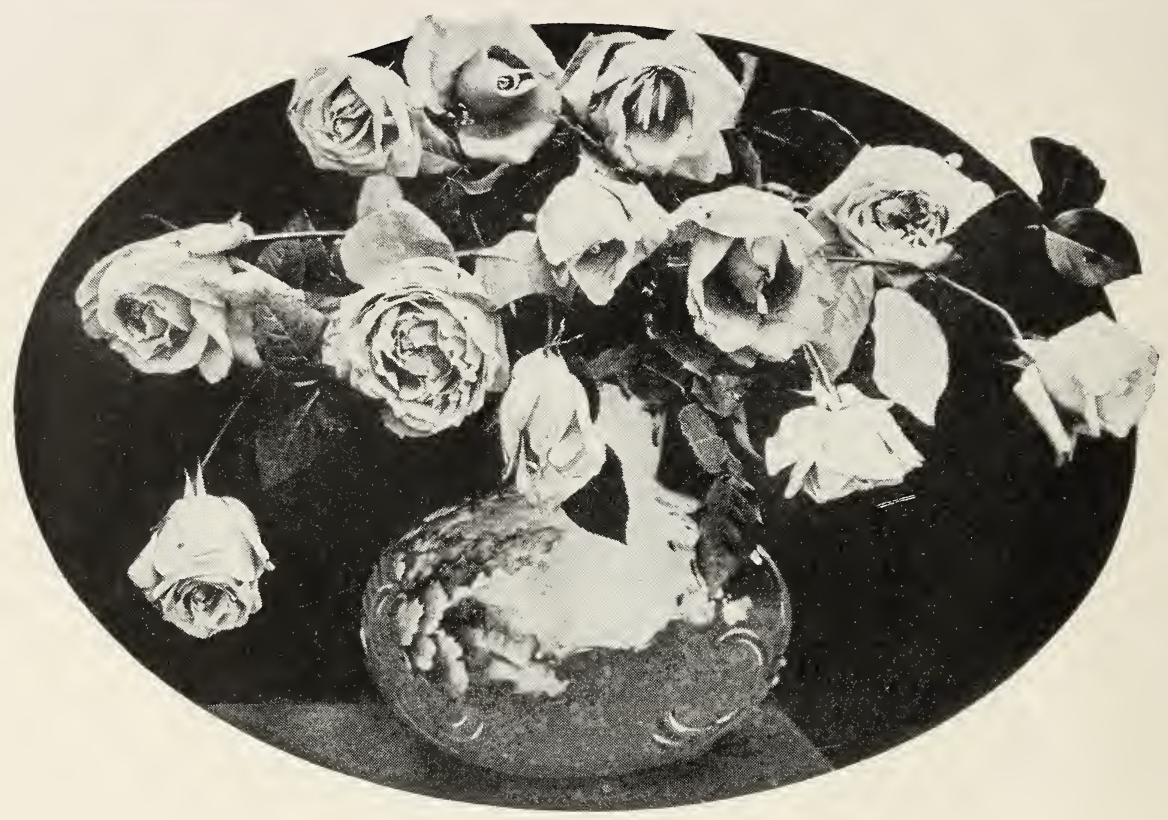

\section{Roses}

A mong all the flowering shrubs that make for beauty, grace and ornamentation, there is none that can compare with the Rose. The wide range of color, shape and size of the blooms and the diversity and character of the foliage gives it a wider range for decoration than any other single group of plants. When added to these qualifications are ease of culture, quick and ample response in blossoms, it is not to be wondered that the rose has been aptly termed the "Queen of Flowers." In most collections of flowering or ornamental shrubs it is in first place.

\section{CULTURAL DIRECTIONS}

Roses thrive best in a clay loam enriched with well-rotted manure. They should also have an open, airy situation unshaded by trees or buildings wherever possible. Dig up the soil thoroughly to a depth of 12 to 15 inches. Soak the beds occasionally with weak manure water. At time of planting cut the stems off to within three inches of the trunk or parent stem. Plant the roses deep, covering up all of the main trunk or parent stem and about an inch of the branches. If this is not done the sun and hot winds will kill the bud and later on shoots will appear from the roots which of course would produce the wild rose. All rose bushes except climbers should be cut off to within three or four inches from the top of the ground about the middle of Octobereach year and covered over with litter or banked with dirt, and then uncovered in the spring. By handling roses in this manner you will succeed in maintaining the double rose from year to year. Otherwise they will degenerate.

\section{HARDY ROSES}

Roses delight in an open, airy situation, unshaded by trees and buildings. Always plant in solid beds and each class by itself. Hardy roses may beplanted in the fall or spring, but for this latitude we recommend spring planting. Dormant plants set in the spring should be planted early, before growth is started.

As roses are raised mostly for their flowers, it is necessary to give that culture to the plant best adapted to produce this result. A very rich soil is of the first importance and it must be made so by thoroughly working in plenty of old composted stable manure in which leaf mold has been decomposed.

All roses should be cut back closely at the time of planting. For Hybrid Perpetuals remove at least one-half of the previous year's growth annually in the spring. In the ever-blooming class twothirds of the previous year's growth. Strong growing varieties require less pruning back than weak ones. As soon as severe freezing weather sets in, raise the earth around the plant 3 to 4 inches, with leaves, straw or mellow soil.

Insects and Diseases. It is very important to keep your plants healthy and vigorous and free from diseases and insects. If troubled with green fly, spray vigorously, covering thoroughly every part of the foliage with sulpho-tobacco, soap or kerosene emulsion, made by mixing two parts of kerosene with 
one part of sour milk. Dilute with twenty parts of soft water. Bordeaux mixture is one of the best preventives from mildew and black spots, which are fungous diseases usually caused by continuous wet weather. By careful attention the diseases and insects may be kept down and plants will reward you with their beautiful blooms and foliage.

\section{HYBRID PERPETUALS}

Alfred Colomb. Brilliant carmine-crimson; very large, full and globular shaped; very fragrant and a superb rose.

Anne de Diesbach. Beautiful shade of carmine; very large and fragrant; quite hardy and a good forcing rose.

Baron de Bonstetten. Rich, velvety maroon, large and full; a splendid sort.

Baroness Rothschild. Light pink; a fine show rose, but without much fragrance; hardy and a late bloomer.

Captain Hayward. Very large, bright carmine-crimson; vigorous and free flowering.

Clio. One of the best; large, fine, globular form, flesh color, shading to rose in center; very vigorous.

Coquette des Alps. White, tinged with carmine; very fine; a free bloomer.

Coquette des Blanches. A pure white rose, very beautiful; one of the best of the white sorts.

Eugene Furst. Velvety crimson, shading to a rant and beautiful.

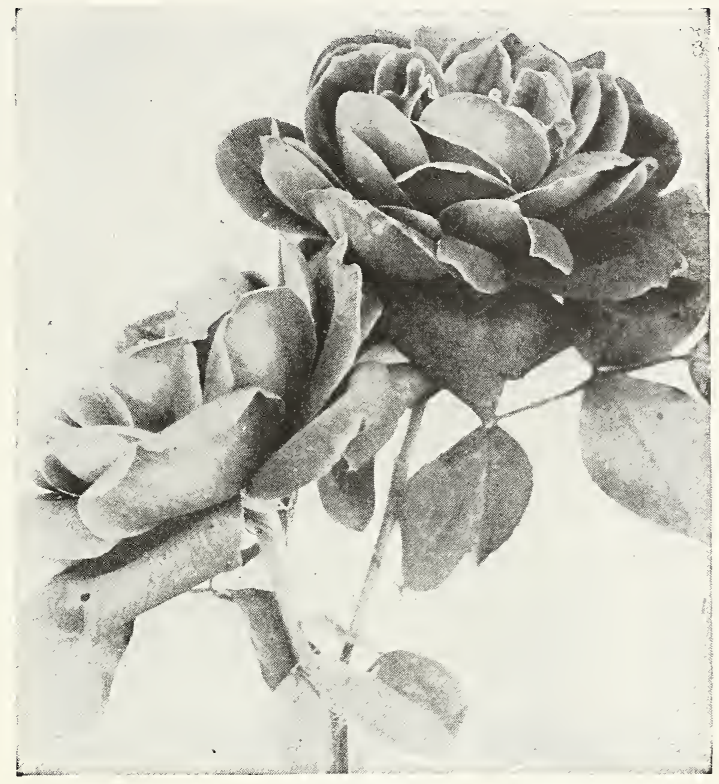

Paul Neyron

Francois Levet. A splendid rose; cherry-red; medium size, well formed; vigorous and a free bloomer.

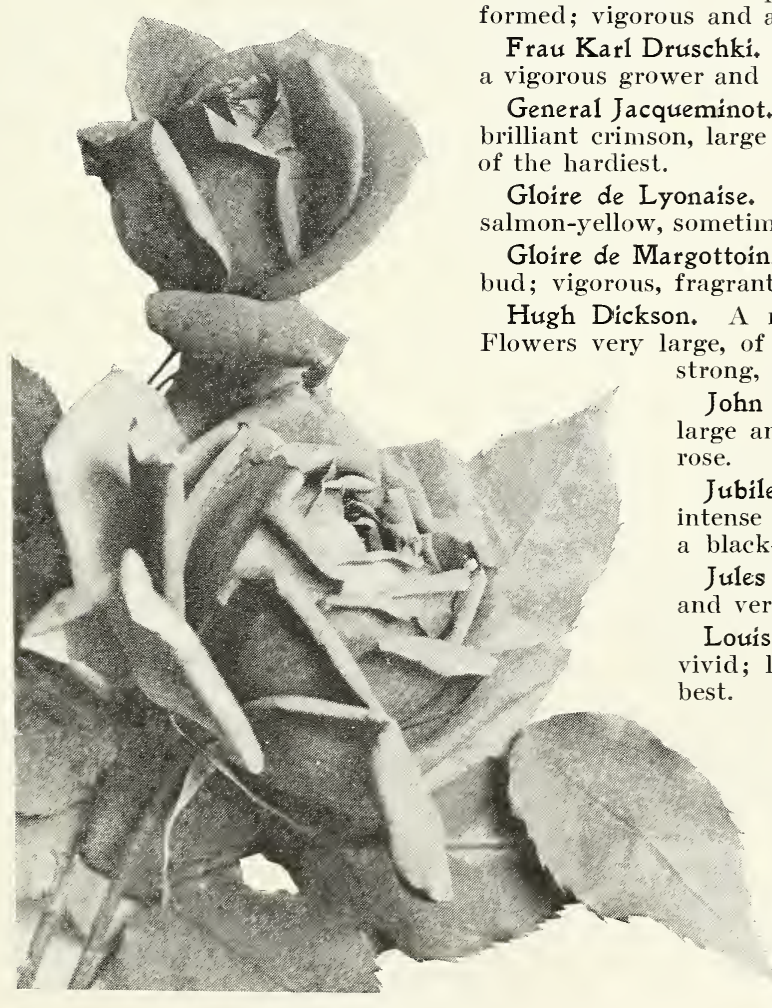

Captain Hayward best.

Very large, perfect form and snow white

minot. One of the most popular of the red roses; crimson, large and very effective, very fragrant and one

Gloire de Lyonaise. A grand rose; a beautiful shade of pale almon-yellow, sometimes passing to creamy white; very fragrant.

Gloire de Margottoin. Brilliant scarlet; large semi-double, long ; vigorous, fragrant and a free bloomer.

Hugh Dickson. A magnificent crimson, shaded with scarlet. arge, of perfect shape and fully
strong, vigorous and productive.

John Hopper. Bright rose with carmine center; arge and full; very free bloomer and a standard

Jubilee. A splendid large flowering variety of intense color, bright maroon-crimson, often almost black-red; very showy; fragrance very lasting.

Jules Margottin. Bright cherry-red; large, full very fragrant.

Louis Van Houtte. Red, shaded crimson, very ivid; large and fine form; fragrant; one of the

Mabel Morrison. White tinged with blush; a very valuable white rose.

Magna Charta. Extra large and full, bright rosy-pink; a profuse bloomer and very hardy.

Margaret Dickson. Beautiful form, white with pale flesh center; petals very large; fragrant.

Marie Bauman. Brilliant carmine-crimson; large, full and very fragrant; extra fine. 


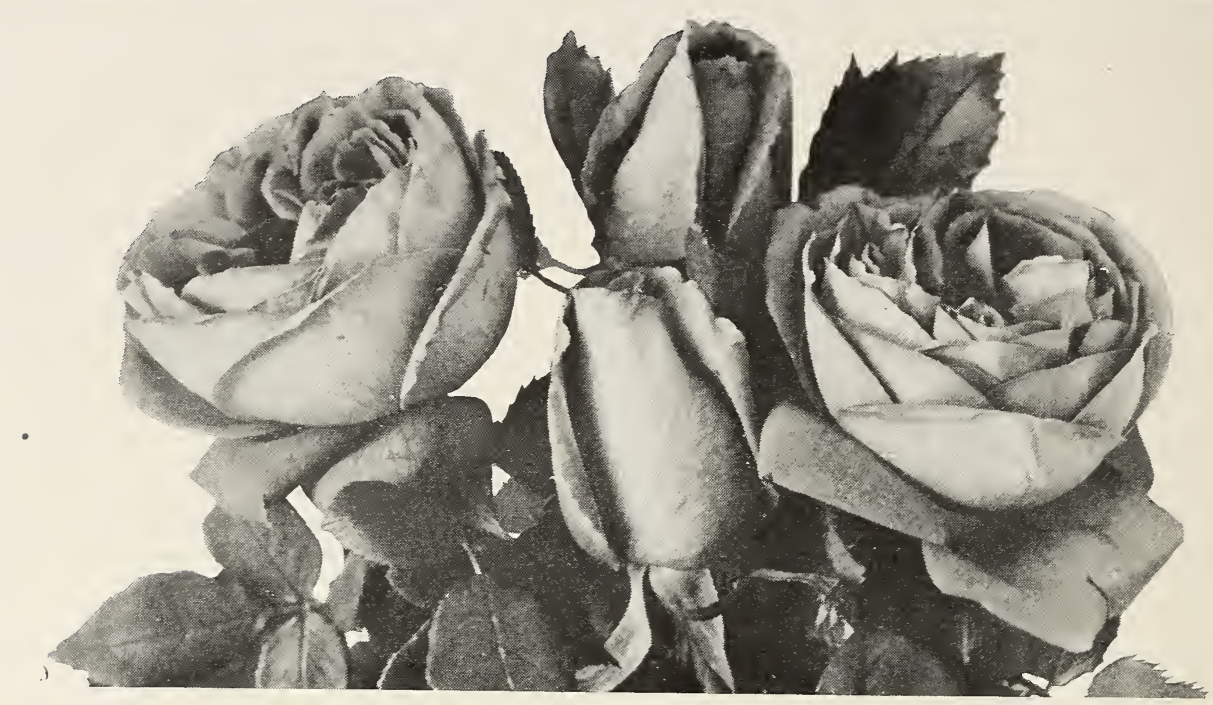

Ulrich Brunner

Marshall P. Wilder. Extra large, full deep red; a free bloomer and very handsome.

Mrs. John Laing. Soft pink, beautiful form, exceedingly fragrant and very free flowering.

Mrs. R. G. Sherman-Crawford. Deep rosy pink. very double and full; vigorous and a free bloomer.

Paul Neyron. Said to be the largest rose in cultivation; bright, clear pink, very fragrant, hardy and a strong grower.

Prince Camille de Rohan. Very dark, relvety crimson, almost black, large and full; a beautiful sort.

Soliel d'Or (Sun of Gold). A strong, hardy rose; large, full and double; golden orange-yellow tinged with red and rosy-pink; a magnificent rose.

Silver Queen. Lovely silver rose, passing to

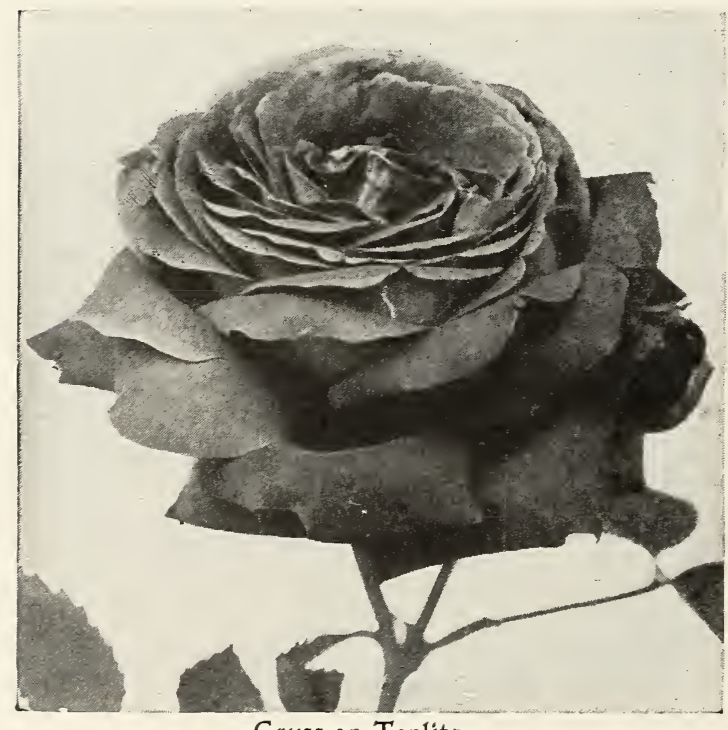

Gruss an Teplitz delicate rosy-pink; delightfully fragrant and a free bloomer.

Tom Wood. Very large, bright cherry-red with shell-shaped petals.

Ulrich Brunner. Rich crimson-scarlet, highly perfumed, vigorous and hardy; very desirable sort.

Vick's Caprice. A fine striped rose of great beauty; full, double and finely formed; deep clear pink, striped with white; hardy and a good bloomer.

\section{CLIMBING ROSES}

Baltimore Belle. A rapid growing, dark leared Prairie Rose; blooms in large clusters of pale blush and white flowers late in the season.

Multiflora Japonica. Single white; fragrant; very pretty.

Prairie Queen. A rapid climber; flowers are very large; a bright rosy-red, changing lighter as the flowers open; strong and rigorous.

Seven Sisters. One of the best of the oldfashioned sorts; flowers borne in clusters; color varies from dark to light red or pink.

\section{RAMBLER ROSES}

Crimson Rambler. The best-known and most popular of all the climbing roses. A rapid grower, making sometimes 15 to 20 feet in a season; flowers are borne in clusters of 15 to 25 perfectly shaped blossoms of a rich glowing crimson; when in full bloom the vine appears to be a perfect mat of rich red flowers; perfectly hardy ererywhere.

Dorothy Perkins. This is one of the new Rambler types; has the same strong habit of growth as the Crimson; flowers are borne in large clusters of 25 to 30 and are a beautiful shell pink; the individual flower is larger than the Crimson Rambler. A valuable acquisition to the climbing roses.

Red Dorothy. Among Rambler roses none has gained greater popularity than the beau- 
tiful pink Dorothy Perkins. The Red Dorothy is a duplicate except in color.

Lady Gay. Another new type fully equal to the Crimson; bud opens a deep pink, shading to almost pure white when flower is matured; borne in large clusters and very double.

Philadelphia. A splendid climbing rose with flowers more than two inches in diameter; very double, deep rich crimson, more intense than the Crimson Rambler; borne in large clusters completely covering the bush; the flowers hold their color for a long time; vine is very hardy and a strong grower.

Pink Rambler. Flowers are double, of a clear shell pink; borne in large clusters. A valuable rose for cutting.

White Rambler. Flowers are pure white, very double and remain on the vine a long time.

Yellow Rambler. Same as the pink, excepting flowers are a light yellow, changing to straw color; very fragrant.

Trier. A strong-growing climber of the Rambler type, with great trusses of pale rose-colored flowers, changing to white. Blooms continuously all summer.

\section{CLIMBING TEA and NOISETTE ROSES}

Climbing Meteor. A rich velvety crimson, strong-growing shoots 12 to 15 feet long in a single season; one of the best ever-bloomers.

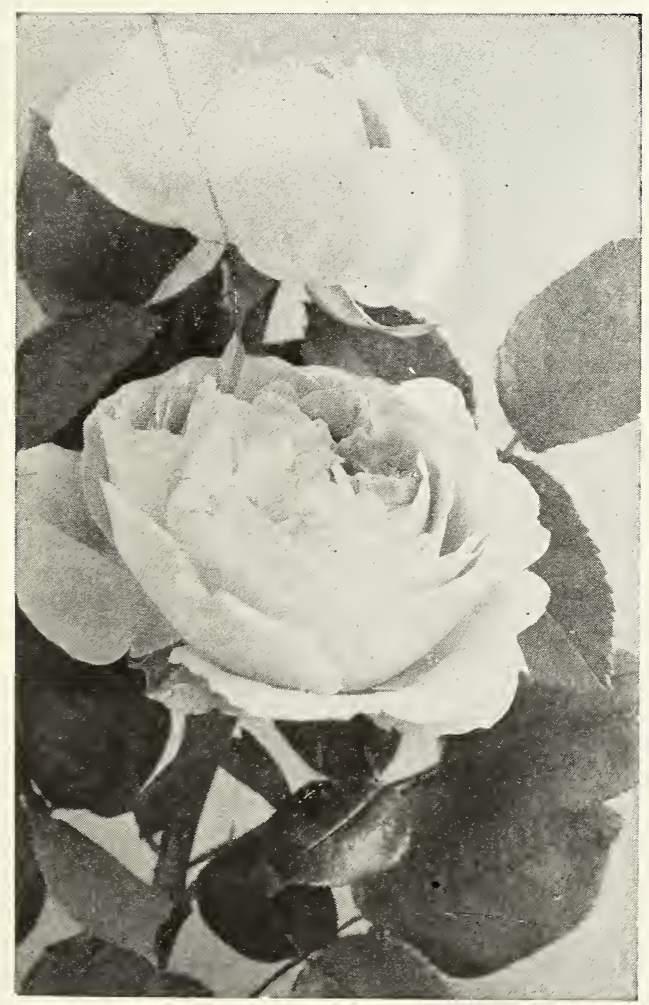

La France

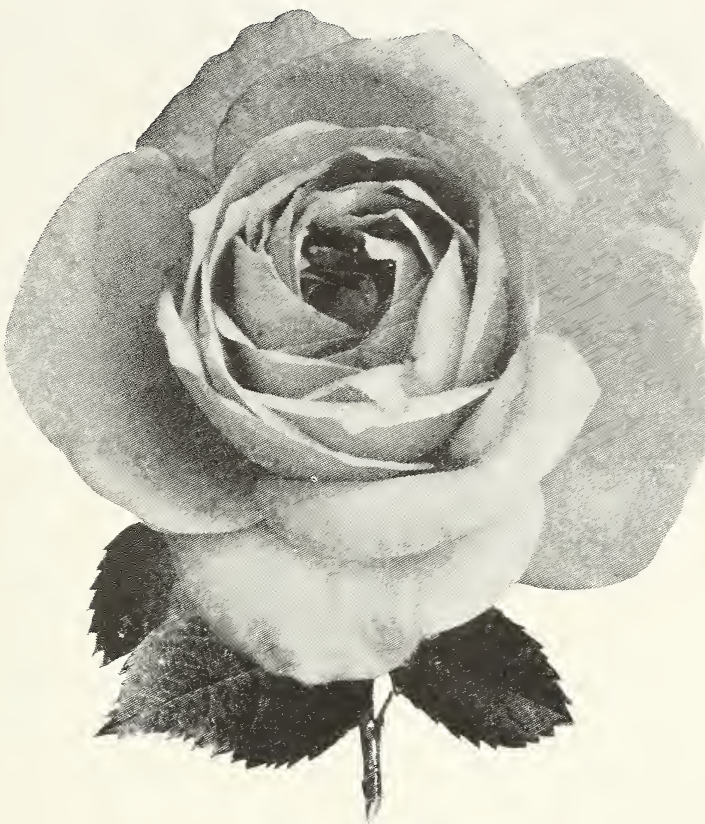

Margaret Dixon

Marechal Niel. Beautiful deep yellow, large, full and of a globe shaped form, very highly perfumed.

William Allen Richardson. Flowers are a beautiful orange-yellow, medium size, very showy and distinct. One of the most valued of the climbers.

\section{FIELD GROWN TEA AND HYBRID TEA}

Especial attention is directed to this selection of choice roses which we have grown outdoors, and now offer in strong two-year size. As the stock is limited, orders should be placed early to insure acceptance.

American Beauty. The flowers are a deep crimson color, of very large size, and the most fragrant of its class. It is a continuous bloomer. Should be protected in winter.

Burbank. Bright cherry-crimson flowers of great substance and durability. Does well outdoors.

Gruss an Teplitz. One of the richest colored roses grown. When first opened, it is dark, rich crimson, which quickly changes to bright scarlet, shaded with velvety fiery red.

Hermosa. Always in bloom and very fragrant; a most pleasing shade of pink.

Kaiserin Augusta Victoria. A beautiful rose, with elegant, large pointed buds and very large, full double flowers; color, delicate creamy-white; deliciously fragrant. The plant is a strong, healthy grower and constant bloomer, one of the choicest and most trustworthy garden roses.

Killarney. Queen of the Irish roses, of exquisite form and fragrance. Bright carmine-pink, marbled in creamy-white, with petals large and durable; the buds extremely long.

La France. Delicate silvery-rose, shaded with cerise pink, often silvery-pink, with peach shading. 
Mamam Cochet. A valuable pink bedding or pot rose, with rich, healthy foliage and large flowers on long, straight stems; color, deep rose-pink, the inner side of petals silvery-rose.

White Mamam Cochet. A beautiful snow-white, sometimes tinged with the faintest suggestion of blush. Hardy, with but slight protection.

\section{HYBRID TEAS}

Auguste Guinnoisseau (White La France). Flowers extra large, full, pure white, delicate, shaded with soft rose, very fragrant.

Helen Gould (Baldwin). Flowers very large, perfectly double and very sweet; color a rich bright crimson with beautiful shades of pink; very hardy, strong, vigorous grower and produces great quantities of flowers. One of tlie very best.

Souvenir President Carnot. Lovely shell-pink, delicately tinted with golden fawn or rich cream white. A very desirable rose.

\section{POLYANTHA ROSES}

Clotilde Soupert. Flowers are borne in large clusters all over the bush; large, full and double; very fragrant; beautiful cream-white, tinged with amber at center and clear bright pink.

Crimson Baby Rambler. One of the best hardy bedding roses; vigorous and grows 18 to 24 inches; flowers are borne in clusters of $\mathbf{2 0}$ or more to the cluster. Perfectly hardy and is good for pot culture for winter blooming. Color a bright crimsonpink.

Pink Soupert. A new ever-blooming rose, as beautiful as Clotilde Soupert, but deeper color.

Pink Baby Rambler (Anna Mueller). Of the same free flowering class as the Crimson Baby Rambler. Blossoms a shade of deep rose with petals curled and twisted, producing a fluffy effect. Hardy, vigorous grower and foliage very beautiful.

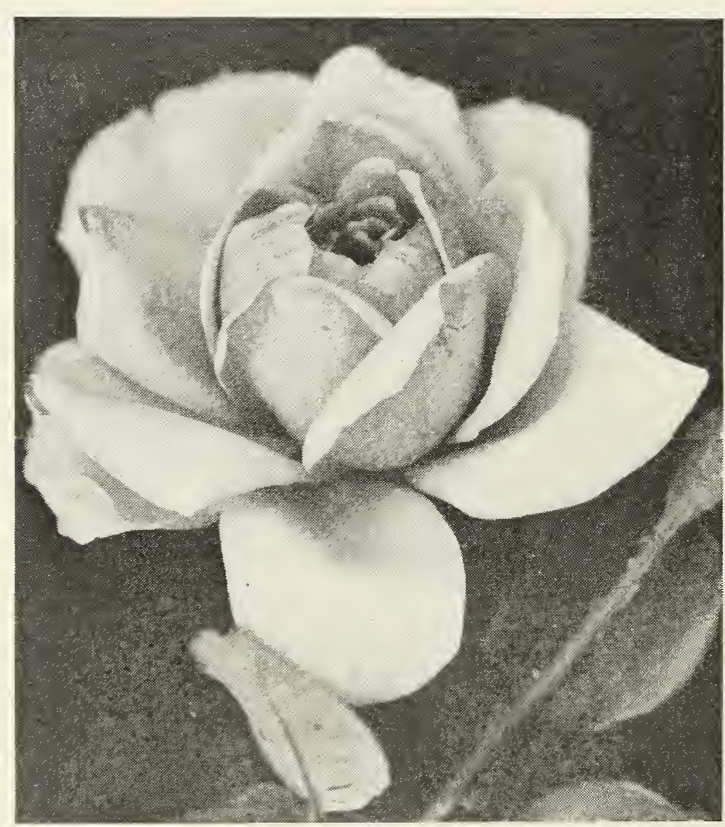

White Mamam Cochet

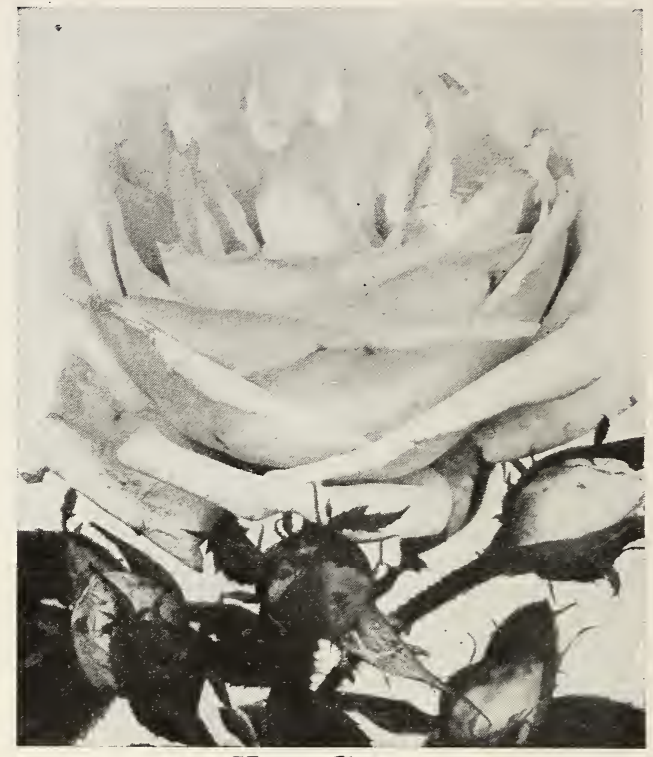

Magna Charta

White Baby Rambler. Blooms all summer and blossoms are produced in great abundance. Creamwhite, passing to snow-white.

Baby Dorothy Perkins. Pink.

\section{JAPANESE TRAILING ROSES Wichuriana Hybrid}

Manda's Triumph. Flowers are medium sized, perfectly double, pure white and very fragrant; plant an erect grower; dark green foliage, and is very hardy.

Pink Roamer. Flowers are single, and from two to three inches in diameter; rich pink, with silvery-white center and orange red stems; exceedingly fragrant.

South Orange Perfection. Belongs to the Pink Roamer class, and blooms freely in clusters; color rosy blush, changing to white; flowers are perfect rosettes in form.

Universal Favorite. Flowers are bright pink, double and in every way equal to the double white varieties.

\section{TREE ROSES}

These are grafted on stems from four to five feet high, forming a head that is somewhat tree-shaped. They may be planted in tubs, and make very ornamental additions to lawns, verandas, etc. Can be supplied in leading Hybrid Perpetuals, Crimson Rambler, Baby Rambler, etc.

\section{MOSS ROSES}

Blanch Moreaur. Pure white, large and full, perfect form and well furnished with deep green moss. Very strong grower.

Captain John Ingram. Dark relrety purple, large size, double.

Countess of Murinais. One of the best pure white moss roses. Flowers large, full and fragrant; a good bloomer. 
Crested Moss, Deep pink colored buds, surrounded with a mossy fringe and crest; a very fragrant and beautiful variety.

Glory of Mosses. A moderate grower; flowers very large, color a pale rose.

Henry Martin. Medium size, flowers large and rosy-red, well mossed, fragrant.

John Cranston. Deep crimson; very double.

Luxemberg. Bright crimson, large and beautifully mossed.

Princess Adelaide. Extra large, flowers very double and sweet, color bright rosy-pink; moss a bright green.

Perpetual White. Pure white with a nicely pointed burr. One of the most beautiful white varieties.

Paul Fontaine. Deep crimson; constant bloomer.

Salet. A bright light rose, large and full. It sometimes blooms in the autumn.

\section{MISCELLANEOUS ROSES}

Harrison's Yellow. Bright golden yellow, very hardy; fine for planting in groups; early bloomer.

Madam Plantier. A pure white rose recommended for lawn and cemetery; plant does not winter-kill and is a strong, vigorous grower and an enormous bloomer.

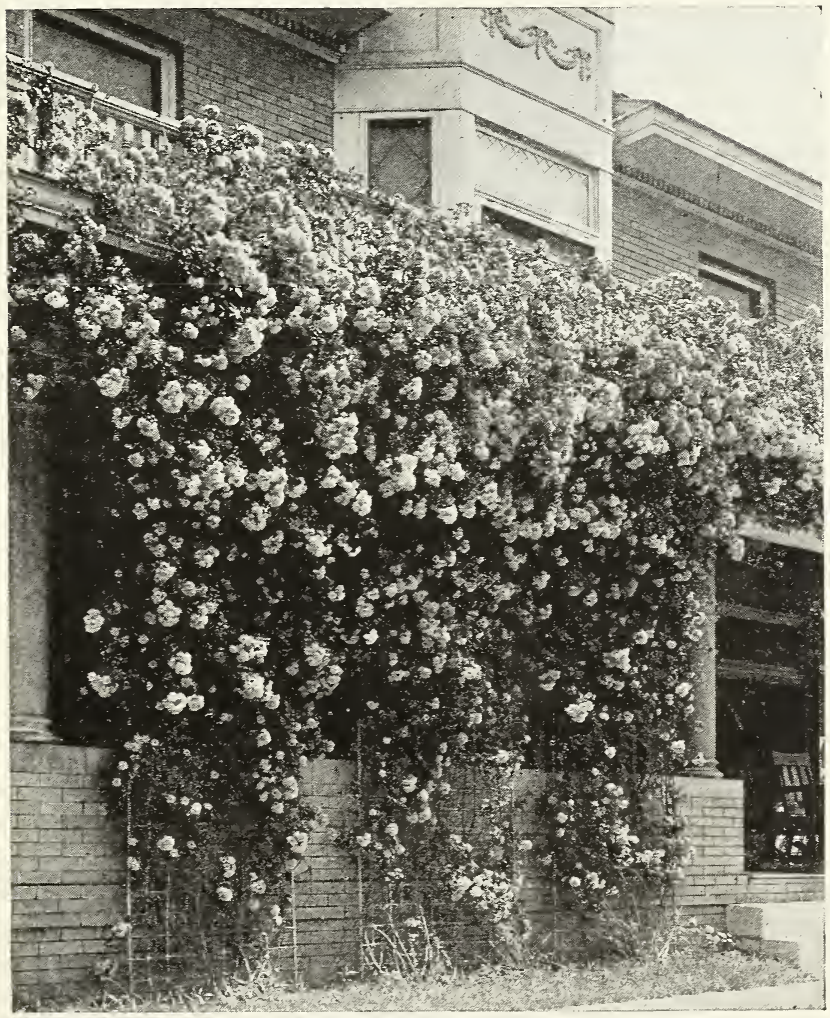

Crimson Rambler
Persian Yellow. Flowers a deep yellow, rather small, but borne in great profusion. Considered one of the best of the yellow roses.

\section{ROSA RUGOSA}

This class of Japanese Roses forms sturdy bushes, 4 to 5 feet high, covered with large, dark green, crinkled glossy foliage, crowned with terminal clusters of 10 to 20 flowers, each 3 inches in diameter. Perfectly hardy. A valuable plant for the hardy border or shrubberies, the large, handsome, scarlet hips being very ornamental all through the autumn and early winter months. It also makes a splendid hedge, its foliage being impervious to the attacks of insects.

Rubra. The typical Rugosa Rose, with large, single, crimson flowers followed by scarlet hips. The foliage is beautifully crinkled.

Alba. Pure white, with typical Rugosa foliage and orange hips.

\section{ROSA RUGOSA HYBRIDS}

Agnes Emíly Carman. Flowers large, semidouble; fine in the bud state; rich, deep crimson. A free and constant bloomer.

Blanc Double de Coubert. Purest paper-white, blooming in clusters of from five to ten flowers; double, very sweet. A strong, rampant grower, having the true Rugosa foliage. Flowers nearly $\tilde{j}$ inches in diameter, produced freely and lasting well.

Charles Frederick Worth. Of extremely strong growth, with attractive deep green foliage, more dense than other varieties. Flowers are crimson with carmine shadings.

Conrad Ferdinand Meyer. Large, cup-shaped, double silvery pink flowers, borne well above handsome Rugosa foliage. Exquisitely perfumed and perfectly hardy.

Hansa. Brilliant red flowers, large in size and handsome in form. The foliage is particularly handsome, being of the true Rugosa character.

Mad. Georges Bruant. Flowers in clusters; semi-double; buds long and pointed, similar to Niphetos in shape; pure white. Remarkably free-flowering, and hardy where the thermometer does not go below zero. It forms a handsome bush for the lawn and yard, as it retains the heavy thorny canes and glossy, leathery leaves of the Rugosa.

New Century. A splendid rose of the Rugosa type, with clear, flesh-pink flowers 3 to 4 inches across, perfectly full and double. Its perfume reminds one of the sweetbriers, and is one of the most constant bloomers.

Nova Zembla. Handsome white flowers and beautiful foliage. Resembles Conrad Ferdinand Meyer in habit of growth. 


\section{Hardy Perennial Plants}

The following collection embraces the most desirable rarieties. Ther are all showr, of easr cultiration and the flowering season is from Mar to Norember. Br a careful selection a continuous displar of flowers mar be had the entire season. If you desire we can make selection for you.

Achillea, The Pearl. Has rery showy heads of pure white, double flowers, on strong erect stems; 2 feet high; blooming constantly.

Anemone, Windflower. One of the most showy of all our autumn-blooming herbaceous plants. Blooms freely from August till cut down by frost. In somewhat moist, rich soil, the plants make a beautiful, hardy border or bed. A slight corering of leares or straw is sufficient protection in most serere winters.

Aquillegia, Columbine. These are plants of elegant habit, distinct in foliage and flowers. The latter form a showy crown well abore the clear-cut leares. All the species like partially shaded, well-drained soil. One of the best plants for rock work, or growing under trees.

Astilbe, Spirea. A beautiful herbaceous plant, blooming in dense spikes of pure white feather-like flowers.

\section{ASTERS}

Michaelmas Daisies. Tall, leafy perennials, blooming in the fall when flowers are scarce.

Alpine Asters. A rich purple.

Italian Starwort. Light blue.

Nevadensis (A. Coccineus). Red, yellow center.

Nevadensis (A. Lilacinus). Lilac.

New England Aster. Bluish-purple.

Bocconia Cordata (Plume Poppy). Stately, growing from 6 to 8 feet high, with large foliage and long spikes of white flowers in August.

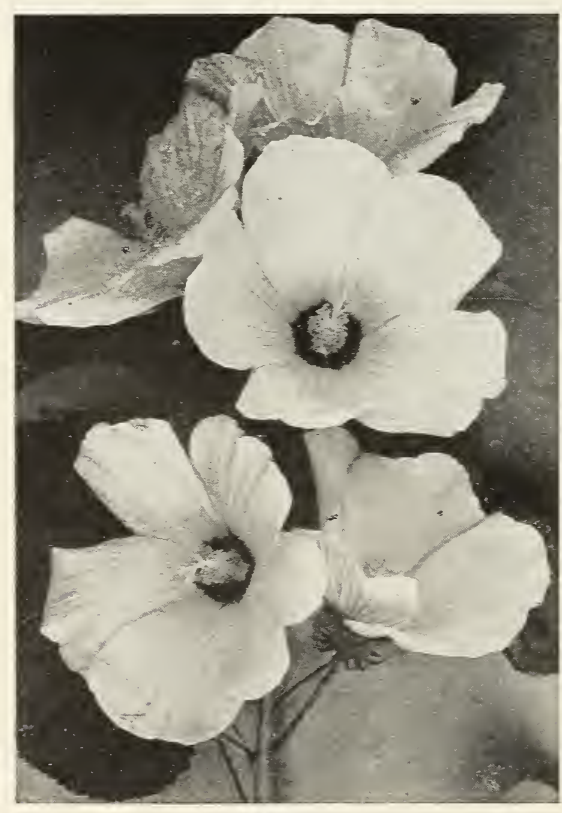

Hibiseus

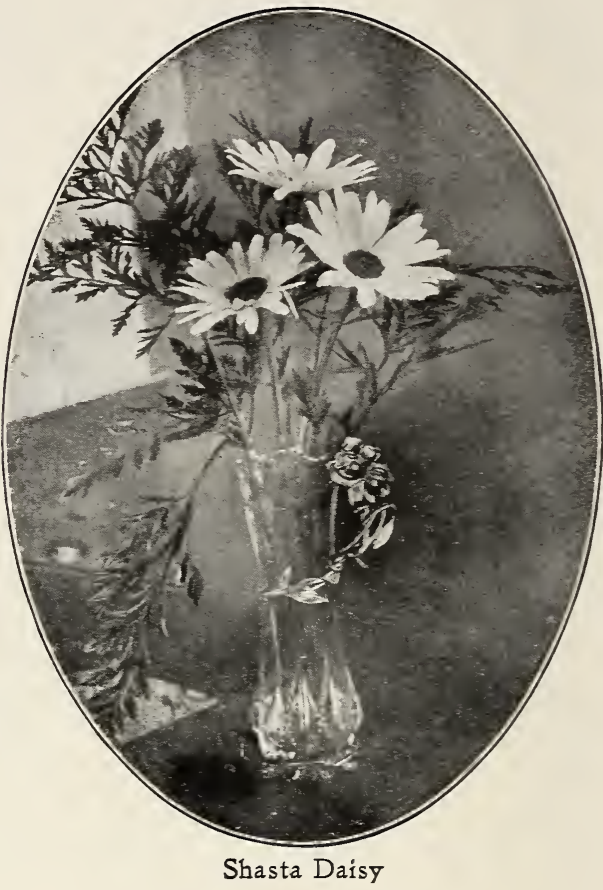

Campanula, Bellflower (Harebell). A lorely hardy little perennial, widely planted erertwhere for its delicate sprays of drooping white bells and their delightful fragrance. The leares are a rich dark green: the plant vigorous, soon forming fine clumps which bloom early in the spring; largely forced in winter.

Coreopsis (Tickseed). Show and raluable free flowering perennials. Produces bright golden-rellow flowers in great profusion the entire season.

Chrysanthemum (Hardy Pompon)). This class of beautiful plants is now unirersally popular for outdoor bedding, and justly so. Ther produce a larish profusion of blooms, giving color, life and beauty to the garden at a time when other plants hare been nipped by frost. They are quite hardr, but it is well to gire a slight corering of leares or manure during winter. Grow from 2 to 3 feet high.

Daisy, Shasta. Large snow-white flowers, 1 inches across; in bloom all summer. i good cut-flower rarietr.

Delphinum (Larkspur). The hardr Larkspurs are one of the most important and most satisfactory plants in the herbaceous garden, and should be planted extensirelr. eren in the smallest garden. Their long spikes of flowers ar produced continuously from June until late in the fall, if the precaution is taken to remore the flower stems before they can produce seed.

Desmodium (Penduliflorum). A beautiful Japanese perennial, with clorer-like foliage and long, pendulous racemes of rosr-purple flowers. The stems are $t$ ieet long, and in early autumn are literally loaded with the flowers. Very hardy and showr, and a fine plant for growing in front of shrubber?.

Dianthus (Sweet William). The old-time farorite, growing $1 \frac{1}{2}$ to 2 feet high, and bearing during Mar and June a profusion of round-topped clusters of flowers of all shades of red and pink to white. 
Dicentra (Bleeding Heart). A hardy perennial with heart-shaped rose colored flowers in drooping spikes. One of the best border plants; perfectly lardy and easily cultivated. Flowers in April or May.

Digitalis (Foxglove). Long bell-shaped flowers, on stems 3 to 4 feet high; white and red; very showy. July to September.

Funkia (Day Lily). A superb autumn flower, having broad, light green leaves, prettily veined, and iong, trumpet-shaped, pure white flowers, that jossess a delightful, though delicate fragrance.

Gaillardia Grandiflora (Blanket Flower). A showy plant with dense tufts of drooping leaves and flower stems, producing daisy-like blossoms 2 to 3 inches across, of gorgeous colors; blooms in the most wonderful profusion from $J$ une to November.

Hibiscus (Militaris). Strong growing, 4 to 6 feet high, with white, blush or pale rose flowers, with purple eye, blooming in August and September.

Hibiscus (Crimson Eye). Immense flowers of purest white, with large centers of velvety crimson. Blooms very profusely, the plants being covered all summer with a wealth of most beautiful, attractive flowers.

Hollyhocks. Few hardy plants combine as many good qualities as the Hollyhock. For planting in rows or groups on the lawn, or for interspersing among shrubbery, they are invaluable. The flowers form perfect rosettes of the most lovely shades of yellow, crimson, rose, pink, orange, white, etc. The Hollyhock requires a rich, deep soil, well drained; will repay in quality and elegance of bloom any extra care. Protection in winter will be beneficial.

Hyacinthus (Candicans). A magnificent yuccalike plant producing in July and August, a flower

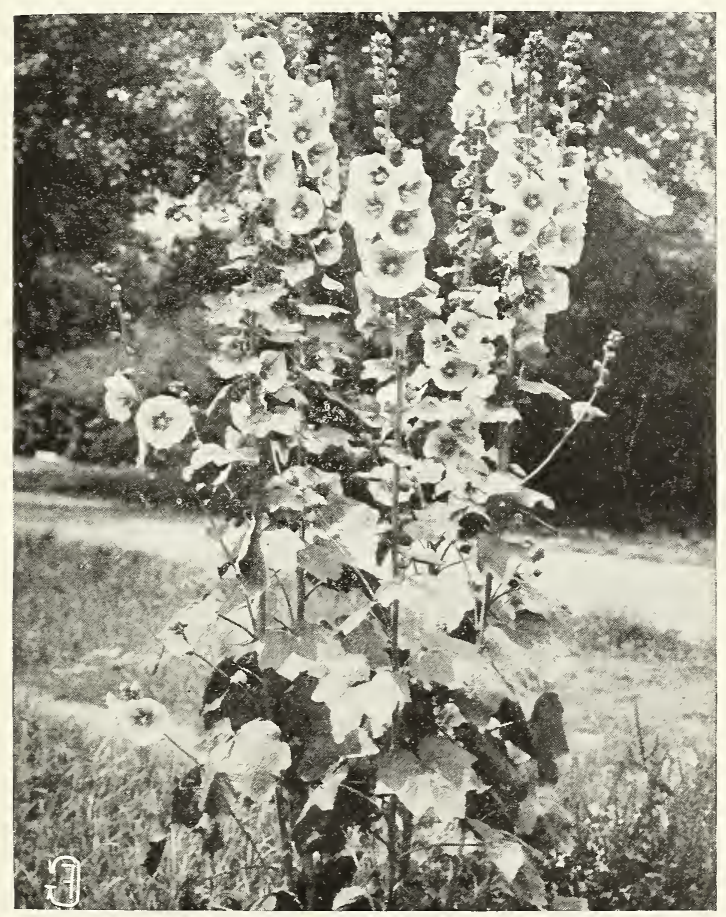

Hollyhocks

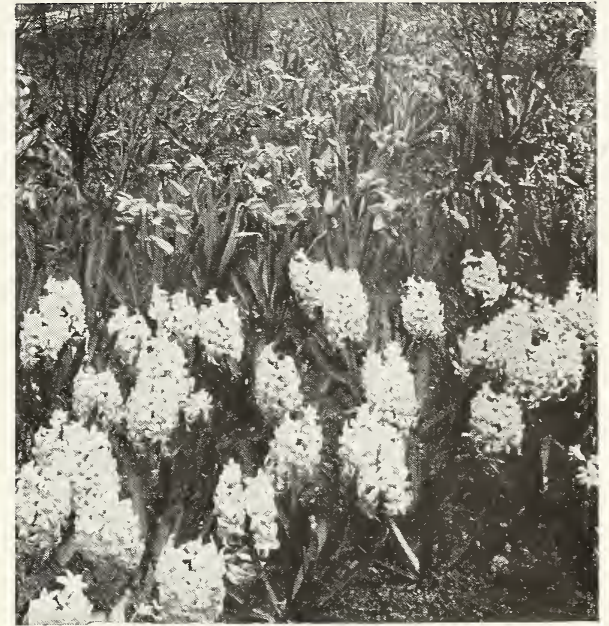

Hyacinths

stem 3 to 4 feet high, covered with from 20 to 30 pure white, pendent, bell-shaped flowers.

Iberis Sempervirens (Candytuft). Of spreading habit; flowers pure white, covering the plant with bloom. One of the finest border plants, beautiful with flowers very early in spring; good for cutting.

Platycodon (Chinese Bell-Flower). A valuable perennial, forming a dense branching bush of upright habit, 1 to 2 feet high, with neat foliage. From the middle of July until late September it bears a constant succession of handsome, large, bell-shaped, deep blue flowers. Succeeds well in any ordinary soil.

Rudbeckía (Golden Glow). A distinct, tall-growing, hardy perennial, from 6 to 7 feet high. Foliage deeply cut, handsome bright green; flowers very double, rich golden-yellow; 2 to 3 inches in diameter; borne on long, smooth stems, forming for the tall plant a solid head of bloom.

Stokesia Cyanea. A grand large flowered, hardy perennial, growing 18 to 24 inches high, and covered with centaurea-like flowers of a beautiful lavender blue shade, and often 4 to 5 inches across. Of earliest possible culture, flourishing wherever given an open, sunny exposure. As a single specimen plant, used in mixed borders or in large masses by itself, it is equally valuable, and by its use, some very effective planting may be worked out. Blooms from July to October continuously.

Tritoma (Red-Hot Poker). These are tall and striking plants of much beauty when well placed and properly grown. The great spikes of flowers sent up from the center of a broad circle of green leaves, have quite a rich and tropical apparance. Give some protection in cold climates. Bloom from July to September.

Yucca, Filamentosa (Adam's Needle). Tery conspicuous plant. The flower stalks 3 and 4 feet high are covered with large, whitish, bell-shaped flowers. 


\section{Hardy Bulbs for Fall Planting}

Crocus. These are delicate and tasteful in form and varied and gay in color. Until the flowering of the Hyacinth, and through the most changeable and unpleasant of spring weather, the garden depends almost alone upon the Crocus for its brightness. Plant the bulbs in autumn about 3 inches apart and cover with $\mathbf{2}$ inches of soil. Cover in fall with a little straw or coarse manure to keep the bulbs from being thrown out by frost.

Hyacinths. Among all the bulbs used for winter flowers, the Hyacinth stands foremost. Flowers may be produced by placing the bulbs in a glass filled with water or placed in pots or boxes in soil; colors, blue, red, white, with various shades.

Jonquils. Sweet-scented, yellow. It is one of the early blooming bulbs.

\section{LILIES. Lilium}

No class of plants capable of being cultivated out-ofdoors possesses so many charms; rich and varied in color, stately and handsome in habit, profuse in variety, and of delicious fragrance, they stand prominently out from all the other hardy plants. Lilies thrive best in a dry, rich soil, where water will not stand in the winter. After planting they require very little care, and should not be disturbed for several years. Established plants bloom more freely than if taken up annually. Plant in groups of five or six, or in large beds.

Lilium Auratum (Gold Band or Lily of Japan). Flowers very large, delicate ivory-white, thickly dotted with rich, chocolate-crimson spots. A bright golden band runs through the center of each petal. The finest of all lilies.

Lilium Harrisii (Bermuda Easter Lily). Flowers large, trumpet-shaped, pure waxen-white, gracefully formed and delightfully fragrant. The ease with which it can be forced into flower in winter has made it wonderfully popular.

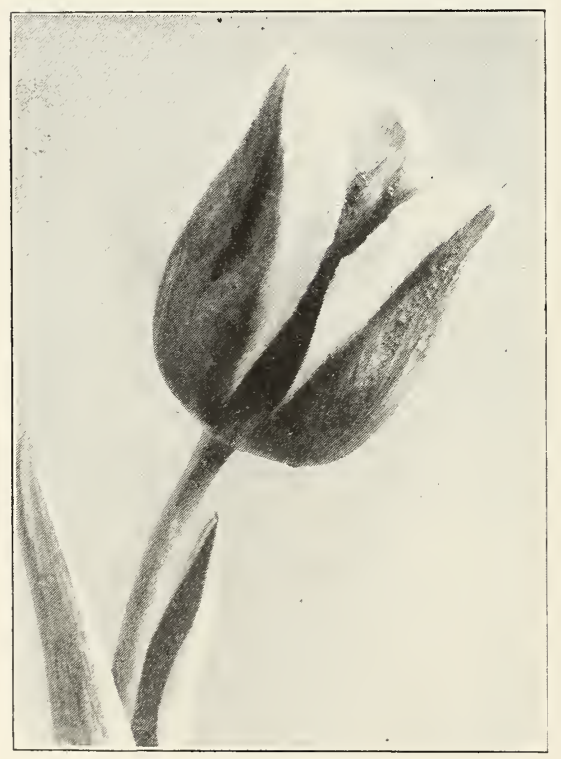

Darwin Tulip

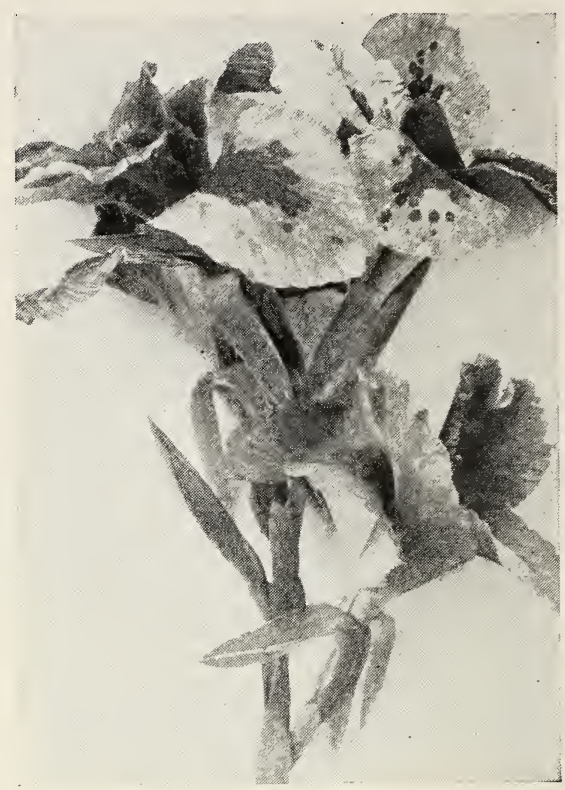

Cannas

Lilium Longiflorum. Large, snow-white, trumpet-shaped; very fragrant.

Lilium Melpomene. Flowers large and abundant; rich bloom-crimson; heavily spotted.

Lilium Tigrinum (Double Tiger Lily). Orangescarlet, with dark spots.

Lilium Speciosum. White, shaded with rose, spotted red.

Lilium Speciosum Album. White, with a slight rose tint on the ends of the petals.

\section{NARCISSUS}

Some varieties bloom as early as the Crocus. The flowers assume many forms and present many charming combinations of white, gold, primrose, orange, sulphur and pure yellow. Some are quite fragrant; all are very hardy, except the clustered Polyanthus. Double and single.

\section{TULIPS}

These are the most glowingly brilliant and effective of all the early spring flowers. Plant them thickly and lavishly in the fall and they will reward you with abundant cheer during the cold, dull months of early spring. Colors many. Double and single.

\section{DARWIN TULIPS}

\section{"The Tulip Aristocrats"}

The flowers of this superb class have well been called "The Tulip Aristocrats." 'The remarkably brilliant coloring and splendid substance of their distinctly globular or cup-shaped flowers of large size, their long, strong stems and robust growth of plant, make them unsurpassed for May blooming in the garden. Darwins are not only very desirable for out-door budding and last a long time after cutting, but have an advantage over other classes of tulips in that they may be forced in pots provided it is done slowly. Another remarkable characteristic of Darwins is that the color inside the flower is just as bright and sometimes even brighter than the outside. 
There are no yellow Darwins. The varieties we offer have been selected from a very large list after careful trials, and we believe they are the most satisfactory that are obtainable.

Clara Butt. Delicate salmon-pink. One of the most popular; good bedder, adapted also to forcing.

Pride of Haarlem. Deep carmine rose, tinted lilac; very large size and unsurpassed for its class; used for forcing and most excellent for bedding.

The Sultan. Tery dark maroon, almost black. The darkest tulip we list.

Gretchen. Silvery pale rose, flushed white inside soft pink with white center marked blue, a very beautiful flower of delicate color. Height 24 inches.

La Candeur (White Queen). Lovely soft white, slightly tinged blush, anthers black; a beautiful large globular erect flower

Darwin Mixed. Very tall, self-colored, all shades from pale blush to darkest maroon, almost black.

\section{DAHLIAS}

These showy and pretty flowers are becoming very popular and justly so. The Dahlia is one of the showiest of all fall flowers, commencing to flower in July, they are a perfect bloom until stopped by frost. Flowers are most perfect and of beautiful form. Dahlias are divided in classes as follows: Cactus, Decorative, Show, Fancy, Pompon, Single, Collarette and Seedling; each class is comprised of a number of different varieties.

\section{Cactus Dahlias}

Countess of Lonsdale. A peculiar but pleasing blending of salmon-pink and amber, a color difficult to describe. This is the dahlia for the millions. Flowers freely under all conditions.

Gen. Buller. Cardinal-red, each petal tipped with white.

J. H. Jackson. Brilliant crimson-maroon; very free.

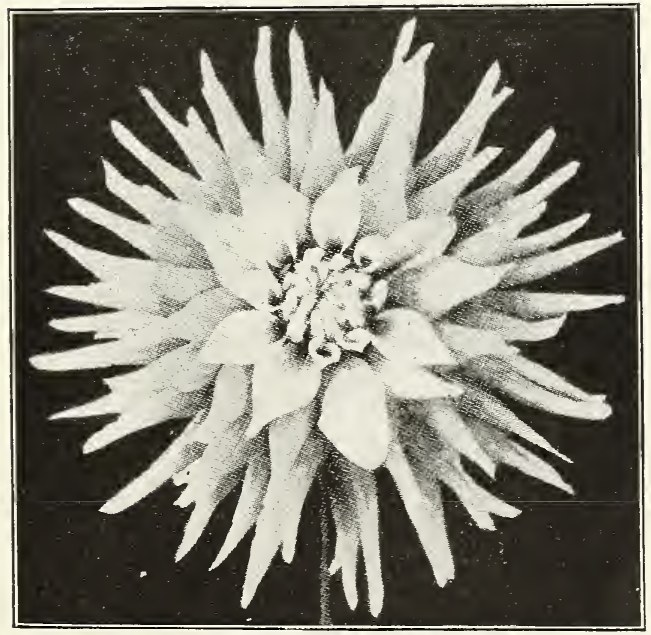

Dahlia
Kriemhilde. A most popular cut flower variety; perfect flowers on long stems; color a brilliant pink, gradually shading to white at the center.

Mrs. H. J. Jones. Tery large, perfect, rich, bright scarlet with cream-colored edge; occasionally comes self-colored.

\section{Decorative Dahlias}

A. D. Livoni. Beautiful clear pink, of perfect form and very free.

Catherine Duer. Irridescent red; a favorite for cutting.

Grand Duke Alexis. Large, massive flowers, ivory-white, with a faint tinge of rose at the extremities of the petals.

Jack Rose. Brilliant crimson red, rich and glowing, similar in shade to the popular "Jack" rose, which suggested its name. The habit of the plant is perfect for garden decoration, while its stiff stems, holding the large flowers erect, secure for it a foremost place as a high-colored cut flower.

Souevnir de Gustave Doazon. A decorative rariety of mammoth proportions, which under ordinary cultivation will produce flowers 6 inches across, and can be grown to measure full 9 inches. It is of free growth, remarkably profuse-flowering, and pure red in color.

Queen Wilhelmina. Immense, fluffy flower of pure white with yellow center.

\section{Zuír. Deep maroon with black shadings.}

\section{Bulbs and Tubers}

\section{FOR SPRING PLANTING}

Amaryllis. Velvety crimson flowers early in summer. Planted out in May in rich ground. The roots are stored like Dahlias during winter.

Caladium Espulentum (Elephant's Ear). For obtaining tropical effects in lawn and garden planting, this beautiful plant takes a prominent place. Grows well in any ordinary soil, but should have plenty of water and good rich soil to obtain best results. Bulbs must be taken up in fall and kept in a dry, warm place.

Cannas. Very attractive plants, with large green leaves, often shaded with red and crimson. Cannas are the most satisfactory plants one can use for producing a gorgeous display of brilliantly colored flowers all summer long; they bloom until frost.

Gladioli. The Gladioli is the most attractive of all the summer flowering bulbs and deserves a place in every garden, as it is sure to flower and do well with little care. Flowers are of most every desirable color. By cutting the spikes when two or three of the lower flowers are open and placing them in water, the entire spike will open beautifully. Plant bulbs in April or May for early, and late in June for fall blooming.

Tuberoses. One of the best known and most easily grown summer flowering bulbs. Easily recognized by its exquisite fragrance and beautiful flower spikes, which are borne on long stems, making it an admirable cut flower for house decoration. 


\section{Spirea Anthony Waterer}

(See Page 41)

A recent improvement over the $\mathbf{S}$. Bumalda. Forms a low bushy hedge from 2 to $2 \frac{1}{2}$ feet high and is covered all summer with a small flat head of bright pink flowers. A new scarce dwarf shrub of high merit, absolutely hardy and especially adapted for hedge purposes. It furnishes not only a rich green foliage, but has an almost perpetual bloom of beautiful flowers. Plant in April, about 18 inches apart in row. The first period of blooming is from the middle of June until the first of August. Immediately after these flowers disappear, shear back to a uniform height. The next crop appears about the first of September and lasts until a hard freeze. Shear back again in late fall or early spring.

\section{Catalpa Bungeii or Umbrella Tree}

(See Page 29)

Grafted on stem 6 to 8 feet high, it makes an umbrella-shaped top without pruning. Perfectly hardy, and flourishes in almost all soils and climates. Leaves large, glossy, heartshaped, deep green; lie like shingles on a roof; always making a symmetrical head. One of the most unique trees; desirable for lawn and park planting. Plant in April. Plant trees 6 to 8 feet in height, and the best specimens only. Wrap bodies of all ornamental trees the first season to guard against sun-scald.

\section{Testimonials}

Horse Creek, Wyo.

Harrison Nursery Co., York, Nebr.

Gentlemen: Trees arrived April 26th in fine shape. Enclosed please find check for amount due. Now in regard to your trees, will say that I am highly pleased; best packed for shipment and best sized trees for money that I ever received, and if you wish you may use the above letter and $\mathrm{my}$ name as a testimonial in Wyoming or anywhere else. I am, Very sincerely yours,

Charles Smith.

Harrisen Nursery Co., York, Neb.

Ravenna, Nebr.

Gentlemen: Enclosed please find my check for $\$ 17.20$ as per invoice of April 17th. The trees came in good order and I think I have the best lot of nursery stock I ever put into the ground. I thank you for the care and the pains you took in putting up the two orders I received this spring.

Yours truly,

C. A. Pierson.

North Loup, Nebr.

Harrison Nursery Co., York, Neb.

Gentlemen: Some days ago I received the stock ordered from your saleswoman last fall. I found the plants more than satisfactory and now after they have been set out some seven or eight days they look fine, and I do not believe that I will lose a single plant. I found these to be the best rooted plants that I ever saw and they came out of the wrapping just as fresh as could be.

Wishing you much success, I am, Truly yours,
D. S. Bohr.
Harrison Nursery Co., York, Nebr.

Wray, Colo.

Gentlemen: I am pleased to say that the stock from your nursery, used by the irrigation plants which I had installed along the Burlington Railroad in eastern Colorado, is giving perfect satisfaction. Yours truly, James Cheney.

Harrison Nursery Co., York, Nebr.

Canon City, Colo.

Gentlemen: Trees arrived Monday. Had them inspected the next morning. Nothing condemned except two pear trees. The inspector said he never saw such a superior lot of trees. Yours truly,

C. C. Smith.

Harrison Nursery Co., York, Nebr.

Orleans, Nebr.

Gentlemen: Enclosed find draft in payment of trees received from you. We found same to be a very fine bunch of roots and if they do not grow it surely won't be your fault. If you wish to refer to me in regard to the quality of stock you send out I will be pleased to recommend your stock. Yours respectfully, R. R. Bodien.

Stockham, Nebr.

Harrison Nursery Co., York, Nebr.

Gentlemen: The Golden Beauty crab I purchased of you this year bore fourteen apples. I can heartily recommend this crab apple to anyone. The other trees I purchased of you have all done fine and am well pleased with your stock. Yours truly, 


\section{Spraying Calendar}

This spraying calendar is prepared for the purpose of serving our customers as a guide to the most effective ways of controlling insects and diseases of plants. When San Jose scale is present, there should be an application of lime-sulphur just before the buds begin to swell in the spring. All applications before and immediately following the bloom are the most important. Seasonal conditions may warrant the omission of some of the later applications.

\begin{tabular}{|c|c|c|c|c|}
\hline PLANTS & Ist Application & 2d Application & Bd Application & 4th Applieation \\
\hline $\begin{array}{l}\text { Apple } \\
\text { Codling moth, } \\
\text { curculio, aphis, } \\
\text { scab, blotch, bit- } \\
\text { ter rot. }\end{array}$ & $\begin{array}{l}\text { When blos som } \\
\text { buds show pink. } \\
\text { Lead arsenate with } \\
\text { lime-sulphur. Add } \\
\text { nicotine sulphate if } \\
\text { aphis are present. }\end{array}$ & $\begin{array}{l}\text { Calyx cup spray, } \\
\text { made as soon as all } \\
\text { petals have dropped } \\
\text { but b e for e calyx } \\
\text { closes. Lead arse- } \\
\text { nate with bordeaux } \\
\text { mixture or lime-sul- } \\
\text { phur. }\end{array}$ & $\begin{array}{l}\text { Repeat with same } \\
\text { materials } 7 \text { to } 10 \\
\text { days later. }\end{array}$ & $\begin{array}{l}\text { In July, if blotch } \\
\text { or bitter rot appear, } \\
\text { use bordeaux mix- } \\
\text { ture with arsenate } \\
\text { of lead. }\end{array}$ \\
\hline $\begin{array}{l}\text { Cherry } \\
\text { Aphis, Brown } \\
\text { rot, curculip, } \\
\text { slug, black knot. }\end{array}$ & $\begin{array}{l}\text { About } 10 \text { days } \\
\text { after petals have } \\
\text { dropped or when the } \\
\text { shucks are dropping } \\
\text { from young fruit, } \\
\text { apply arsenate of } \\
\text { lead. }\end{array}$ & $\begin{array}{l}\text { About } 10 \text { da y s } \\
\text { later apply lead ar- } \\
\text { senate with self- } \\
\text { boiled lime-sulphur. } \\
\text { If aphis are present } \\
\text { also, add nicotine } \\
\text { sulphate. }\end{array}$ & $\begin{array}{l}\text { Should slugs ap- } \\
\text { pear on the leaves, } \\
\text { apply arsenate of } \\
\text { lead. }\end{array}$ & \\
\hline $\begin{array}{l}\text { Currant } \\
\text { Mildew, worms } \\
\text { Gooseberry }\end{array}$ & $\begin{array}{l}\text { As soon as worms } \\
\text { are found on lower } \\
\text { and inner leaves, } \\
\text { use lead arsenate. }\end{array}$ & $\begin{array}{l}\text { If they reappear, } \\
\text { use bordeaux mix- } \\
\text { ture and lead arse- } \\
\text { nate. }\end{array}$ & $\begin{array}{l}\text { If worms bother } \\
\text { as fruit is ripening } \\
\text { use pyrethrum or } \\
\text { hellebore. }\end{array}$ & \\
\hline $\begin{array}{l}\text { Grape } \\
\text { Mildew, black } \\
\text { rot, leaf hopper, } \\
\text { root worm, flea } \\
\text { beetle. }\end{array}$ & $\begin{array}{l}\text { When first leaves } \\
\text { are half grown, use } \\
\text { bordeaux mixture } \\
\text { and lead arsenate. }\end{array}$ & $\begin{array}{l}\text { As soon as the } \\
\text { fruit has set, re- } \\
\text { peat. }\end{array}$ & $\begin{array}{l}10 \text { to } 14 \text { days later } \\
\text { repeat if necessary. }\end{array}$ & $\begin{array}{l}\text { Do not use lime- } \\
\text { sulphur on grapes } \\
\text { when in leaf. }\end{array}$ \\
\hline $\begin{array}{l}\text { Peach } \\
\text { Brown rot, } \\
\text { curculio. }\end{array}$ & $\begin{array}{l}\text { When husks are } \\
\text { shedding from the } \\
\text { young fruits use ar- } \\
\text { senate of lead. }\end{array}$ & $\begin{array}{l}\text { Ten days later } \\
\text { use self-boiled lime- } \\
\text { sulphur with lead } \\
\text { arsenate. }\end{array}$ & $\begin{array}{l}\text { Three or four } \\
\text { weeks later use } \\
\text { self boiled lime-sul- } \\
\text { phur. }\end{array}$ & $\begin{array}{l}\text { Repeat in } 2 \text { or } 3 \\
\text { weeks if necessary. }\end{array}$ \\
\hline $\begin{array}{l}\text { Pear } \\
\text { S c a b, codling } \\
\text { moth, slugs, psylla. }\end{array}$ & $\begin{array}{l}\text { Wh e n blossoms } \\
\text { are in "cluster bud" } \\
\text { stage, apply bor- } \\
\text { deaux mixture with } \\
\text { nicotine sulphate. }\end{array}$ & $\begin{array}{l}\text { Calyx cup spray. } \\
\text { Use bordeaux mix- } \\
\text { ture with lead arse- } \\
\text { nate and nicotine } \\
\text { sulphate. }\end{array}$ & $\begin{array}{l}7 \text { to } 10 \text { days later } \\
\text { apply arsenate of } \\
\text { lead with nicotine } \\
\text { sulphate. }\end{array}$ & $\begin{array}{l}\text { Later applications } \\
\text { may be unnecessary } \\
\text { unless slugs appear. } \\
\text { Then use lead arse- } \\
\text { nate. }\end{array}$ \\
\hline $\begin{array}{l}\text { Plum } \\
\text { Brown rot, } \\
\text { curculio. }\end{array}$ & $\begin{array}{l}\text { Bordeaux mixture } \\
\text { with lead arsenate } \\
\text { when buds are } \\
\text { swelling. }\end{array}$ & $\begin{array}{l}\text { When shucks drop } \\
\text { from young fruits } \\
\text { apply self - boiled } \\
\text { lime-sulphur with } \\
\text { lead arsenate. }\end{array}$ & Repeat in 2 weeks. & $\begin{array}{l}\text { Should rot appear } \\
\text { later, repeat. }\end{array}$ \\
\hline $\begin{array}{l}\text { Blackberry } \\
\text { Raspberry } \\
\text { Anthracnose, rust. }\end{array}$ & $\begin{array}{l}\text { Cut out dead and } \\
\text { diseased canes be- } \\
\text { fore buds open and } \\
\text { apply strong bor- } \\
\text { dea.ix mixture. }\end{array}$ & $\begin{array}{l}\text { When majority of } \\
\text { young canes are a } \\
\text { foot high, apply } \\
\text { Dordeaux mixlure. }\end{array}$ & $\begin{array}{l}\text { As soon is fruit s } \\
\text { off, repeat. }\end{array}$ & $\begin{array}{l}\text { If red rust ap- } \\
\text { pears in the black- } \\
\text { bem.es the entire } \\
\text { stool affected should } \\
\text { be dug up and } \\
\text { burned. }\end{array}$ \\
\hline $\begin{array}{l}\text { Roses } \\
\text { Aphis, s l u g s, } \\
\text { leaf spot. }\end{array}$ & $\begin{array}{l}\text { When aphis ap- } \\
\text { pear, use nicotine } \\
\text { sulphate. }\end{array}$ & $\begin{array}{l}\text { Use lead arsenate } \\
\text { When slugs appear } \\
\text { on the leaves. }\end{array}$ & $\begin{array}{l}\text { Early summer ap- } \\
\text { plications of bor- } \\
\text { deaux mixture will } \\
\text { control black spots } \\
\text { on leaves. Cut out } \\
\text { diseased portion in } \\
\text { fall, b ur n, then } \\
\text { spray again with } \\
\text { bordeaux mixture. }\end{array}$ & $\begin{array}{l}\text { For powdery mil- } \\
\text { dew apply lime-sul- } \\
\text { phur or potassium } \\
\text { sulphid. }\end{array}$ \\
\hline
\end{tabular}




\section{INDEX}

\begin{tabular}{|c|c|}
\hline \multirow{2}{*}{\multicolumn{2}{|c|}{ Abies . }} \\
\hline & \\
\hline Acer ...... & \\
\hline Achillea .... & \\
\hline Adam's Needle & \\
\hline Aesculus ................ & \\
\hline Ailanthus & \\
\hline A kebia ......... & \\
\hline Alder ... & \\
\hline Almond & \\
\hline Alnus .... & \\
\hline Althea & \\
\hline Amaryllis ........ & \\
\hline American Iry & \\
\hline Ampelopsis ... & 4 \\
\hline Amygdalus & \\
\hline Anemone ... & 5 \\
\hline Appl & $\tau-1$ \\
\hline Apples, Crab & 1 \\
\hline A pricots ............ & 1 \\
\hline Aquilegia ...... & 5 \\
\hline Arbor Vitae ... & 2 \\
\hline Asparagus .... & \\
\hline Ash ........................ & $2 \gamma-2$ \\
\hline Ashberry .... & \\
\hline Astilbe ... & \\
\hline ris & \\
\hline
\end{tabular}

\section{B}

Balsam Fir

Balm of Gilead

Barberry

29

Bechtel's Flowering Crab .... $\quad 29$

Beech

Bellflower ............................... 56

Berberis ................................36-44

Betula ...................................28, 33

Bignonia .................................. 43

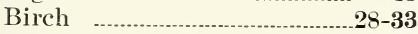

Bitter Sweet ............................ 43

Blackberries …........................ 20

Black Locust ......................... $\quad 30$

Blanket Flower ....................... 57

Bladder Senna ...................... $3 \gamma$

Bleeding Heart .....................

Boston Iry ........................... 43

Box Elder ............................ 30

Boxwood ............................ 26

Buckthorn _........................... $\quad \mathbf{3 6}$

Buckere

Bulbs and Tubers for Fall Planting

Bulbs and Tubers for Spring Planting

Button Bush

Butternut

Butterfly Bush

\section{C}

Caladium

Calycanthus

California Privet

Campanula

Candytuft

Cannas

28

\begin{tabular}{|c|c|c|c|}
\hline & Page & & Page \\
\hline Caragana & 37 & Fraxinus & 27 \\
\hline Castanea & 28 & Fringe Tree & 39 \\
\hline Catalpa. & 29,60 & Fruit Department & $7-21$ \\
\hline Celastrus ........ & 43 & Funkia ..................... & \\
\hline lanthus & 37 & & \\
\hline ................ & 29 & & \\
\hline & 28 & Gaillardia & \\
\hline & 32 & $\mathrm{Gi}$ & \\
\hline , & 14,28 & olus & \\
\hline & 24,28 & schia & $29-4$ \\
\hline hus & 39 & Flower & 39 \\
\hline Arbor & 26 & n Bell.. & \\
\hline Bell Flow & 57 & en Glow & \\
\hline ee Lilac ................ & 39 & eberries & \\
\hline $\mathrm{m}$ & 56 & & $.17-18$ \\
\hline Alematis & 43 & 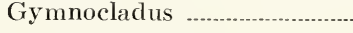 & \\
\hline
\end{tabular}

\section{$\mathrm{H}$}

Columbine .......................... 50

Colutea ................................... 37

Compass Cherry-Plum ........ 14

Cornus _ 29,37

Corchorus _.............................. 39

Coral Berry ............................. 41

Coreopsis …......................... 56

Crab ....................... 11,29

Crataegus ................................ 33

Cranberry ….......................... 41

Crimson Eye ............................ 57

Crocus $\quad 58$

Cucumber Tree ......................... 30

Currants .............................22, 37

Crdonia

\section{D}

Dahlias

Day Lily

Deciduous Hedge .................. 44

Dewberries .......................... 20

Desmodium ….......................37-56

Deutzia ............................... $3 \tau$

Delphinum ….......................... 56

Dicentra _................................. 57

Diervilla _................................ 42

Distance to plant .................... 6

Diospyros _......................... 31

Dioscorea …....................... 43

Dianthos _................................. 56

Digitalis ............ 57

Dogwood ............................................

Dwarf Bearded Irises ......... $\$ 9$

Elder

\section{E}

Eleagnus

38

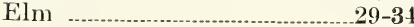

59 Elephant's Ear _........... 59

37 Evergreens …..........................26-27

24. Exochorda …...................... 38

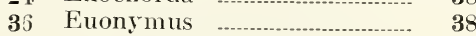

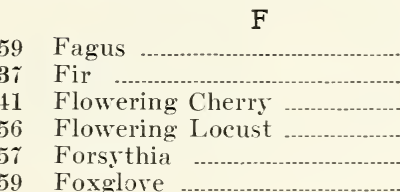

Handy Hints on Spraying... 62

Hackberry ............................... 29

Halesia $\quad 39$

Harebell ............................. 56

Hawthorne .............................. 33

Hedge Plants ........................ 44

Herbaceous Paeonies ............. 45

Horse Chestnut ...................... . 28

Hibiscus ……............................. 57

High Bush Cranberry ......... 41

Honey Locust ........................ 44

Honeysuckle ............................39, 44

Hollyhocks ............................ 57

Hydrangea ............................... 39

Hyacinthus …....................... 57

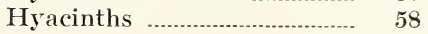

\section{I}

Iberis

Introductory ............................ 3

Information, General ........... 4

Instructions for Planting....

$5,6,25,26,50$

Iris _............................................. 49

Iris, Germanica ..................... 47

\section{$J$}

Japanese Paeonies ............... 47

Japanese Silver Thorn ........ 38

Japan Quince .....................39, 4.

Jonquils .................................... 58

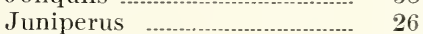

Juniper ........... 26

Judas Tree

K

Kudzu Vine 4

Kentucky Coffee Tree ........ 29

Kerria _............. 39

L

Lantana _................................ 41

28 Larch

26 Larkspur

29 Larix 29

39 Linden .................................... 34

57 Lilies
Hardy Vines ........................... 43

35 Lilac ….................................. 39,40 


\section{INDEX-Continued}

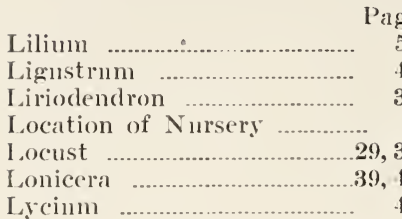

\section{M}

Machura

Magnolia

Maple

Maiden Hair

Malionia

Maehuris

Madeira Vine

Matrimony Vine

Meadow Sweet

Michaelmas Daisy

Mock Orange

Iorus

Mountain I sh

Nulberries

Page

58 Plums

Platanus 33

3

29,30

39,4

tit

N

Narcissis

Nettle Tree

Norway Poplar

Number of 'Trees to Acre.

Nut 'Trees

\section{$\mathrm{O}$}

Officinalis (Old-Fashioned Type) ……..................... 47

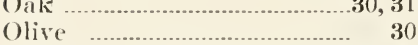

Ornamental Shrubs................35-43

Ornamental Department .... 25

Osage Orange

\section{$\mathrm{P}$}

Pyrus Japonica

Paconies

Pears

Peaches

Pea 'Tree

Pearl Bush

Pecans

Persimmon

Periploca

Perennials

Philadelphus

Phlox

Pie Plant

Pine

Pinus

Pieea
$23,30,31$

30-31

$23,30,31$

58

29

32

21

\%.

(4)

4

(1)

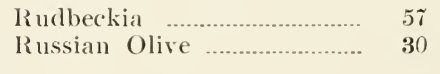

12

16, 12

$3 \pi$

$3 \pi$

$2+$

21

41

$56,5 \tilde{i}$

12

49

24

26

26 lane Tre

Platyeodon

Poplar

Populus

Poker Plant

Privet

Prunus

Prorus

Pueraria Thunbergiana

\section{Q}

Quince

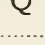

Quercus

\section{R}

Raspberries

Red Bud

Rhubarb

Rhaminus

Rhus

Ribes

Rocky Mountain Cherry

Robinia

Rosa Rugosa

Rose of Sharon

Rhodotypos

Roses

- Climbing

“ Hybrid Perpetua

" Miscellaneous

" Moss

" Polyantha

" Rambler

" Tea

" Trailing

". 'Tree

$S$

Salisburia.

Salix

Sambucus

Seedling Trees

Shasta Dalisy

Shrubs

Siberian Pea Tree

Silk Vine.

Silver Bell

Silver 'Thorn

Single Lilacs

Smoke Tree

Snowball
Page

$.14,15,31$

33

33

56

57

31, 32

..31, 32

57

41

31

29-31

41

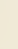

23

30,31

R

$\begin{array}{ll}21 \\ \ldots 2 \ldots \ldots \ldots \ldots . . . . & 32\end{array}$

24

39. 41

41
37

14

30,35

55

35

41

50-56

52

51,52

55

$54,5.5$

54

52-53

53.54

54

54

33, 34

35

33

56

5-42

$3 \tau$

44

39

38
10

39

41
Page

Snowberry .............................

Sorbus ..................................... $\quad 30$

Spirea .....................................t1-60

Spruee ....................................26, 27

Starwort ................................... 56

Stokesia ..................................... 5

Strawberries _..........................19, 20

Strawberry Tree .................... 35

"Sudden Sawlog" .................. 32

Sumach …................................ 41

Sweet Chestnut .......................24, 39

Sweet Pea Shrub ................. 37

Sweet-Scented Shrub ............. 37

Sweet William ......................... 56

Siberian Irises ............................. 49

Spraying Calendar .................. 61

Sycamore ….............................. 33

Symphoricarpus ..................... 41

Syringa .............................. 40,42

\section{$\mathrm{T}$}

Tamarix ................................... 42

Teeoma ……......................... 43

Thorn ....................................... 33

Thuya _............................. 26

Tickseed .................................. 56

Tilia 29

Tree of Heaven ...................... $2 \tilde{\imath}$

Tritoma ……........................... ริ

Trumpet Creeper .................... 13

Tuberoses …………................ 59

Tulips ................................... 59

Tulip Tree ............................... 33

\section{U}

[lmus _.....................................29, 34

Lpright Deciduous Trees ...2 2 i-3.5

\section{V}

Viburnum …….....................

Vines ....................................43, 14

Virginia Creeper ..................... 43

Virgin's Bower .......................43, 4

Walnuts ….....................24, 33

Wayfaring Tree ................... 41

Weeping Trees .....................33, 34

Weigelia ................................. 42

Wrillow ...................................33, 34

Windflower ….......................... 56

Wistaria ......................................

Woodbine .................................. 43

White Kerria ............................ 41

Yucca .................................

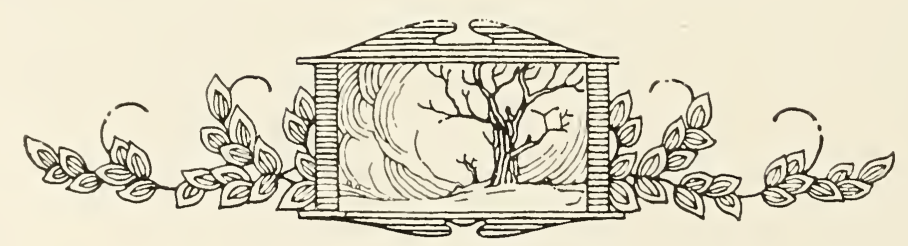





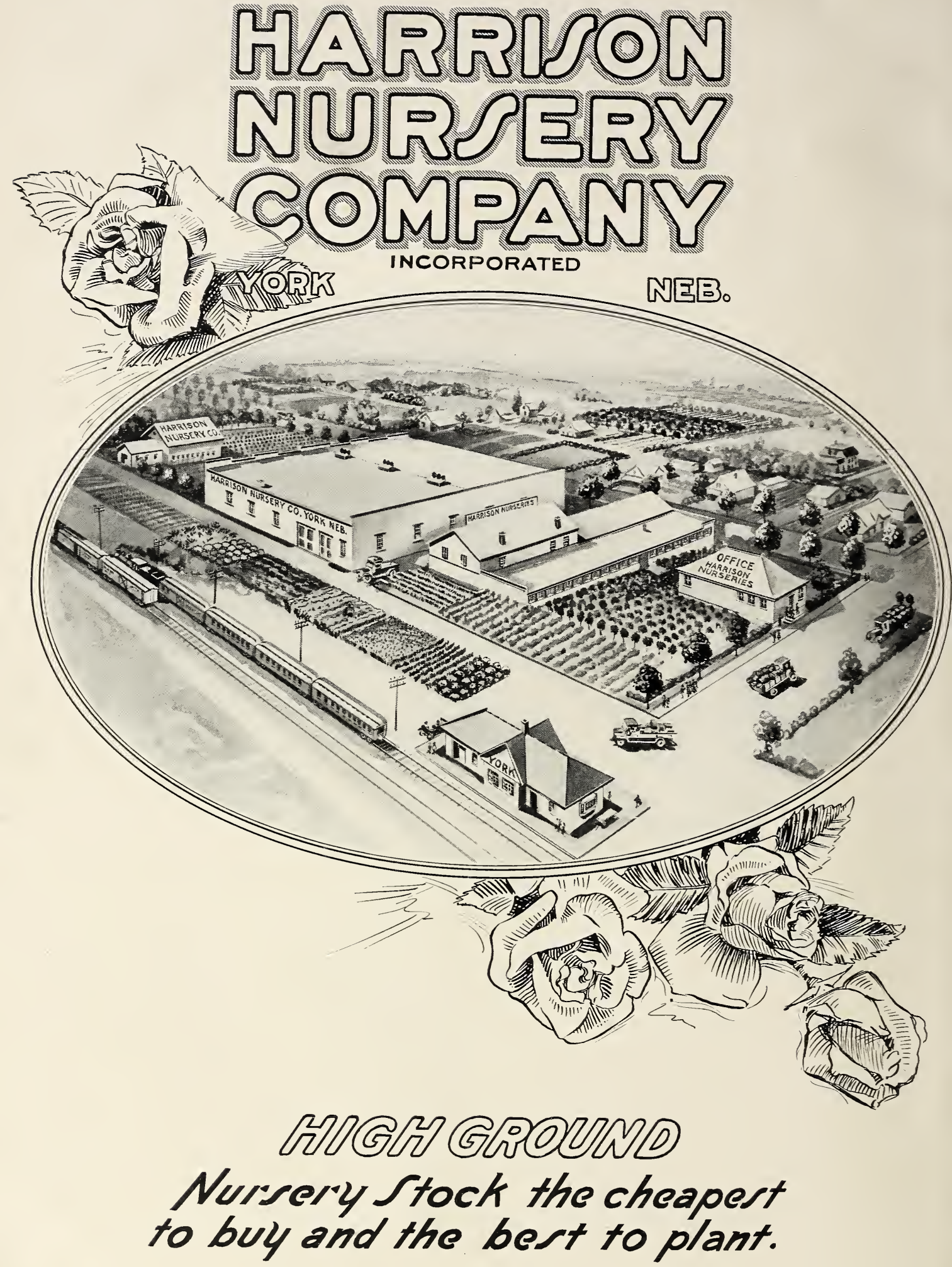

